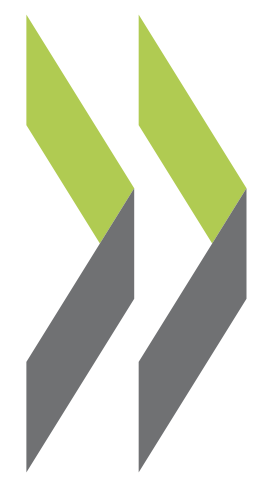

OECD Economics Department Working Papers No. 1684

\title{
Making digital transformation work for all in Chile
} Paula Garda 
ECONOMICS DEPARTMENT

\section{MAKING DIGITAL TRANSFORMATION WORK FOR ALL IN CHILE}

\section{ECONOMICS DEPARTMENT WORKING PAPERS No. 1684}

By Paula Garda

OECD Working Papers should not be reported as representing the official views of the OECD or of its member countries. The opinions expressed and arguments employed are those of the author(s).

Authorised for publication by Alvaro Pereira, Director, Country Studies Branch, Economics Department.

All Economics Department Working Papers are available at www.oecd.org/eco/workingpapers. 
OECD Working Papers should not be reported as representing the official views of the OECD or of its member countries. The opinions expressed and arguments employed are those of the author(s).

Working Papers describe preliminary results or research in progress by the author(s) and are published to stimulate discussion on a broad range of issues on which the OECD works.

Comments on Working Papers are welcomed, and may be sent to the Economics Department, OECD, 2 rue AndréPascal, 75775 Paris Cedex 16, France, or by e-mail to eco.contact@oecd.org.

All Economics Department Working Papers are available at www.oecd.org/eco/workingpapers.

This document and any map included herein are without prejudice to the status of or sovereignty over any territory, to the delimitation of international frontiers and boundaries and to the name of any territory, city orarea.

The statistical data for Israel are supplied by and under the responsibility of the relevant Israeli authorities. The use of such data by the OECD is without prejudice to the status of the Golan Heights, East Jerusalem and Israeli settlements in the West Bank under the terms of international law.

๑ OECD (2021)

You can copy, download or print OECD content for your own use, and you can include excerpts from OECD publications, databases and multimedia products in your own documents, presentations, blogs, websites and teaching materials, provided that suitable acknowledgment of OECD as source and copyright owner is given. Requests for commercial use and translation rights should be submitted to PubRights@oecd.org. 


\section{Abstract/Resumé}

\section{Making digital transformation work for all in Chile}

The sanitary crisis, created by the outbreak COVID-19, is accelerating Chile's digital transformation, which has seen a surge in e-learning, streaming, online shopping and marketing and teleworking. The digital transformation has the potential to revamp productivity and inclusiveness, although it comes with adoption barriers and transition costs. Connectivity has increased substantially in the last decades, and the country is ahead of the region. However, fixed high-speed broadband adoption, essential for the digital transformation, lags behind. Firms have started to adopt digital technologies but micro firms and SMEs are well behind. Rural areas have lower connectivity and many workers lack the skills to thrive in the digital world. Lowering the entry barriers in the communication sector and making regulations simpler and clearer would ease infrastructure deployment. Targeted policies for SMEs, such as development of sources of financing or specific programmes for adopting digital tools, would help them access and use digital tools, increasing productivity. Reforms to the innovation ecosystem, competition and the regulatory framework are also needed. To reap the benefits of digitalisation for all, it is necessary to continue investing in quality foundational skills, adult and lifelong learning and in high-skilled ICT specialists. Labour market policies need to be adapted to face the challenges and exploit the benefits posed by the digital transformation. An effective safety net would address possible labour market disruptions.

This Working Paper relates to the 2020 Economic Survey of Chile (http://www.oecd.org/economy/chileeconomic-snapshot/).

Key words: Chile, digital transformation, connectivity, productivity, skills, labour market JEL codes: D24, J24, J08, 128

\section{La transformation numérique au service de tous au Chili}

La crise sanitaire créée par l'épidémie de COVID-19 a accélèré la transformation numérique du Chili, qui a connu un essor de l'apprentissage en ligne, du streaming, des achats en ligne et du télétravail. La transformation numérique a le potentiel de relancer la productivité tout en réduisant les inégalités, mais elle s'accompagne d'obstacles à l'adoption et de coûts de transition. La connectivité a considérablement augmenté au cours des dernières décennies, et le Chili reste en avance sur la région. Cependant, l'adoption du haut débit fixe, essentiel à la transformation numérique, est en retard. Les entreprises ont commencé à adopter les technologies numériques, mais les micro-entreprises et les PME sont loin derrière. Les zones rurales sont aussi moins bien connectées et de nombreux travailleurs n'ont pas les compétences nécessaires pour s'épanouir dans le monde numérique. L'abaissement des barrières à l'entrée dans le secteur des communications et la simplification et la clarification des réglementations faciliteraient le déploiement des infrastructures. Des politiques ciblées pour les PME, telles que le développement de sources de financement ou de programmes spécifiques pour l'adoption d'outils numériques, les aideraient à accéder aux outils numériques et à en tirer pleinement partie, ce qui augmenterait la productivité. En outre, des réformes de l'écosystème de l'innovation, de la concurrence et du cadre réglementaire sont également nécessaires. Pour que tous puissent profiter des avantages lié à la numérisation, il est nécessaire de continuer à investir dans des compétences de base de qualité, dans l'éducation des adultes et la formation tout au long de la vie, ainsi que dans des spécialistes des TIC hautement qualifiés. Les politiques du marché du travail doivent aussi être adaptées pour relever les défis et exploiter les avantages de la transformation numérique. Notamment, un filet de sécurité efficace permettrait de faire face aux éventuelles perturbations du marché du travail qu'un tel processus pourrait engendré.

Ce Document de travail se rapporte à l'Étude économique du Chili 2020 (http://www.oecd.org/fr/economie/chili-en-un-coup-d-oeil/).

Mots clés: Chili, transformation numérique, connectivité, productivité, compétences, marché du travail Codes JEL: D24, J24, J08, 128 


\section{Table of contents}

\section{Making digital transformation work for all in Chile}

$\begin{array}{ll}\text { Promote connectivity and close the digital divide } & 7\end{array}$

Fostering infrastructure deployment to boost connectivity $\quad 7$

Closing digital divides $\quad 12$

Unlocking digital skills development and innovation capacity 15

Empower people with the right skills to succeed in a digital world $\quad 15$

$\begin{array}{ll}\text { Mobilise the private and public sector for digital innovation } & 23\end{array}$

Boosting business dynamism and the diffusion of knowledge in the digital era $\quad 27$

Boost adoption and diffusion of digital tools in firms, especially small and medium-sized $\quad 27$

$\begin{array}{ll}\text { Promote start-ups and young firms } & 33\end{array}$

$\begin{array}{ll}\text { Prepare for changes in international trade } & 36\end{array}$

Monitor competition to avoid the concentration pitfall 38

Preserving social cohesion and helping workers make the most out of a dynamic labour market 39

Digital transformation creates new jobs, but is also challenging $50 \%$ of the existing ones $\quad 39$

Promote job quality to cope with emerging forms of work 46

Improve social protection to leave no-one behind $\quad 49$

$\begin{array}{ll}\text { Chile is facing an important training challenge } & 50\end{array}$

Achieving sustainable and reliable digital infrastructures $\quad 54$

The momentum on digital government must continue $\quad 54$

Digital security capacity must be stepped-up $\quad 55$

Establish an interoperable privacy framework $\quad 56$

$\begin{array}{ll}\text { References } & 60\end{array}$

\section{Figures}

Figure 1. Increasing access to fixed broadband and reducing the regional disparities are the main challenges 9

$\begin{array}{lr}\text { Figure 2. Regulatory barriers on communications are high } & 10\end{array}$

$\begin{array}{ll}\text { Figure 3. There are wide disparities in Internet use } & 13\end{array}$

Figure 4. Access to Internet at home is widely determined by socio-economic variables 14

Figure 5. Digital adoption lags behind mainly in micro firms $\quad 15$

Figure 6. Chilean workers lack the skills to thrive in the digital era 16

Figure 7. Training teachers to be drivers of digital transformation should be a priority 18

Figure 8. Risks of digital transformation and extreme use of Internet should be avoided 19

Figure 9. ICT skills are increasingly demanded in Chile $\quad 20$

Figure 10. Chile is experiencing a clear shortage of ICT workers $\quad 21$

Figure 11. Bridging the innovation divide is necessary to increase productivity 23

Figure 12. R\&D and innovation spending remains low $\quad 24$

Figure 13. Public support for innovation has increased but remains limited $\quad 25$

Figure 14. Business collaboration should be strengthened $\quad 26$

$\begin{array}{lr}\text { Figure 15. The diffusion of digital tools needs a boost } & 28\end{array}$

Figure 16. Digital adoption leads to higher firm level productivity $\quad 29$

Figure 17. E-commerce in Chile has been growing at a fast pace $\quad 30$ 
Figure 18. Competitive pressures remain low and the regulatory burden is high 32

Figure 19. Chile has room to increase the number of Fintech start-ups $\quad 35$

Figure 20. The development of venture capital has stalled in Chile $\quad 35$

Figure 21. Digital Services Trade Restrictiveness is high $\quad 37$

Figure 22. The interoperability of national regulatory frameworks with the region could improve 38

Figure 23. Employment in digital-intensive sectors remains low in Chile 40

Figure 24. The Chilean labour market shows signs of polarisation 41

Figure 25. More than half of jobs are at risk of automation, affecting more low and middle-classes 42

Figure 26. Employment in routine manual occupations and those with high risk of automation has decreased

in the last decade $\quad 43$

Figure 27. Automation risk and labour market transitions in Chile 44

Figure 28. Artificial intelligence and labour market transitions in Chile 44

Figure 29. Automation risk leads to lower wages for the low-income, but artificial intelligence has a positive impact

Figure 30. Online platforms have increased at a fast pace in Chile 46

Figure 31. Self-employment, temporary and informal jobs are prevalent in Chile 47

Figure 32. Participation in training is high in Chile $\quad 51$

Figure 33. Most vulnerable workers receive less training $\quad 52$

Figure 34. The uptake of digital government services remains low $\quad 55$

$\begin{array}{lr}\text { Figure 35. Cybersecurity capacities are lacking } & 56\end{array}$

$\begin{array}{ll}\text { Figure 36. Data privacy violations are the highest in the OECD } & 57\end{array}$

\section{Boxes}

Box 1. Ongoing projects to extend fibre cables throughout Chile $\quad 8$

Box 2. The divide in household Internet usage in Chile $\quad 14$

Box 3. Digitalisation is already having a positive impact on Chilean firms' productivity 29

Box 4. Is the impact of digital technologies already visible in the Chilean labour market?

Box 5. The impact of digital transformation on wages in Chile $\quad 45$ 


\title{
Making digital transformation work for all
} in Chile

\author{
By Paula Garda ${ }^{1}$
}

Digital transformation can boost productivity growth and living standards. Digital technologies are transforming the way business, households and governments interact, transact, buy and sell. The trends that are pushing digital transformation in economies and societies are, for example, the Internet of Things, Artificial Intelligence, cloud computing, automated supplier, blockchain or online platforms.

Chile has made great progress in digitalisation and is leading in the region. The country has been able to lead also worldwide in some areas of hard sciences, such as astronomy. Authorities are also working to become a data observatory and has developed several open public data sets. Moreover, Chile has pioneered the signing of a Digital Economy Partnership Agreement with Singapore and New Zealand to help exporters and SMEs take advantage of opportunities from digital trade. Based on this experience, Chile has a great potential to use and exploit digital transformation to boost productivity and well-being.

Despite the ongoing digital transformation, productivity has been declining in Chile. Like in other OECD countries, this may, at least in part, reflect slow digital technology diffusion, which could offset other restraints on productivity growth. Other factors affecting the productivity slowdown have been declining commodity prices, the fall of ore grades, and an over-exploitation of fisheries, while the adoption of new technologies remains low in many firms (OECD, 2018[1]). The adoption of digital technologies has been concentrated among the largest and most productive firms, that benefit from innovation and organisational capital. If the numerous micro and small firms are to catch up with large firms, adoption and use of digital technologies needs to speed up.

The digital transformation can bring many new opportunities for workers and improvements in job-quality. There are also fears that digital technologies and automation could potentially displace some workers or, at least, transform the tasks they are doing. Adjustment costs may be significant, and are more likely to be borne by the low-skilled and low and middle-income households, who may lack the skills needed to thrive in the digital era. This, together with an increase in the demand of higher skill professionals, could lead to higher inequality and more informal or low-quality jobs when vulnerable workers do not possess the skills needed.

The sanitary crisis, created by the COVID-19 outbreak, is accelerating the digital transformation of the country. As a result of the pandemic, many firms had to adopt several digital technologies, such as video conferencing, document sharing, cloud solutions, information security, or online selling and buying, to keep their operations running. Employers have been pushed to work with remote teams and employees have started to learn to interact with colleagues virtually and manage their time online from home. This is resulting in a steep learning curve. Authorities approved a telework act that entitles workers to provide their services from home or any other place other than the establishments of the firm, maintaining the same

1. Acknowledgments: Paula Garda is Economist in the OECD Economics department. The author would like to thank Alvaro Pereira, Isabell Koske, Patrick Lenain, Piritta Sorsa, Nicolas Ruiz and Muge Adalet McGowan for useful comments and suggestions. The paper has also benefited from comments by members of the OECD Economic and Development Review Committee. This work also benefits from work done with Mauricio Hitschfeld and Clara Marköö, while doing their internship at the OECD Economics Department. The author is also grateful to Marnix Dek for statistical assistance, and Carolina Gonzalez and Karimatou Diallo for editorial assistance. 
working conditions as on site workers. A proof that the pandemic is changing and accelerating the digital transformation of the economy is the share of citizens using the digital identity that has stepped up to $40 \%$ in 2020. The Government is also using digital applications to help in the containment of the propagation of the virus, notably through online education and the virtual police station, an application by which all citizens need to ask for permissions to go out during mandatory quarantines.

However, inequities in digital adoption and digital skills, precluding teleworking, online selling, distance learning, or even asking for permission to go out during quarantines, could deepen the already high inequality of opportunities for workers and firms. Indeed, while around $20 \%$ of workers have high possibilities of teleworking, the likelihood decreases sharply for workers without tertiary education and with lower levels of numeracy and literacy skills (Espinoza and Reznikova, 2020 ${ }_{[2]}$ ). This chapter presents an analysis of the starting point, before the pandemic, of firms, households, workers and the government. It analyses the policies needed to accelerate the digital transformation while at the same time lowering possible transitions costs and intrinsic inequities.

As digital transformation has widespread and complex effects across the economy and society, a holistic and co-ordinated policy approach is essential. The OECD Going Digital Integrated Policy Framework helps governments and stakeholders to develop an integrated approach to policy making in the digital age and to shape policies for an inclusive digital future (OECD, 2020[3]). The framework includes seven interrelated policy dimensions: 1) access to communications infrastructures, services and data; 2) effective use of digital technologies and data; 3) digital and data-driven innovation; 4) quality jobs for all; 5) social prosperity and inclusion; 6) trust in the digital age; and 7) market openness in digital business environments. Transversal policy issues (e.g. skills, digital government, SMEs and data) cut across several policy dimensions. This chapter discusses some of the key aspects of each of the framework's policy dimensions and transversal policy issues for Chile. It builds on many of the key policy recommendations from the OECD's Going Digital project (OECD, 2019[4]).

The chapter argues that to boost productivity through the digital transformation and leave no one behind, a comprehensive set of reforms is needed. To take full advantage of the digital transformation, Chile must further extend broadband coverage and use, including through a comprehensive package of regulatory and governance reforms, and also invest in complementary assets. In particular, policies should empower everyone with a mix of skills to thrive and trust in a digital world; boost adoption and diffusion of digital tools to drive productivity growth in firms, in particular small and medium-sized enterprises, boost the innovation capacity of firms; and make digital government services more user-centred.

\section{Promote connectivity and close the digital divide}

\section{Fostering infrastructure deployment to boost connectivity}

In recent years, the telecommunications sector in Chile has experienced rapid and impressive advances. In 2010, Chile was the first OECD country to legislate in favour of network neutrality and prohibit the blocking of unreasonable discrimination of services. Between 2010 and 2018, Chile experienced one of the most rapid adoption of mobile broadband in the OECD, with a 10-fold increase in subscriptions to 92.4 per 100 inhabitants by June 2019 (Figure 1), although from low levels. The share of Chilean households with a fixed or mobile broadband connection is similar to the OECD average of $87.5 \%$. Business broadband connectivity is also high at $89.6 \%$, according to the first Chilean ICT survey conducted in 2019.

One of the biggest connectivity challenges of the country is the low fixed broadband penetration. Even if Chile has greatly advanced in internet connectivity with one of the highest rates of annual growth of fibre subscriptions across OECD, at $66.5 \%$ between 2018 and 2019, the country lags well behind the OECD average in fixed broadband penetration and high-speed connection (Figure 1, Panels $A$ and B). The deployment of high-speed fixed networks is not only important to increase fixed broadband penetration in 


\section{8 | ECO/WKP(2021)35}

the country, but also for the newer generation of mobile networks, with $5 \mathrm{G}$ networks relying mostly on fibre backbones. Connections to fibre optic, the most rapid broadband connection, is low with only $25 \%$ of total broadband connections and $50 \%$ of these connections concentrated in the Región Metropolitana, according to SUBTEL data. Expanding quality broadband to rural and remote areas will be also a key challenge as differences in coverage between urban and rural areas are large (Figure 1, Panel C). This is particularly true for fixed connections in which coverage in rural areas is $21 \%$ of households, while in urban areas accounts for more than $60 \%$ of households.

Improving the existing legal, regulatory and governance frameworks that incentivise investment in highspeed broadband networks will be key for Chile's digital transformation. Lowering entry barriers and easing both fixed and mobile network deployment is essential to increase the access and use of high-speed broadband services at competitive prices.

The Government's agenda (2018-2022) goes in the right direction. It includes plans to foster investment, increase competition by eliminating entry barriers for new operators and better regulation, a comprehensive plan on investment in communication infrastructure and providing communication services for the most vulnerable. As a result, in recent years, especially the mobile communication market has become more competitive with the market entry of a challenger firm, and several measures such as the introduction of number portability. In addition, SERNAC, Chile's National Consumer Agency created a webpage "Me quiero Salir" (I want to break free) for any consumer who wants to cancel a contract can now do so online, making easier to switch internet providers. Prices for mobile broadband services have also decreased. In terms of international traffic exchange, the country is enhancing its capacity through new submarine cables (Box 1). The government agenda also includes a "national digital highway", aiming at doubling the current fibre backbone capacity, from 18 to 36 thousand kilometres over the next three years.

\section{Box 1. Ongoing projects to extend fibre cables throughout Chile}

FOA (Fibra Optica Austral): Submarine cable from Puerto Montt to Puerto Williams, in the south of Chile and has a maximum capacity of transmission of 16 Tbps (USD 100 million in investments);

Cable Prat: Submarine cable of 3500 kilometers, between Arica and Puerto Montt, landing in another 5 cities on the way and has a maximum capacity of transmission of 4 Tbps (USD 80 million in investments);

Curie Optical Fiber (Google): International submarine cable of 10500 kilometres, from Valparaíso to Los Angeles,California (USD 150 million in investments);

South Pacfic Subsea Cable (America Movil): Submarine cable of 7200 kilometers from the San Jose Port, Guatemala, to Valparaíso landing in Ecuador and Peru, it has a total capacity of 108 Tbps (USD 100 million in investments);

Transpacific Cable (under evaluation): Cable to connect South America and Asia.

Source: Ministry of Economy of Chile

There are also plans to rollout $5 \mathrm{G}$ technology, which will demand significant investment in infrastructure, including in new towers capable of providing more capacity, and bigger data centres running on efficient energy. 5G technology can act as a 'leapfrog' technology, allowing to fast-track digital development in rural areas. This would require more fibre deployment and new last mile connectivity solutions to make sure people have potential access to faster, better quality network. Chile's public policy for the development of $5 G$ is the result of six fundamental principles: neutrality of networks; technological neutrality; open access; free foreign investment; free and fast licensing regime; and finally alignment with the national cybersecurity policy. The first bidding for rolling out $5 \mathrm{G}$ began in 2020 and the auction will take place at the beginning of 2021. 
Figure 1. Increasing access to fixed broadband and reducing the regional disparities are the main challenges

\section{A. Broadband connections per 100 inhabitants, June 2019}

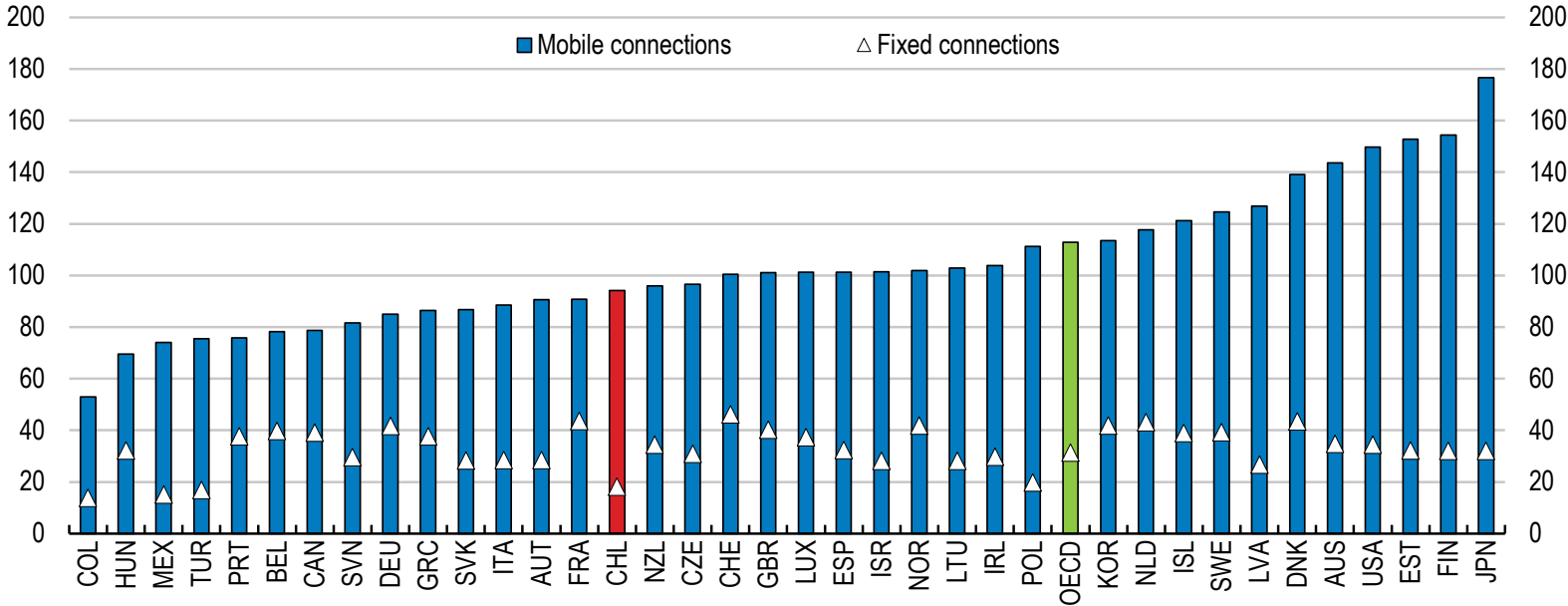

B. Fixed broadband subscriptions per 100 inhabitants, per speed tiers, June 2019

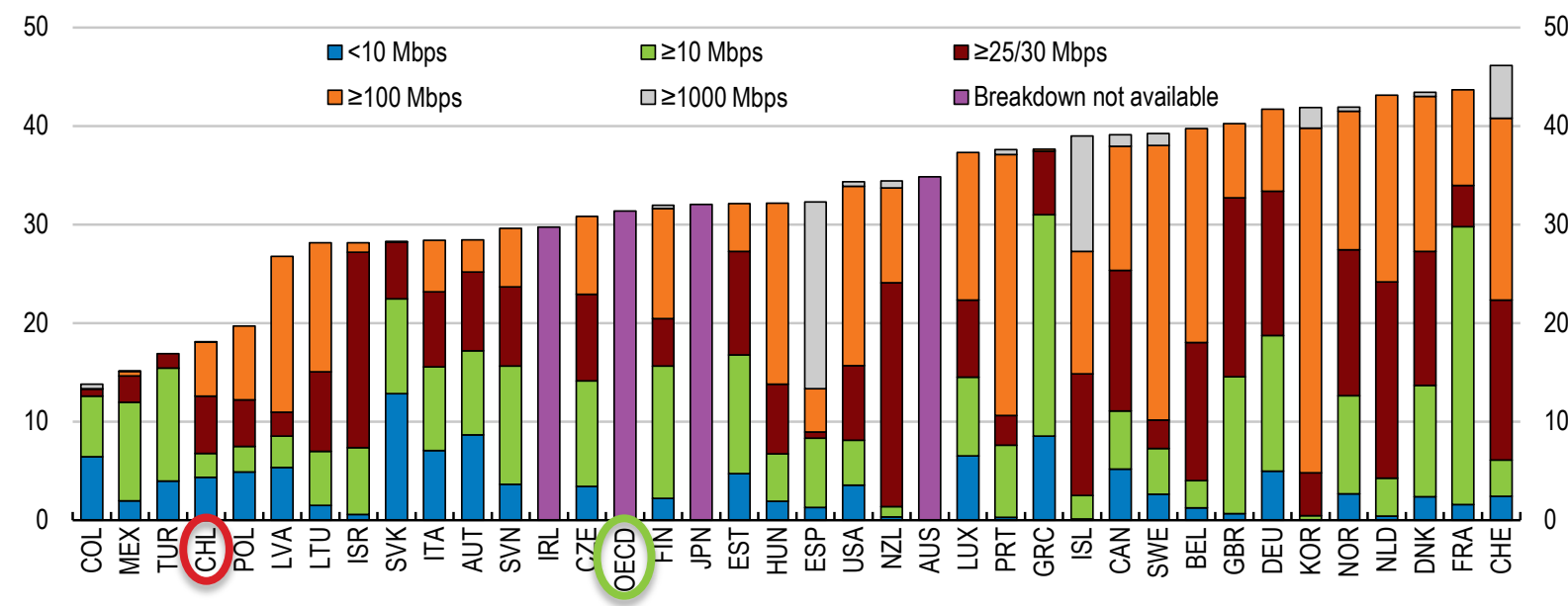

C. Fixed and mobile broadband coverage in urban and rural areas, 2019 or latest year available

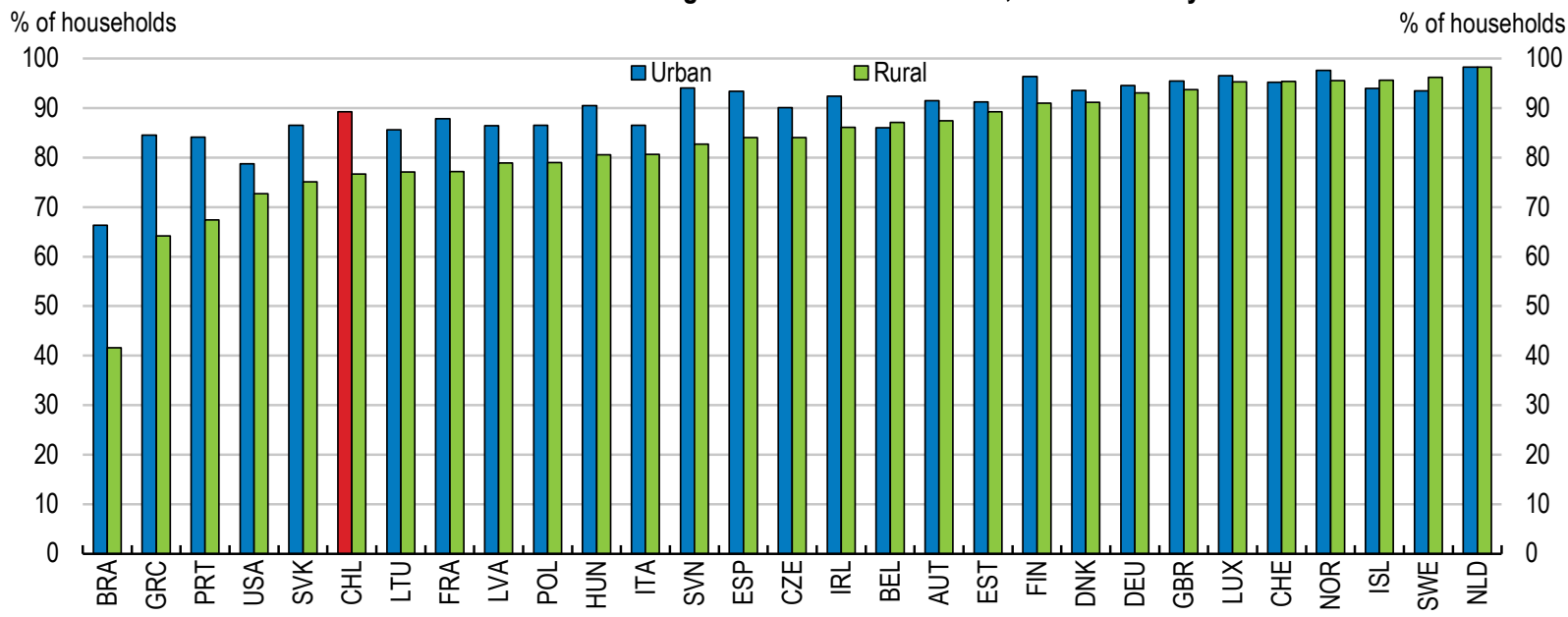

Note: In Panel $\mathrm{C}$, urban areas refer to large urban areas.

Source: OECD, Broadband Portal, www.oecd.org/sti/broadband/oecdbroadbandportal.htm; OECD ICT Access and Usage by Households and Individuals database. 
A recent OECD policy note analyses in detail the communications sector in Chile. It describes in detail, the policy recommendations and actions to take to ease market entry, boost infrastructure deployment, improve the efficiency of spectrum management and strengthen the governance of the sector (OECD, $\left.2021_{[5]}\right)$, all of which are key to boost connectivity. Some of the recommendations will be summarised below.

Boosting infrastructure deployment will hinge on lowering the existing high entry barriers (Figure 2) and easing the deployment of fixed and mobile communication infrastructure. Lower entry barriers and a contestable communication market could be achieved by eliminating the existing regulation for concessions, which is burdensome for operators (OECD, 2021 $\left.{ }_{[5]}\right)$. It is necessary to adopt a single licensing regime whereby operators are authorized to engage in all communication services throughout the entire Chilean territory. This would encourage potential operators to enter the market and engage in infrastructure deployment, thus reducing barriers to entry. Incumbent operators would also be encouraged to engage in new communication services and prices could be further reduced although from relatively low levels (ITU, $\left.2020_{[6]}\right)$.

\section{Figure 2. Regulatory barriers on communications are high}

Product market regulation index for e-communications, 2018

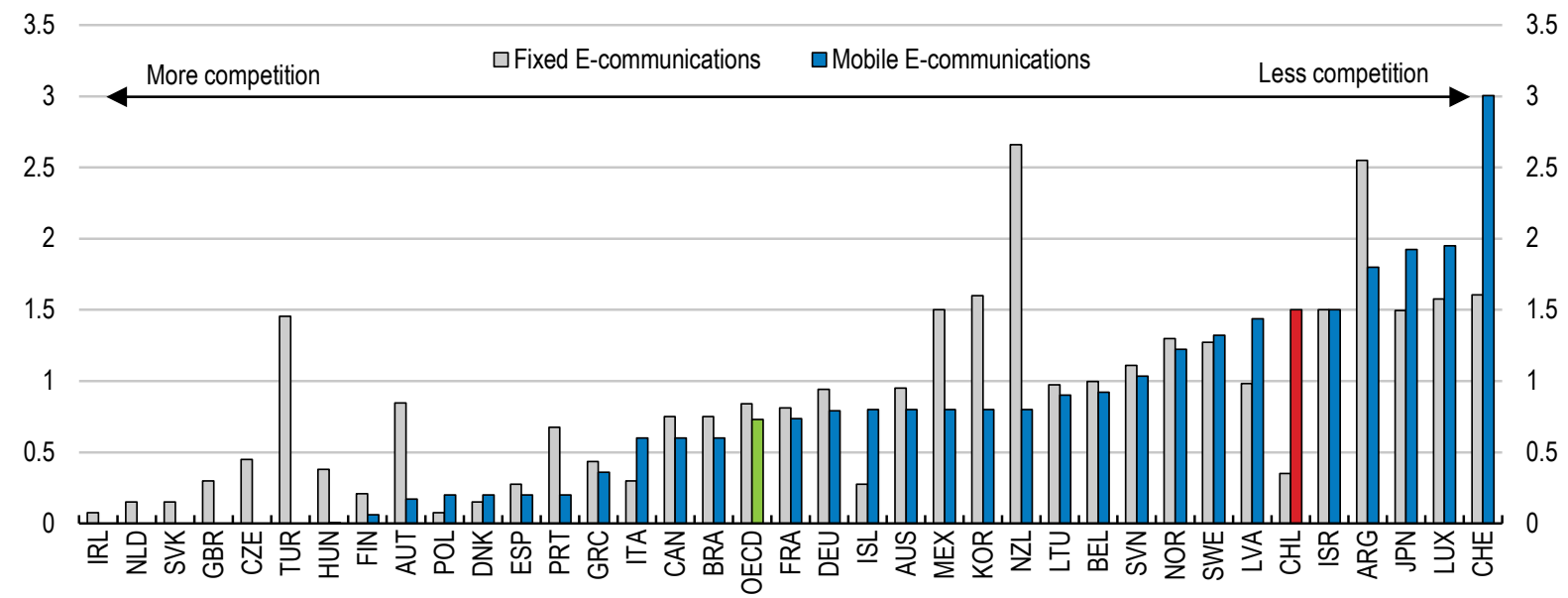

Note: E-communications include both voice services and data services.

Source: OECD, 2018 PMR database.

StatLink ज्ञाs https://doi.org/10.1787/888934193763

One of the main barriers operators face in the sector is the existence of various regulations (and regulators), acting as a barrier for infrastructure deployment and making it hard for new operators to enter the Chilean market. Although regulations to grant permits for deployment of passive infrastructure are at the national level, the actual power of authorisation of deployment is the responsibility of municipalities. Municipalities, in turn, have different and unique legal frameworks that are not necessarily harmonised. Streamlining the various regulations at different government levels and a unique and central entity providing guidelines and standards for communication infrastructure deployment would lower the barriers to entry in the market (OECD, 2021 $1_{[5]}$ ). An already existing platform (SUPER) (on which more below) could be used as the platform to achieve this.

To boost infrastructure deployment, Chile would greatly benefit from a National Information Transfer System through which actors and public entities can share information regarding preferable zones for infrastructure deployment. The Government agenda for economic revival (Agenda de Reimpulso Económico) of end of 2019 proposes that the Undersecretary of Telecommunications in agreement with the public companies should put out to tender public spaces to telecommunications companies for the installation of the necessary telecommunications infrastructure to deploy $5 \mathrm{G}$ technology. Furthermore, the 
Antennas Law and other relevant laws could include an obligation for Municipal Works Directorates to share cadastre information about the preferential zones for infrastructure deployment with SUBTEL and other national authorities periodically. This would increase operators' incentives to verify preferential areas for infrastructure deployment throughout the national territory and rural zones.

Provisions for passive infrastructure sharing and the establishment of clear criteria regulating rights of way are needed to boost infrastructure deployment in the sector. Current regulation is cumbersome for the obtainment of permits, and operators (particularly incoming ones) face serious difficulties in deploying their infrastructure and networks. Chile could benefit greatly from a revision of its heterogeneous rules for the obtainment of rights of way and requiring dominant players to share their infrastructure with competitors. Creating an infrastructure sharing system between sectors that contains a prior regulation for the use of poles, pipelines, cables, and other infrastructure of the electrical, aqueduct, and sewer sectors would greatly benefit the country (OECD, 2021 $\left[{ }_{[5]}\right)$. The European Union Broadband Cost Reduction Directive (2014/61/EU) could provide some guidance on provisions that allow communication network operators to access other utility networks.

Infrastructure deployment for rural and remote areas will be key for an inclusive digital transformation. However, there is no clear universal-access obligation for operators. Hence, there is no incentive to undertake public bids to provide communication services in rural and remote areas. The Telecommunications Development Fund was created to promote the coverage of telecommunications services, preferably in rural areas and urban areas with low income households. The projects, eligible for subsidies, are based on connectivity requirements or demands made by communication services concessionaires, municipalities, neighbourhood councils, and other social or community organisations or third parties (OECD, 2021[5]). In March 2020, the government launched the tender for a telecommunications connectivity project benefiting rural areas to improve connectivity and provide a wider range of Internet and mobile phone services.

An efficient spectrum management usually translates into better communication infrastructure and investment, adequate coverage for the population, higher service quality and lower prices (OECD/IDB, $\left.2016_{[7]}\right)$. In 2018, the Supreme Court declared as anticompetitive the holding of spectrum in the $700 \mathrm{MHz}$ band of the three biggest telecoms following a call for tenders in 2013, which have not respected the 60 $\mathrm{MHz}$ limit imposed in 2009. This generated severe challenges for the latest spectrum assignments and several players had to return spectrum licences. This has led to uncertainty in the market, including with respect to future assignments. It is important to establish a strong spectrum policy to provide clear and transparent targets that looks at both licensed and unlicensed spectrums. SUBTEL has proposed a new spectrum cap by operator in each band, which has been ratified by the Supreme Court and the bidding was announced in August 2020. Technical and economic criteria should be clearly defined, to contribute for the determination to reasonable obligations for the assignees in the future spectrum assignment processes for mobile telecommunication services. Determining the priority sectors for digital transformation, to be addressed at the national and regional level and considered in future spectrum assignment processes would also help boost deployment of services in all regions of the country, including areas without mobile service coverage (OECD, 2021 $\left.{ }_{[5]}\right)$.

Chile would benefit from establishing a dedicated economic and technical regulator independent from the executive, in line with OECD policy recommendations (OECD, 2021[5]). Today, SUBTEL, the Sub secretariat of Telecommunications, is a centralised organism of the Ministry of Transport and Telecommunications and as such, its resourcing framework differs from the requirements of a stable, independent and technical regulator for the communication sector, in line with OECD policy recommendations and practice across OECD member countries. An example of a reform in this area is Mexico in 2013 that created the Federal Telecommunications Institute as an autonomous public agency, independent in its decisions and function, with its legal status and resources, for the purpose of regulating and promoting competition and efficient development of the communication and broadcasting sectors. 
Robust and transparent governance of Chile's communication regulator will be key to assuring the efficiency of the sector, in particular in deploying new technologies and infrastructures, such as future 5G.

\section{Closing digital divides}

With the surge of the COVID-19 pandemic access to the internet has become more important than ever, as it means access to education and work. Although average internet usage is at the same levels as OECD countries, there are still clear disparities (Figure 3). As a result, many people are at risk of being left behind, with $35 \%$ of those without Internet access reporting high costs as the main barrier for not accessing the Internet, and 25\% declaring not having the skills to use the Internet (Subtel, $2017_{[8]}$ ).

Observed differences in Internet use reflect the inequalities in the Chilean society, with education being the most important factor (Box 2). Internet use by the highly educated is nearing saturation levels, while use of the Chile's large cohort with lower education is below OECD average (Figure 3, panel B). Age also plays an important role in Internet use, with old-aged being less likely to use the Internet. Labour market determinants, such as being unemployed or inactive, having an informal or temporary job, negatively affect the probability of connection to the Internet. This is worrying, since distance learning and online job search would be particularly important for these type of workers. Household income also plays an important role in determining Internet usage, with Chile showing an 11 percentage points gap between high and low income. The rural-urban divide is also important, with rural dwellers having 10-percentage points lower probability of using the Internet. This gap is even more important for broadband Internet, with a 30percentage points gap. However, Chile has a small gender and indigenous gap in Internet use.

Regarding firms, although there has been great progress in digitalisation among firms of all sizes and Chile is well ahead in the region, there is still a wide divide between large firms and SMES. Large firms innovate and adopt digital technologies while the more numerous micro and small ones struggle to keep pace with digitalisation (Figure 5). This could be creating a divide between those working for large firms and the others, in terms of employment quality and wages. This might be a source of earnings inequality and put the middle class, which is usually employed in micro and small firms, under pressure.

Chile needs measures to close the existing digital divide. Providing pathways to Internet access, computer access and digital learning opportunities for all should be a priority. Chile has recently put in place policies to increase affordability and boost Internet adoption for households, firms and the government, as evident from the digital agenda of the Government. This agenda has as main objectives guaranteeing minimum levels of speed and quality of Internet access, the reduction of tariffs for all mobile phone users, extending coverage to remote areas, and connecting to Internet all the public educational establishments. 
Figure 3. There are wide disparities in Internet use

Internet use in the past 12 months as a percentage of reference population
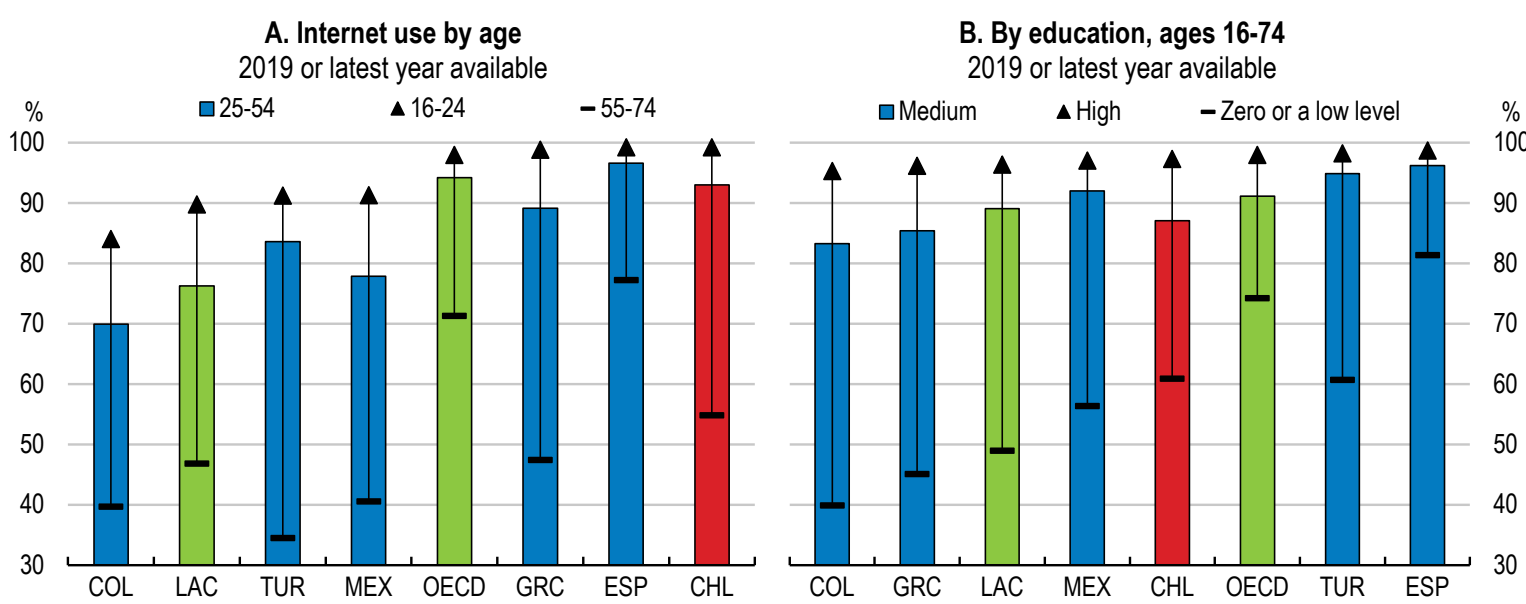

C. Gender, ages 16-76

2019 or latest year available

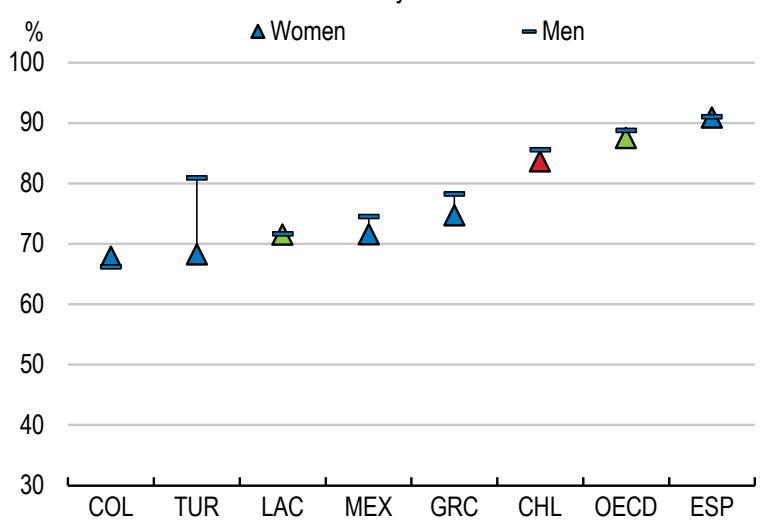

D. Income group 2019 or latest year available

$\Delta$ Top $25 \%$

- Bottom $25 \%$ $\%$

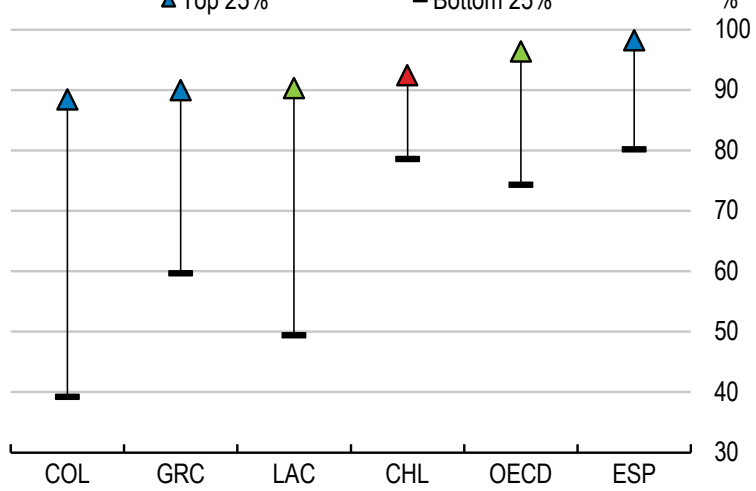

Note: In Panel B, the level of education refers to the highest level of education attained: at most lower secondary (ISCED 0,1 or 2$)=Z$ Zero or a low level; upper or post-secondary, but not tertiary (ISCED 3 or 4$)=$ Medium; or tertiary (ISCED 5 or above) $=$ High. OECD refers to an unweighted average of latest available data. LAC refers to an unweighted average of Brazil, Colombia and Mexico in Panels A, B and C. LAC refers to an unweighted average of Brazil and Colombia in Panel $D$.

Source: OECD, ICT Access and Usage by Households and Individuals database. 


\section{Box 2. The divide in household Internet usage in Chile}

Analysis based on microdata from Chilean household survey (CASEN) for the year 2017 allows gauging the drivers in the divide for Internet access. A model for the household probability of having a subscription to the Internet (fixed or mobile broadband) is used. It includes individual characteristics (such as, age, gender, education, indigenous), household characteristics (household income, region and if living in a rural or urban region) and labour market variables (informality, unstable job, low earnings).

The estimated probability of being connected to the Internet at home for an indigenous inactive woman aged 60-75 years old, with low education, living in a rural area and in a household with low income, is practically zero (Figure 4). If the same woman would move to an urban area, the probability of using the Internet at home would increase by around 15 percentage points. If this same woman would be middleaged, the probability would be almost $20 \%$, and if the woman would have achieved higher education the probability would jump to above $60 \%$. Labour market variables, even after controlling by household income, are also important.

\section{Figure 4. Access to Internet at home is widely determined by socio-economic variables}

Estimated probability from the baseline with incremental changes in characteristics $\%$

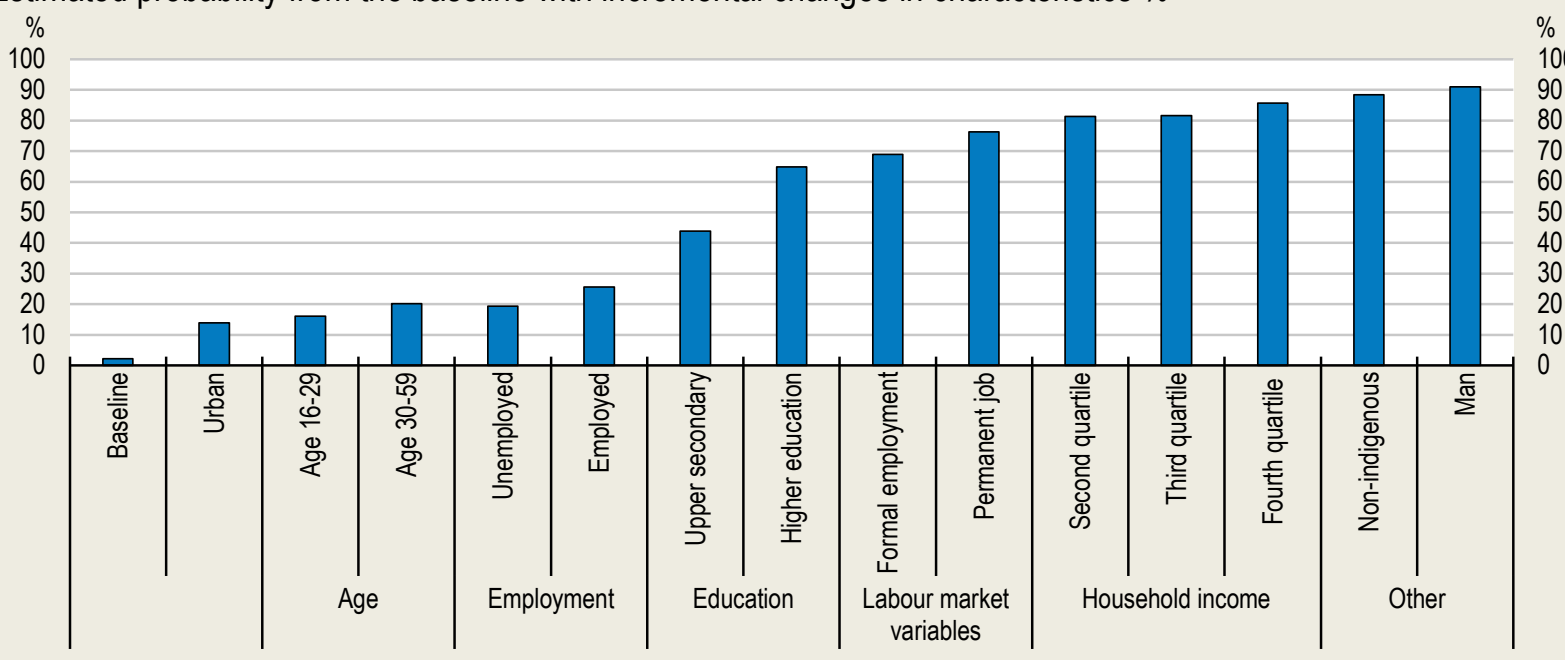

Note: The baseline refers to a woman aged 60-75, indigenous, with low education (with low secondary or lower), inactive, living in a household within low household income (first quartile) and in the rural area. The bar shows the estimated average probability of being connected at home to Internet (broadband or mobile). Estimates are obtained through a probit estimation controlling for age, gender, education, indigenous, rural area, per-capita household income, and regional effects. Informality is defined as not contributing to the pension system. The stability of the job is defined as having a temporary contract. Standard errors are clustered at regional level.

Source: OECD calculations using Household survey data (CASEN, 2017). 
Figure 5. Digital adoption lags behind mainly in micro firms

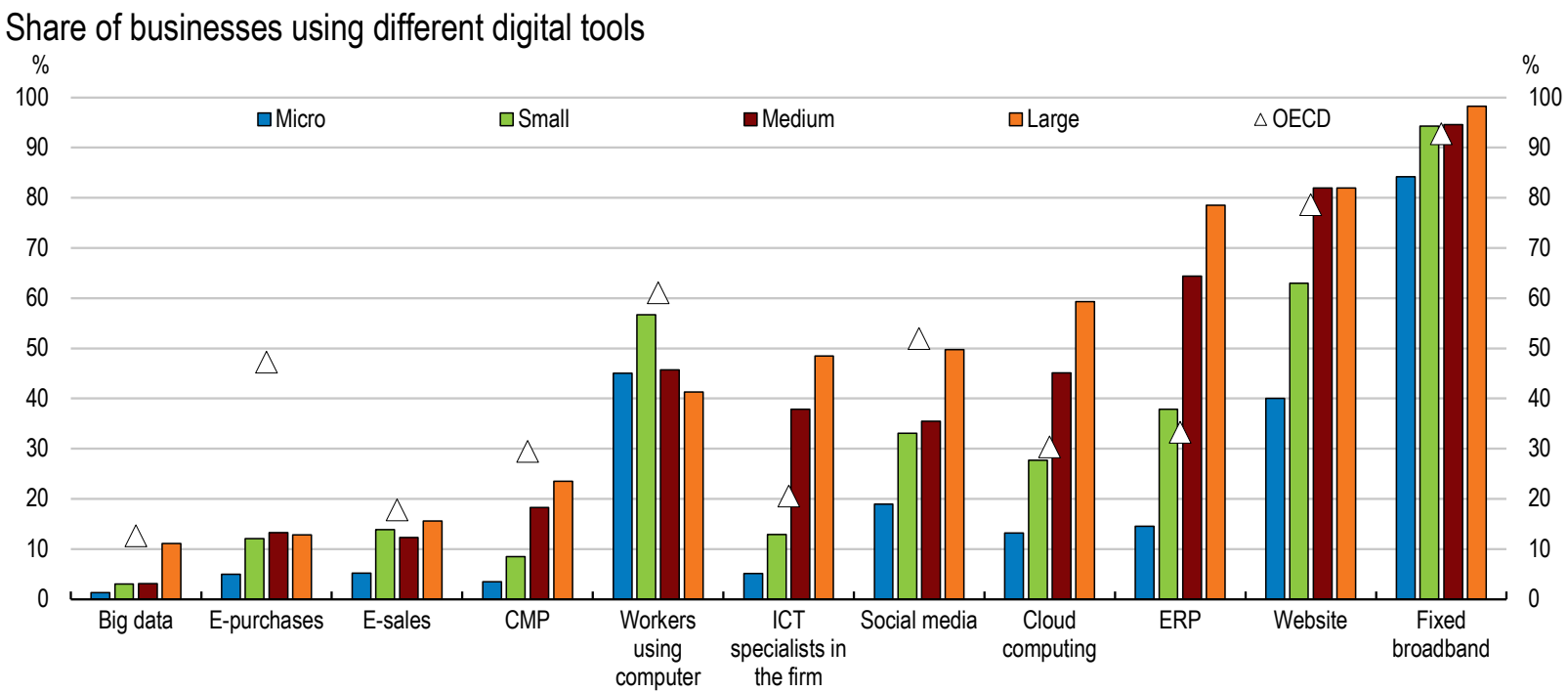

Note: Data refer to 2018 for Chile and 2019 or latest year available for the other countries. LAC refers to the unweighted average of Brazil, Colombia and Mexico. OECD refers to an unweighted average of 34 member countries. Size is calculated on the basis of numbers of persons employed. Micro firms are those employing less than 10 workers. SMEs are defined as businesses with 10 to 249 employees and large firms as businesses with 250 employees or more. The stratification in the Chile innovation survey is done by sales and hence it could be not statistically representative by number of employees.

Source: For Chile, data come from the ICT survey 2019, Ministry of Economy. Data for the other countries come from OECD, ICT Access and Usage by Businesses database.

StatLink ज्ञाs https://doi.org/10.1787/888934193820

\section{Unlocking digital skills development and innovation capacity}

\section{Empower people with the right skills to succeed in a digital world}

Ensuring that everyone has the right skills for an increasingly digital economy is essential to promote inclusive labour markets, spur innovation, productivity and growth. Thriving the digital transformation requires several types of skills. For example, ICT problem-solving skills, such as the ability to navigate technology-rich environments and use the Internet in a variety of ways. Specialised ICT skills for workers who drive innovation and the functioning of the digital eco-system. Also, ICT complementary "soft" skills, such as leadership, communication, management and teamwork skills, on top of good foundation skills, such as solid literary, numeracy and problem solving skills (OECD, 2018[9]; OECD, 2016 $\left.{ }_{[10]}\right)$. Providing everyone with the right mix of skills will hinge on updating education, training contents, teaching methods, while upgrading the institutional capacity, and streamlining the norms governing the education and training system.

Digitalisation calls for all workers to have a relatively high minimum level of ICT skills, even those in lowskilled jobs. This has become evident as the fight against the COVID-19 pandemic forced schools and universities closures. In this context, Chile has accelerated and mobilised different forms of online education and digital education resources. However, both teachers and students need to be very familiar with these technologies and their use in order for them to be effective. Pre-existing unequal digital skills among students, parents and teachers could determine unequal long-term consequences of the pandemic. 


\section{Enhancing foundational skills and developing digital skills in schools}

Individuals in Chile often lack the foundation skills necessary to flourish in a digital world (Figure 6). Quality education and better access to education have been important objectives for the authorities in Chile, as reflected in recent educational reforms. More efforts to ensure access to high-quality initial education for everyone will be key, as it is a precondition for developing these skills to benefit from digitalisation, and hence has the potential to foster an inclusive society and would help reduce the digital divide.

\section{Figure 6. Chilean workers lack the skills to thrive in the digital era}

Share of youth (16-24), prime age adults (25-54) and older people (55-65) lacking basic skills, percentage

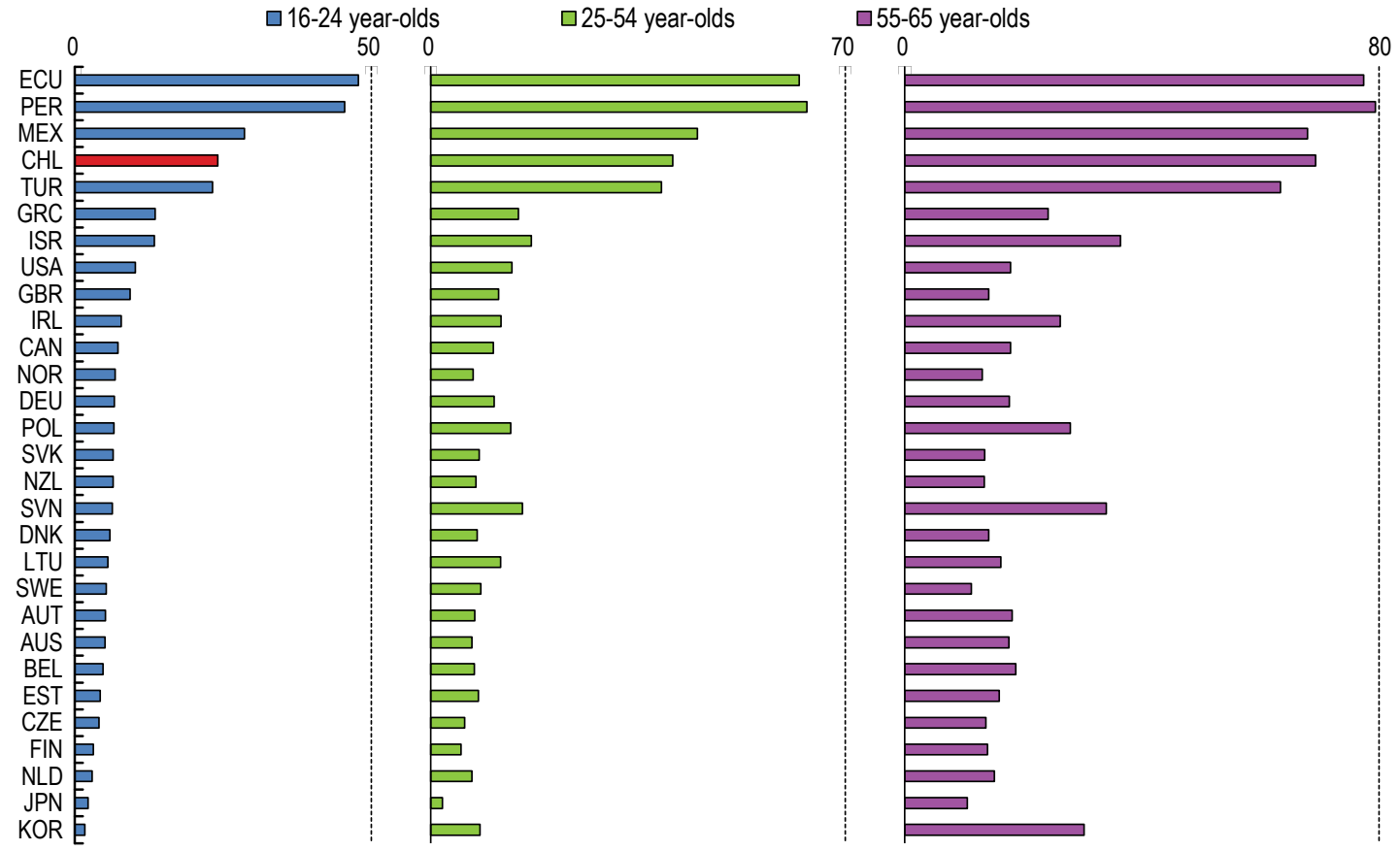

Note: Individuals lacking basic skills score at most Level 1 (inclusive) in literacy and numeracy and at most Below Level 1 (inclusive) in problem solving (including failing ICT core and having no computer experience). Chile, Greece, Israel, Lithuania, New Zealand, Slovenia and Turkey: Year of reference 2015. Ecuador, Mexico, Peru and United States: Year of reference 2017. All other countries: Year of reference 2012. Data for Belgium refer only to Flanders and data for the United Kingdom refer to England and Northern Ireland jointly.

Source: OECD calculations based on the Survey of Adult Skills (PIAAC), www.oecd.org/skills/piaac/publicdataandanalysis using the methodology of the OECD Skills Outlook 2019.

Improving the digital skills of individuals is an important component of the Government's agenda. The authorities have put in place programmes to support the development of a wide range of digital skills, from software development to basic digital literacy, such as I connect to learn (Me Conecto Para Aprender) and I choose my PC (Yo elijo mi PC). These programmes deliver a laptop computer (including mobile broadband for one year) to each student in all public schools and vulnerable and good students in subsidized schools during the 7th year of basic education. These programmes have been extended in March 2020 with the programme ICT scholarship (Becas TIC). The initiative "Programme your Ideas" (Programa tus Ideas) seeks to bring the programming of mobile applications closer to the children and the young population. 
Chile would benefit from a revised national curriculum to reinforce digital skills. The national curriculum already includes the teaching of computer skills, but Chile would benefit further from including the teaching of ICT skills in a transversal way. The curriculum should emphasise the development of computational thinking, coding skills, and creative expression through software, including the use and development of ICT skills in different knowledge areas. For example in Sweden, education for ICT is integrated in curricula as a learning outcome: "every pupil, on completing primary and lower secondary school, must be able to use modern technology as a tool for knowledge-seeking, communication, creation and learning". The new Schools Act from 2011 introduced new/revised syllabuses and a new curriculum for Swedish primary and lower secondary schools. The upper secondary school has also acquired new syllabuses, and a new qualification descriptor has been introduced for teacher and preschool teacher training programmes. The latest initiative, ICT for everyone a Digital Agenda for Sweden in 2011, reiterated that "Everyone of working age must have good digital skills to be employable or be able to start up and run businesses" (OECD, 2016[10]).

Teachers and schools are natural candidates to support the development of digital skills. Teachers are primarily responsible for all educational change and gaps in the digital skills of teachers could prevent the economy from reaping the benefits of digital transformation (Figure 7, Panel A). Furthermore, the teachers' preparedness was essential in the transition to remote teaching and learning during the school closures because of the COVID-19 pandemic. A high share of teachers in Chile uses ICT tools in the class for teaching (Figure 7, Panel B). However, teachers usually have difficulties in locating high-quality digital learning resources and software, lack clarity over learning goals, and insufficient pedagogical preparation on how to blend technology meaningfully into teaching (OECD, $2015_{[11]}$ ). In Chile, $51 \%$ of teachers reported that ICT skills for teaching were included in their professional development activities, which is lower than the average of the OECD countries in TALIS (60\%) (OECD, 2020[12]). At the same time, in Chile $17 \%$ of teachers reported a high level of need for professional development in ICT skills for teaching. During 2018, the Plan Nacional de Lenguages Digitales (Digital Languages National Plan) has been implemented to train teachers in the use of tools to promote the teaching of computational thinking and programming in the classroom. However, there is a need to incorporate the teaching of digital competences into the teacher's initial training, into the Good Teaching Framework and into the pedagogical and disciplinary assessments of the new teaching career. School directors should be supported and integrate digital development in the planning and management of their schools, including physical and technological infrastructure, digital resources and platforms, teacher training, coordination, planning and support for teaching practice.

Parents should also be aware and trained. Experience from Colombia shows how important is to give training to parents too. Escuela TIC Familia was an ICT project that aims to help parents and teachers develop skills to look after children. The Computers to Educate (Computadores para Educar) programme has been successful in providing Colombian schools with computers as well as training teachers and parents on the use of ICTs for educational purposes.

The strategy on how to integrate ICT in schools, teacher training, educational resources are complementary to digital infrastructure. A good example of a coherent programme supporting the transformation of society is Brazil and its Connected Education (Educacão Conectada) programme. The programme supports the universalisation of high-speed Internet access and promotes the pedagogical use of digital technologies in basic education, integrating them in the same programme: digital training for teachers, guides institutions to include innovation and technology as elements of education, brings together quality educational resources and invests in expanding access to high quality connectivity (OECD, $\left.2020_{[13]}\right)$. 
Figure 7. Training teachers to be drivers of digital transformation should be a priority

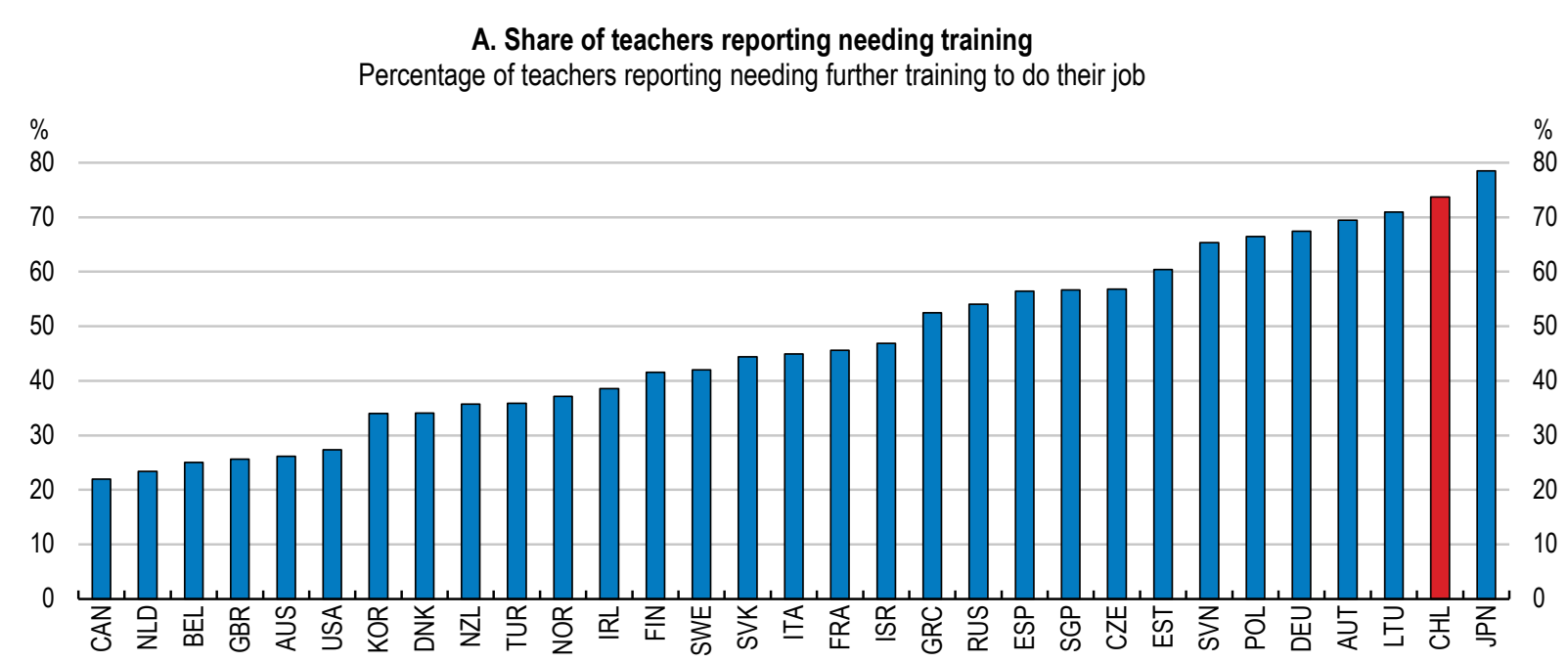

B. Percentage of teachers that let students use ICT for projects or class work

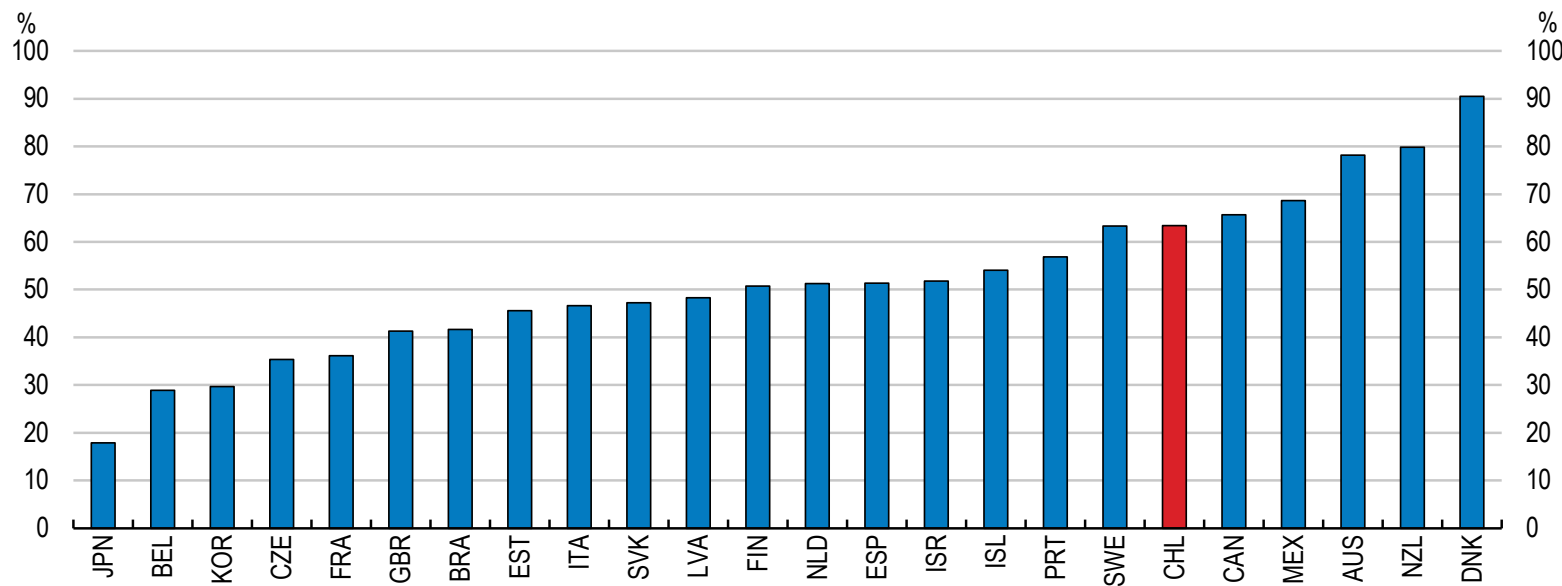

Note: In Panel A, data refer to the share of workers answering "Yes" to the question "Do you feel you need further training in order to cope well with your present duties?" Teachers are defined based on the population of adults aged 25-65 years old. Teachers are adults self-reporting working in the following two-digit occupations as classified by the International Standard Classification of Occupations (ISCO-08): Teaching Professionals (ISCO 23). Chile, Greece, Israel, Lithuania, New Zealand, Singapore, Slovenia and Turkey: Year of reference 2015. All other countries: Year of reference 2012. Data for Belgium refer only to Flanders and data for the United Kingdom refer to England and Northern Ireland jointly. Data in Panel B refer to 2018.

Source: OECD calculations based on Survey of Adult Skills (PIAAC); OECD, TALIS 2018 database.

StatLink ज्ञाs https://doi.org/10.1787/888934193858

The digital transformation of the economy brings along opportunities, but also entails some societal risks. Although access to Internet by 15-year-old students is at the OECD level, there is high exposure to risks and low utilization of opportunities in the use of technology as they make an extreme use of the Internet (Figure 8). Benefiting from digital opportunities depends not only on meeting the skills requirements, but also on managing digital security risks. Teachers should receive specialised training in software education and professional development programmes needed to prepare teachers and schools to educate students on digital security and privacy, understand the implications of some online behaviours and identify various forms of online harassment that build up in schools. Integrating digital security or digital citizenship responsibilities in the curriculum needs to be considered. 
Figure 8. Risks of digital transformation and extreme use of Internet should be avoided

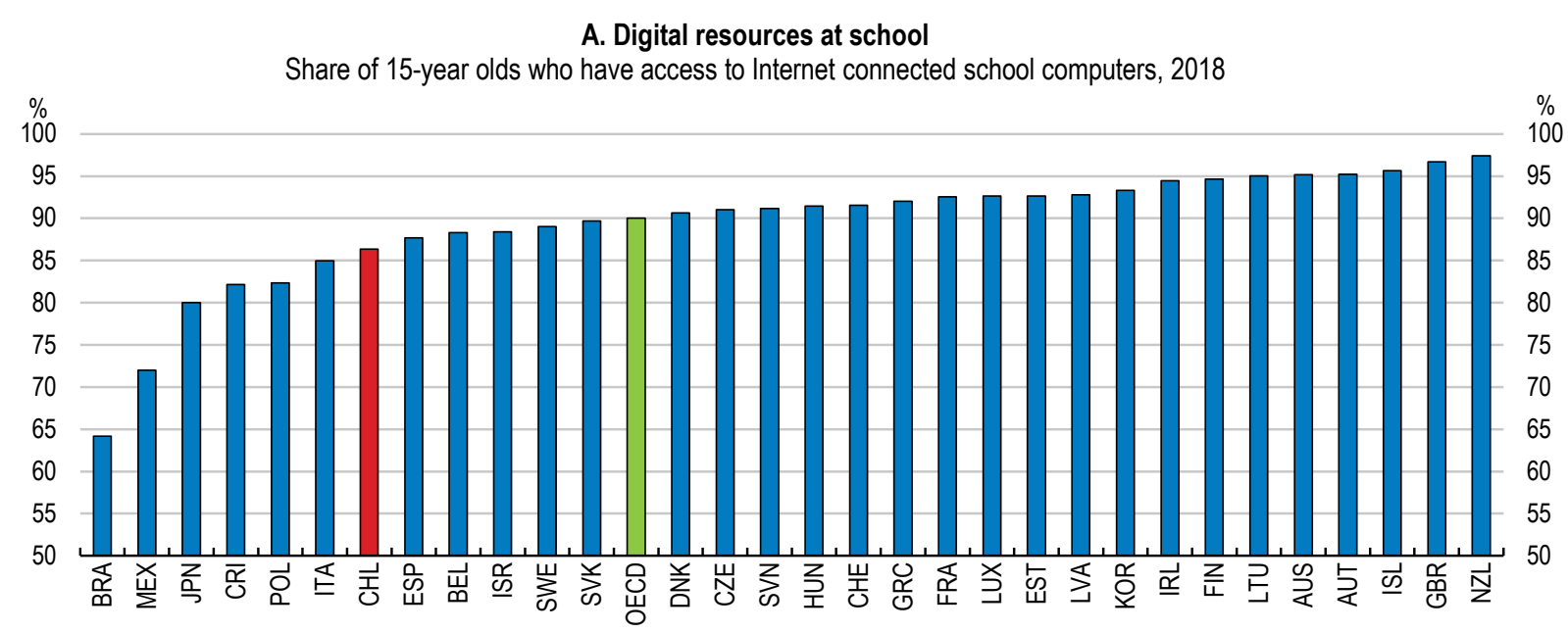

B. Extreme Internet use by children

Share of 15-year olds reporting to use the Internet for more than 6 hours a day on the weekend, 2018

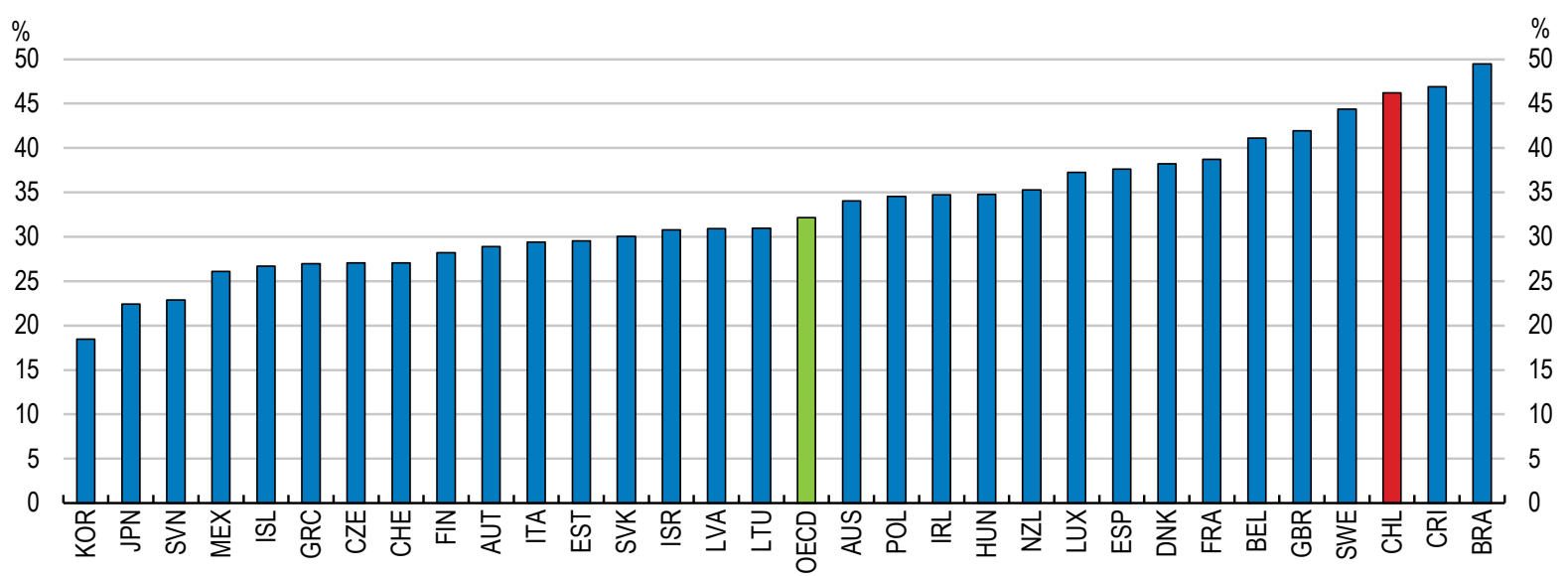

Note: In Panel A, data refer to students who have access to Internet connected school computers and who use them. In both panels, the OECD average is population weighted.

Source: Programme on International Student Assessment (PISA) 2018.

StatLink הत्ञाs https://doi.org/10.1787/888934193877

\section{Developing ICT specialists}

Seizing the benefits of technological change depends on the availability of ICT specialists: workers who can code, develop applications, manage networks and manage and analyse Big Data, among other skills. These skills enable innovation in a digital economy to flourish, but also support the infrastructure that firms, governments, commerce and users rely on.

Potential shortages of ICT professionals have been flagged in Chile, as in several OECD countries (e.g. OECD, (2017[14]]); OECD, (2019[15])). Although according to the OECD skills for jobs data base there is no a big shortage of ICT professionals at the moment, this could be driven by a not particularly high demand. However, ICT skills demand is likely to increase, particularly in the aftermath of COVID-19, and outstrip supply in the near future. This is problematic in a context where there is an increasing demand for jobs that require specialised ICT skills (Figure 9). Specialists in mathematics and computer science have experienced the fastest growth in demand in Chile between 2010 and 2015 (Amaral et al., 2019[16]). A growing number of Chileans pursue graduate degrees, but few do so in relevant areas for future 
competitiveness: $3 \%$ of graduates are in information and communication technology (ICT), and only $1 \%$ in natural sciences, mathematics and statistics (the lowest share of all OECD countries). Conicyt (currently ANID, the national agency for research and development), established in 2017, has a special call for pursuing graduate studies in Digital transformation through a programme Becas Chile. Approximately $20 \%$ of the budget was allocated for this "priority area".

\section{Figure 9. ICT skills are increasingly demanded in Chile}

Main skills demanded in the online labour market. Share of project/task occupations.

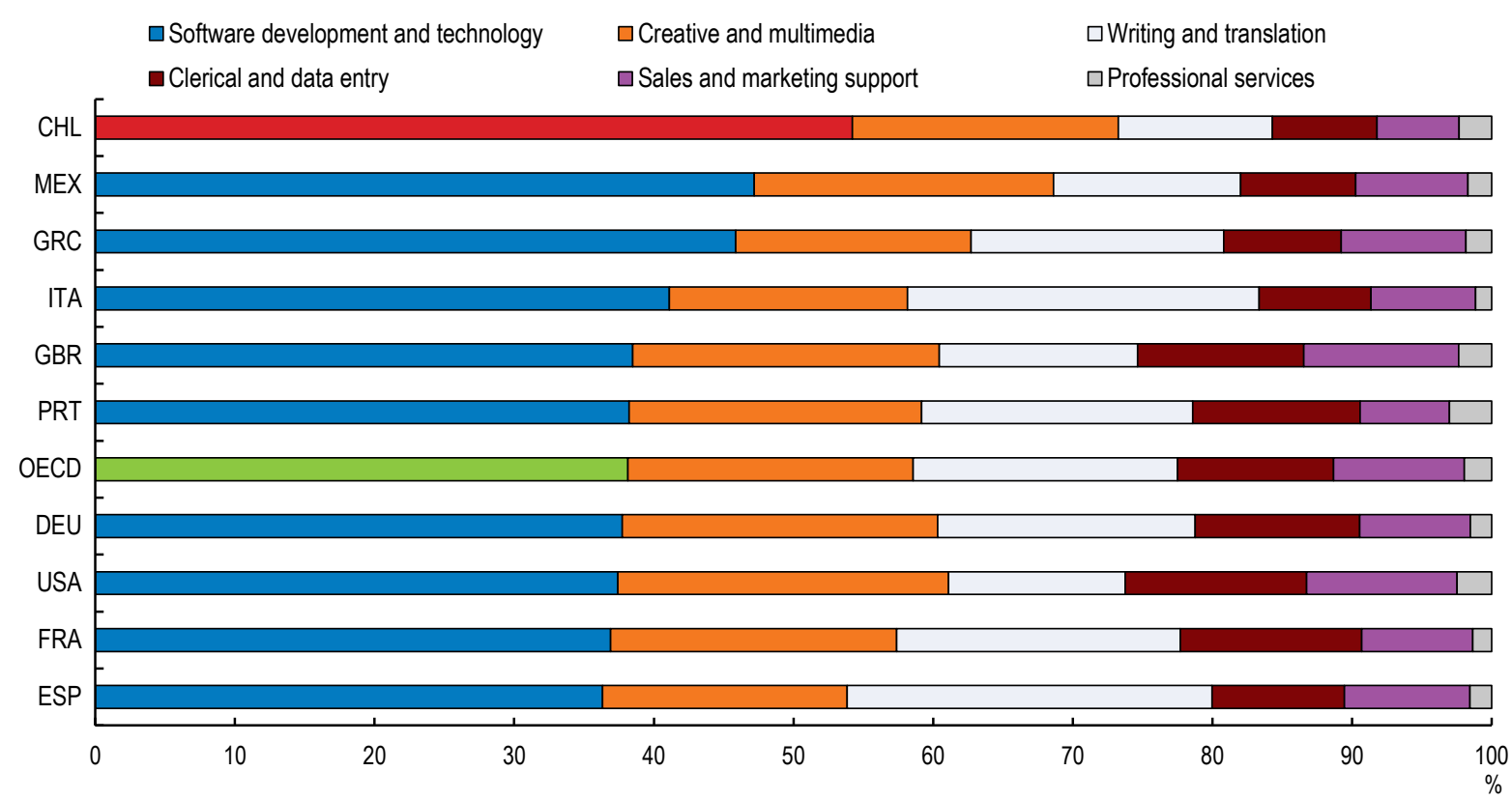

Note: Each bar displays employer countries' share of projects/tasks posted on online labour platforms between January and July 2018 by the occupation of project/task. The Online Labour Index is based on tracking all projects and tasks posted on the five largest English-language platforms, which account for at least $70 \%$ of all traffic to online labour platforms. OECD refers to an unweighted average.

Source: Online Labour Index in (Kässi and Lehdonvirta, 2018[17]).

StatLink त्ञाs https://doi.org/10.1787/888934193896

The shortage of high-skilled and tertiary educated workers in ICT-related professions leads to a particularly high wage premium (Figure 10). Computer and information technicians are some of the better paid technicians in the country with high employability levels on the first year of the programme, according to the web portal MiFuturo. In 2015, Chile experienced a 31\% gap in the number of available network professionals as percentage of the total demand of these skilled professionals, mainly in the areas of data centre, virtualization, software development and video (IDC, 2016 $\left.{ }_{[18]}\right)$. The quality and relevance of those professionals' skills are also an issue (IDC, 2016[18] ). Chile has a Visa Tech Program to attract international talent. Software companies such as Evernote and Everis have opened up locations in Chile, taking advantage of this programme and repatriating Chileans that have been working in tech companies in the Bay Area. 
Figure 10. Chile is experiencing a clear shortage of ICT workers

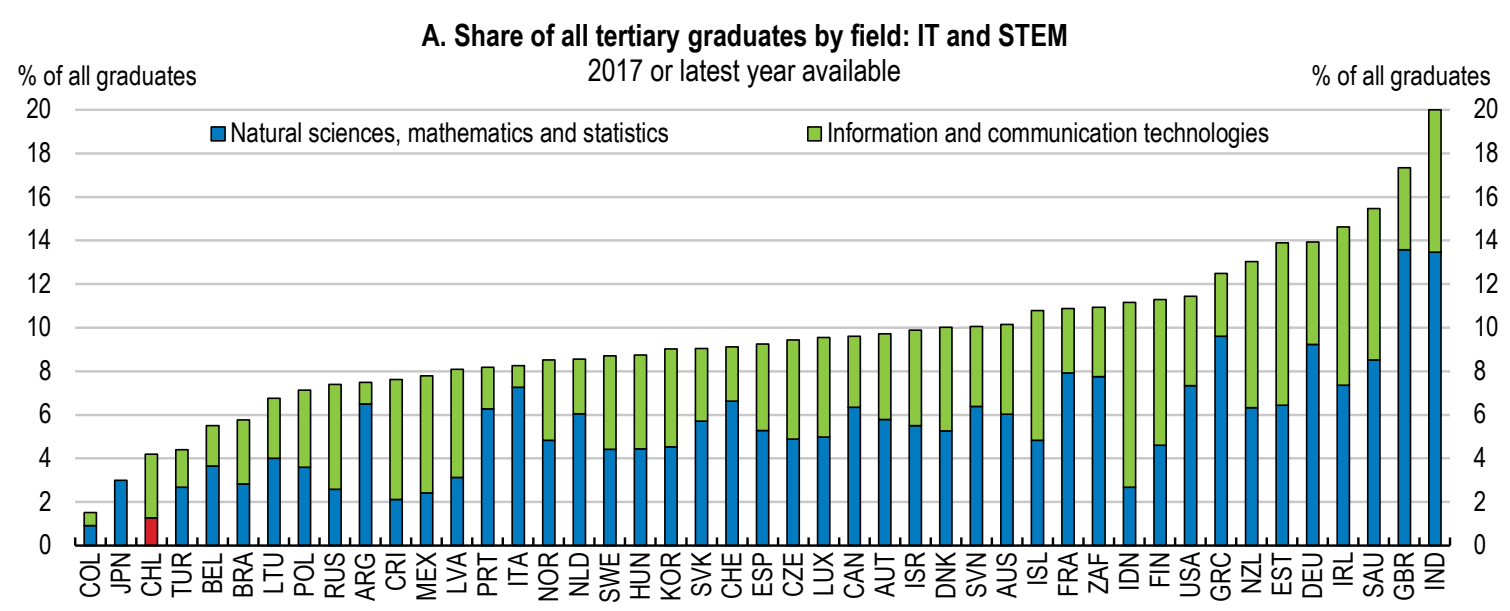

B. Relative earnings of workers with tertiary education

Upper-secondary

2017

C. Relative earnings of ICT and non-ICT workers

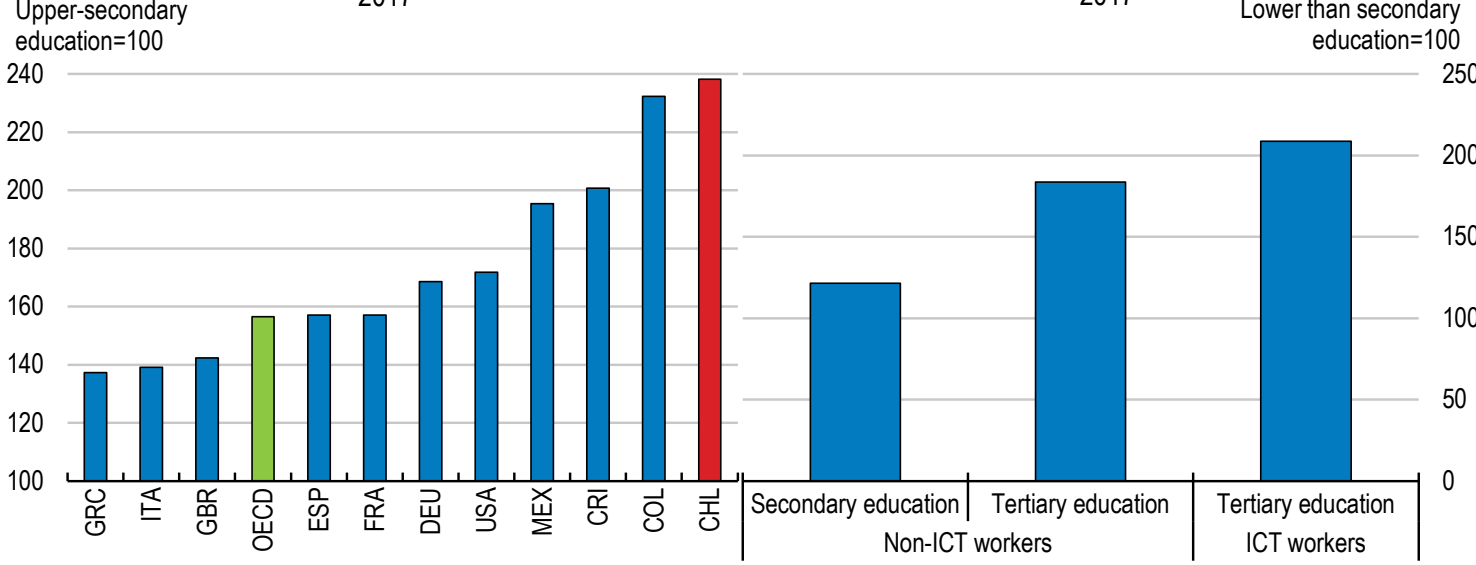

Note: Panel B refers to 25-64 years old with income from full-time and part-time employment. Panel C refers to 25-64 years old with income from full-time employment. In Panel $\mathrm{C}$, the bars show the estimated effect on labour earnings. Estimates are obtained through a mincer regression controlling for age, gender, education, if temporary contract, if informal job (defined as those not contributing to the pension system), self-employment and regional effects. ICT workers are ICT professionals (ISCO-08=25) and ICT service manage workers (ISCO-08=133).

Source: OECD, Education at a Glance database; Education at a Glance 2019: OECD Indicators - (C) OECD 2019; OECD calculations based on CASEN 2017.

StatLink त्गाड़ https://doi.org/10.1787/888934193915

Given the rapid pace of digital transformation, it is important to implement forward-looking programmes that strive to match current ICT training programmes with expected skills needs in various industrial sectors. This is the case of artificial intelligence, data science and cloud computing, for example. A good example in the country is the Data Observatory Foundation. Chile has a Natural Laboratory for space observation, attracting $70 \%$ of the world's observation capacity. There are approximately 700 students of astronomy in Chile, which is the country with the highest number of astronomers per capita. The exploitation of this Natural Laboratory confers Chile an opportunity to lead in the development of algorithms and technologies to process large amounts of data coming out of such observatories. The Data Observatory Foundation seeks to make available large datasets for science and industry to develop algorithms and train the next generation of data scientists in the country. Continuous updating of vocational programmes, as well as of university curricula, while providing career guidance, will be essential to close the gap between supply and demand in the labour market. Strengthening technology and communications specialties in technical and vocational secondary education would benefit mainly the most vulnerable students, who attend more technical and vocational secondary education (OECD, 2018 $\left.{ }_{[1]}\right)$. 
Higher education institutions and SENCE, the government training and employment institution, usually create new engineering or technical programmes. Involvement with and from the private sector to align and predict their needs is key for the relevance of the programmes. Chile does not have an institutional mechanism that allows the integration of the requirements of the productive sector to the training offer in a systematic and binding way (CNP, 2018[19]). The contents and curricula are defined by the Ministry of Education for secondary education, and by each educational centre for higher education. Technical and vocational training policy generally does not consider the productive sector. Although there have been advisory bodies in which the productive sector has participated (the most recent being the Advisory Council on Technical and Vocational Training), they are not representative of sectors and firms, and they only have an advisory role (CNP, 2018[19]).

Few examples have worked well when integrating the private sector. One example of collaboration with the private sector is "Talento Digital para Chile" focused on inactive, unemployed, vulnerable and female workers in coordination with all relevant public agencies and the private sector. A new national policy for Artificial Intelligence is under development and will consider the development of specialised education in training programmes. CORFO's New Engineering 2030 programme aim at the redesign of engineering education, enhancing applied research, and creating entrepreneurial ecosystems around engineering campuses. Some initiatives (such as "Destino Empleo" and the National Labour Observatory from the Labour Ministry) aim to gather and analyse labour market information to contribute and orient the decision making of different stakeholders, such as the system of Certification and Training, public and training institutions, and students. A web platform shows the information gathered by these initiatives. Destino Empleo shows the most demanded digital skills and occupations in the local labour market based on job postings. In coordination with SENCE (National Training and Employment Service), it also enables users to search for training courses related to those skills. Another good experience is the Advisory Council on Technical and Vocational Training, in which Ministries, public agencies, educational institutions and some business associations participate to detect skill needs and support the elaboration of educational programmes. The council is developing a national skill strategy. It will be important that results are aligned with programmes of technical educational.

Chile would benefit from consolidating and expanding the current initiatives, and a greater involvement of private sector in technical, graduate and post-graduate levels, modernising vocational training and updating curricula to endow the next generation of workers and managers with the skills needed. Vocational and professional education in Chile is usually pursued by vulnerable students, hence providing it with higher relevance and quality would boost growth and equity. Another challenge for skills development is the system of career accreditation and certification, which requires an update to bring it in line with the demands of the digital age, for example by shortening the training cycle and including digital skills into process (OECD/UN, 2018[20]). Also, integrating working experience for students will be key, as there is evidence of the high importance for the future employability. Putting in place incentives for firms to provide apprenticeship and internship programmes for students and teachers could help foster working experience.

As in most OECD countries, an overwhelming majority (81\%) of people employed as ICT specialists were men in 2017. Young men (16-24 year-olds) are more likely than young women to have programming skills in Chile, and elsewhere (OECD, 2019[21]). The share of female students in science, technology, engineering and mathematics is only $21 \%$ of all graduates in Chile, the lowest share in OECD countries (Mostafa, 2019[22]). This gender imbalance reflects in part educational choices. Only $5 \%$ of ICT students are female. However, usually women tend to use ICT more intensively at work (OECD, 2019 [21]). To ensure a more diverse pool of talent in specialised ICT positions, and to counteract gender divides in ICT skills, consorted efforts should be carried out to increase girls' interest in ICT from early stages. Providing highquality ICT education from a low age would be essential. Government initiatives, such as "Ingeniosas: ciencia y tecnología para todas", fostering the vocation for STEM among girls and adolescents, should be amplified and further supported. 


\section{Mobilise the private and public sector for digital innovation}

Digital innovation is a fundamental driver of the digital transformation. Digital technologies and data also drive innovation itself. But to start, to seize the opportunities of the digital transformation, it is necessary to have innovative firms. Closing the digital divide means also closing the innovation divide (Figure 11). Investment in ICTs is a necessary but not a sufficient condition for the diffusion of digital tools; a second condition is investment in complementary assets, knowledge-based capital (KBC) in particular, including innovation and research and development (R\&D). For example, incentives to invest in R\&D appear to be associated with greater adoption of most advanced digital technologies, such as customer relationship management (CRM) software and cloud computing (Andrews, Nicoletti and Timiliotis, 2018[23]).

To unleash digital innovation, policies should promote entrepreneurship by promoting start-ups and young firms; facilitate access to finance; support basic research, knowledge diffusion and open science; and open up government data $\left(\right.$ OECD, 2019 $\left.9_{[4]}\right)$. Policies should also encourage experimentation and new business models across sectors, including by promoting the flexible application or enforcement of regulation (e.g. regulatory "sandboxes").

\section{Figure 11. Bridging the innovation divide is necessary to increase productivity}

Percentage of firms that innovate

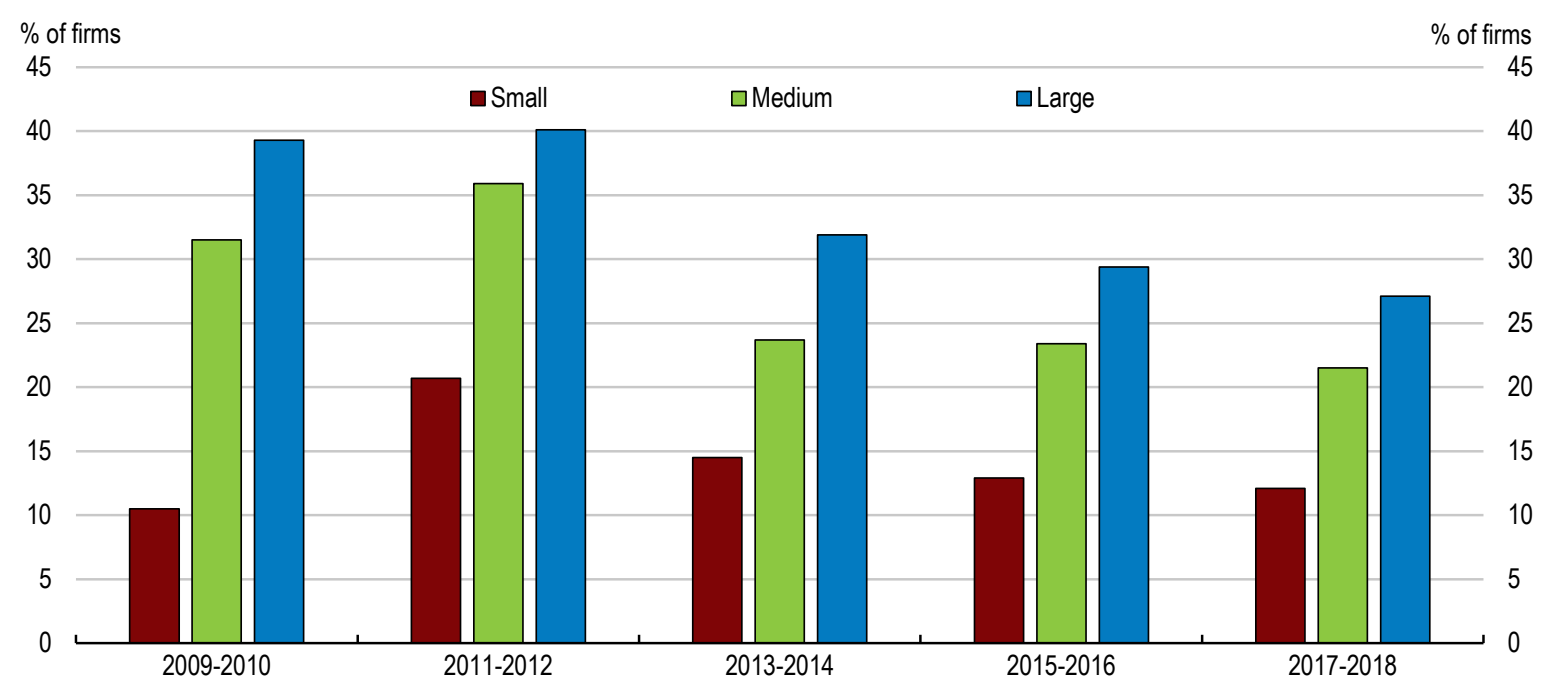

Note: Innovation in products, processes, organizational or marketing. Small size companies are defined as companies with annual sales between 2,400 Chilean unit of account (UF adjusted for inflation) and 25,000 UF. Medium size companies are defined as companies with annual sales between 25,000 UF and 100,000 UF. Large size companies are defined as companies with annual sales higher than 100,000 UF.

Source: Chile Innovation survey (Encuesta Nacional de Innovación), Ministry of Economy.

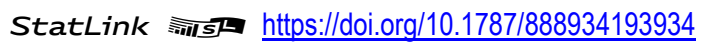

Chile spends relatively little on R\&D and innovation (Figure 12), with the R\&D intensity of information industries the lowest in OECD countries $(0.01 \%$ of GDP relative to $0.6 \%$ in OECD). Most of the resources spent in R\&D come from the public sector and the gap in business R\&D with OECD countries is especially pronounced (Panel B). According to national innovation surveys, only $11 \%$ of the companies have introduced technological innovations, as opposed to $35 \%$ in the rest of OECD countries. 
Figure 12. R\&D and innovation spending remains low
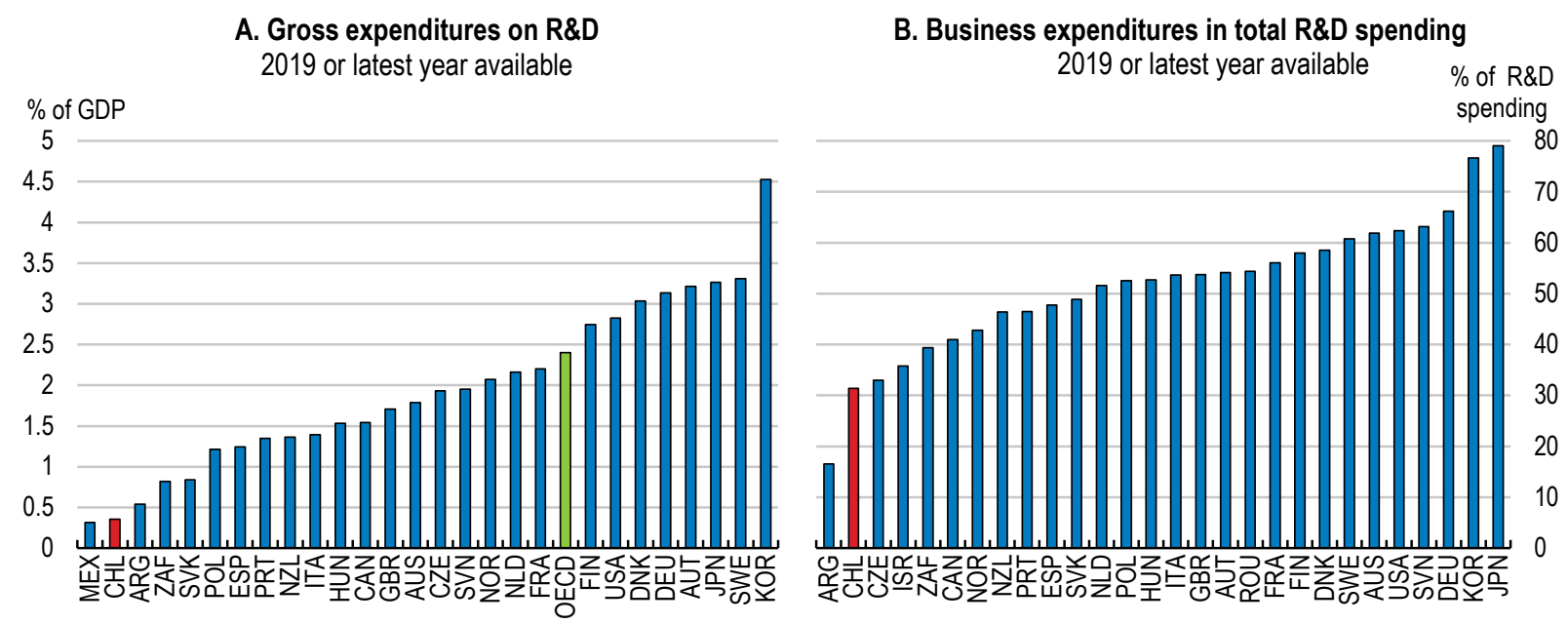

Source: OECD, Main Science and Technology Indicators database.

StatLink त्गाड़ https://doi.org/10.1787/888934193953

Chile has introduced a multitude of policies, implemented by various agencies, to promote R\&D and innovation. However, the scale and take up of innovation programmes has remained limited (Figure 13). One of the main instruments to foster innovation is a generous R\&D tax credit that can be carried forward indefinitely. The number of SMEs doing R\&D is on the rise, tripling over the last 6 years until 2017, as evidenced by the latest R\&D Survey (MEFT, 2019[24]). As of 2015, firms can simultaneously apply to subsidies and the R\&D tax incentive. Take-up of the programme has increased in the last decade (Panel B), benefiting mostly large firms (Intelis, 2017[25]). The government should make the incentive refundable, which would be beneficial for small and young innovative firms. Authorities should also consider an extension of the ceiling of the tax credit and measures to simplify certification process. Further incentives for SMEs to innovate should increase available financing, given that this is one of the main barriers for SMEs to innovate (Zahler, Goya and Caamanio, 2018[26]; MEFT, 2019[24]). Usually SMEs are not aware of the generosity of the R\&D tax credit system, so further efforts to raise awareness are warranted.

Available public support to firms' R\&D and innovation activity are complex, with many programmes having overlapping aims (OECD, 2018 $\left.{ }_{[1]}\right)$. Numerous programmes are run jointly by different agencies, reducing accountability. In a welcome move, the Ministry of Science, Technology and Innovation was created in 2019 for advising and collaborating with the Presidency in the design, formulation, coordination, implementation and evaluation of policies aimed at promoting and strengthening science, technology and innovation. It is also responsible for fostering inter-ministerial and interregional coordination and collaboration, and the development of joint initiatives within the public sector and public-private cooperation. The Ministry needs to foster articulation, coordination and connection of the different initiatives to streamline and boost the system's effectiveness. Greater coherence and integration between the different programmes at a national level should be achieved. A good example of this is the recently streamlined and simplified offer of CORFO, one of the main technological promotion agencies in Chile. 
Figure 13. Public support for innovation has increased but remains limited
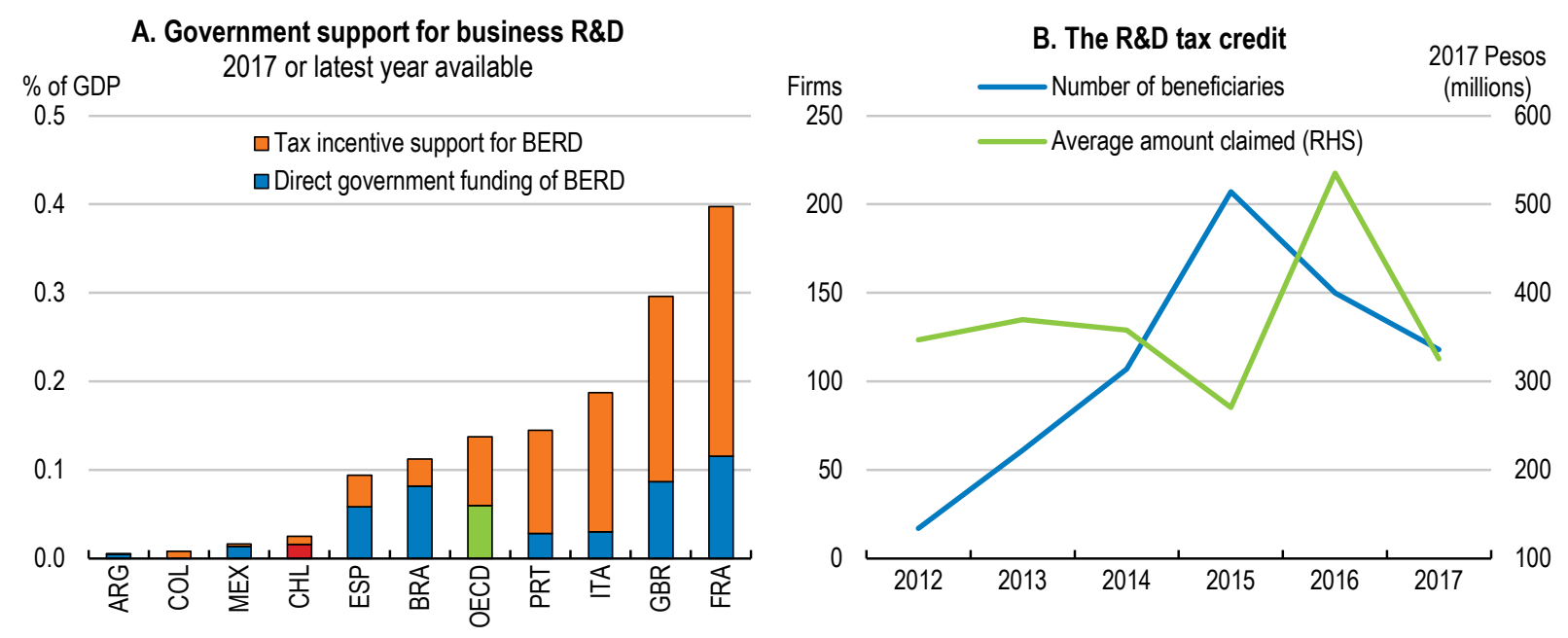

Source: OECD, R\&D tax expenditure and direct government funding of BERD database; CORFO (2018), Informe de Gestión 2014 - 2018 , Logros y resultados de INNOVA CORFO.

StatLink :्गाड़ https://doi.org/10.1787/888934193972

Strengthening business collaboration for innovation is key for start-ups and SMEs, but it stands currently low in Chile (Figure 14). In other OECD countries, traditional R\&D departments in large companies still exist, but there is a clear trend in the direction of appealing to open innovation - often by setting up startup incubators under the tutelage of a large corporation (OECD, 2019[15]). Fostering open innovation practices, such as crowdsourcing, platforms for collaboration, and open and living labs, would help to find innovative solutions to pressing challenges and nurture co-creation. Some examples on open innovation in Chile are the Fundación Chile's Expande Program in Mining or the CORFO's recent call to develop ventilators for the COVID-19 crisis. Strengthening intermediary organisations would allow to connect different actors in the innovation ecosystem (innovators, big firms, SMEs and investors) and facilitate their matching and collaboration for research and innovation. These innovation intermediaries are centres that connect firms, research centres, venture capital and service providers (e.g. intellectual property management) to find solutions to common problems. They could be particularly helpful for SMEs, since they can lower the costs related to innovation.

Collaboration is taking on greater importance in the digital era. In many countries, there are already special instruments to encourage industry collaboration, such as conditional grants (Guellec and Paunov, 2018[27]). Governments have also funded industry-level support programmes (e.g. the Dutch Top sectors), which include developing a strategic vision, investing in technology upstream, and encouraging co-operation between firms. Authorities might think of moving more of its support to developing linkages between firms while avoiding collusion between players, as collusion would hamper new entry. Knowledge intermediaries such as Fraunhofer in Germany or Catapult Centres in the United Kingdom also have an important role to play in facilitating interactive and collective innovation in the digital age. An example of policy initiatives to support collaborative innovation is the Dutch HTSM Roadmap Automotive 2018-2025, developed in collaboration among industry, research institutes and government. The roadmap identifies medium-term industry needs and sets research and innovation priorities in the fields of green and smart mobility. It highlights the importance of cross-sectoral co-operation and collaboration with international partners. Similar strategies have been adopted by many other European research agendas and priorities, such as those of the European Road Transport Research Advisory Council, the European Platform on Smart Systems Integration. 


\section{Figure 14. Business collaboration should be strengthened}

Percentage of businesses collaborating on innovation (product and/or process) with higher education or research institutions, 2012-2014

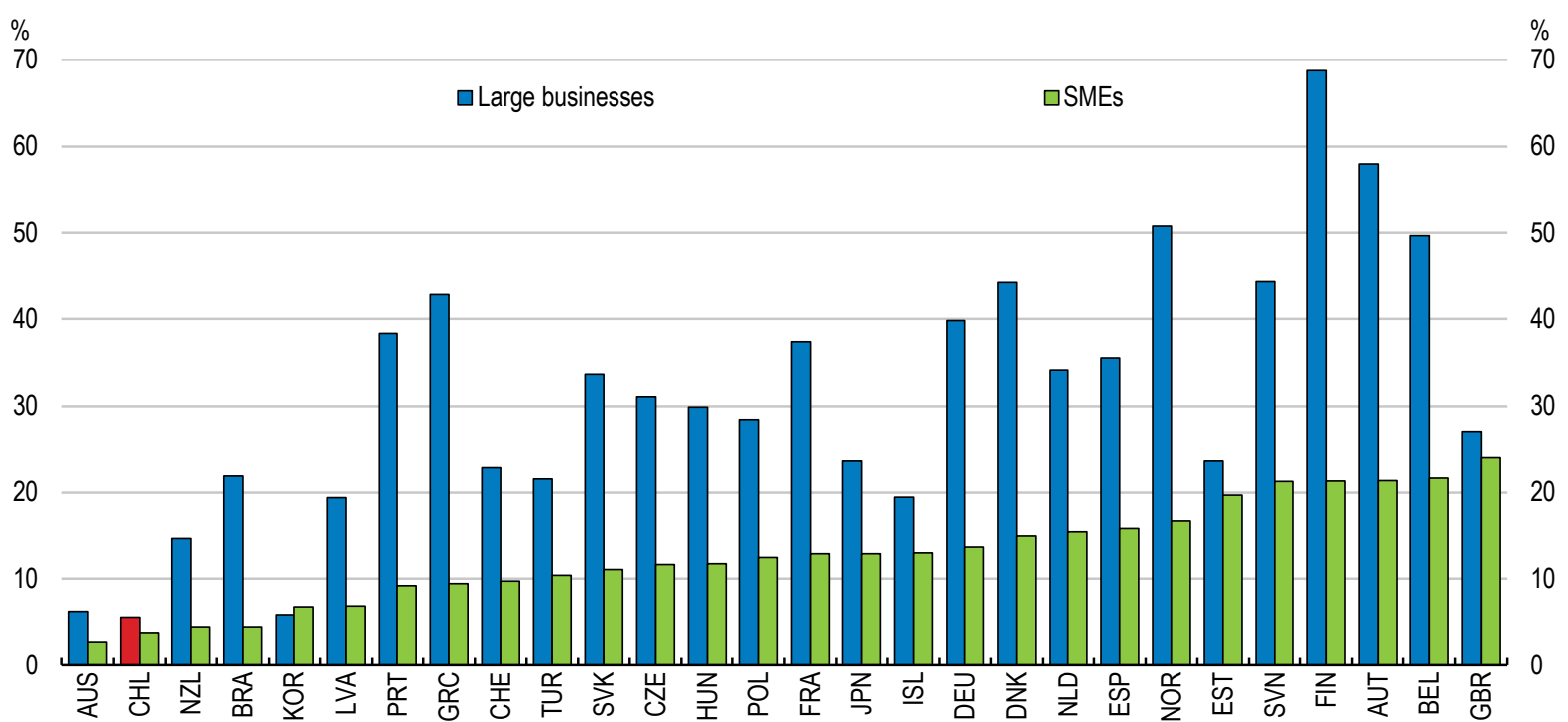

Note: Size is calculated on the basis of numbers of persons employed. SMEs are defined as businesses with 10 to 249 employees and large firms as businesses with 250 employees or more.

Source: OECD Science, Technology and Industry Scoreboard 2017.

StatLink : जाls https://doi.org/10.1787/888934193991

Service innovation is at the centre of the digital transformation. To fully benefit from the potential of digital technologies, service innovation needs to be reinforced. Available support for service innovation is more limited and financial constraints tend to be a more important barrier for innovation (Alvarez, Zahler and Bravo, 2013 $[28]$ ). As in most countries, many innovation policies have been conceived for manufacturing innovation, which is R\&D-intensive and results in patents, etc. (OECD, 2019[15]). Service-type innovation relies less on R\&D, and thus may not be eligible for policy support (such as the R\&D tax incentives). However, service innovation requires business to have a deep understanding of digital technologies that is not yet widespread, especially among SMEs of non-digital industries. Supporting service innovation may include supporting R\&D projects aimed at developing new services using new digital technologies (e.g. the Smart and Digital Services Initiative in Austria), or supporting manufacturing SMEs that will help them develop services related to their products (e.g. service design vouchers for manufacturing SMEs in the Netherlands) (OECD, 2019[15]). Addressing the specific needs for service innovation and design new programmes to address emerging needs will boost services innovation, which are pivotal for the digital era. One example is the programme Join to Innovate (Sumate a Innovar) that allows presenting service innovation proposals.

A characteristic feature of innovation today is that it is increasingly driven by the collection, processing and analysis of vast amounts of data. The public sector can drive "data-driven innovation" (OECD, 2019[4]). One of the most important things that the public sector can do to drive innovation is to enhance public sector data access. Open government data initiatives foster transparency and can increase civic trust, but also take on particular significance in a knowledge-based economy, where data and information are fundamental to innovation. The Chilean authorities have started to open data (see datos.gob.cl), however much potential exists to further open up public sector data, as is one of the OECD countries with lowest open useful reusable government data index (OECD, 2019 $9_{[4]}$ ). Another recent example is the open data on COVID-19 (see github.com/MinCiencia/Datos-COVID19/). 


\section{Boosting business dynamism and the diffusion of knowledge in the digital era}

The adoption of digital technologies is already supporting firm productivity growth in Chile (Box 3 ), although aggregate productivity has been on a downward path (Clapes, 2020). This is, at least partly, because digital technology diffusion has been slow and unequally effective across firms, failing to offset other headwinds on productivity. In Chile, there is a persistent division between a very small number of large and productive firms and a long tail of small and midsize companies with considerably lower productivity (see (OECD, 2021 $\left.{ }_{[29]}\right)$ ). As evidenced by other OECD countries, this productivity differential signals a low diffusion of knowledge and low business dynamism, holding back the reallocation of resources towards the most productive companies (Sorbe et al., 2019[30]). The adoption of digital technologies has been concentrated among the largest and most productive firms, which benefit from the human and organisational capital that is key to harnessing their full potential. Boosting digital adoption, mainly of productivity-enhancing tools and in micro and small firms, will be key to fully reap the benefits of digital transformation.

\section{Boost adoption and diffusion of digital tools in firms, especially small and medium-sized}

While Chilean firms are increasingly adopting digital tools, the gap with OECD countries remains considerable driven mainly by SMEs as large firms are almost on par with OECD standards (Figure 15). Although the penetration of Internet and mobile devices has increased significantly, few firms have adopted digital technologies associated with higher productivity, such as Enterprise Resource Planning systems (ERP), Customer Relationship Management software (CRM) and Cloud Computing. The gap between SMEs and larger firms are narrow with respect to simple connectivity, but large in the uptake of more sophisticated tools (Figure 15, Panel C). The use of productive applications is still highly concentrated in a few export companies and the service sector (INTAL, 2020[31]). The gaps are larger for micro firms, i.e. less than ten employees, bearing in mind that Chile has a large number of micro-firms that are not reported in OECD statistics. Lagging behind in terms of the diffusion of digital technologies implies bleaker prospects of reverting the decreasing trend of productivity and closing the existing productivity gap with more advanced countries.

Digital technologies are opening up new opportunities for young firms and SMEs to innovate and grow, including through e-commerce, digital business platforms, big data and Fintech. However, their current underuse by micro firms and SMEs highlights important barriers to adoption, which can include a lack of collateral to take risk and to access finance to invest in technologies, or a lack of key capabilities, e.g. human resources and management expertise. The lack of investment of in-house innovation and organisational capabilities limits the capacity of firms, especially in the case of SMEs, to take full advantage of innovation (Sepulveda, Alfaro and Vasquez, 2014 ${ }_{[32]}$ ), but also of data analytics, engage in e-commerce and participate in knowledge networks. Furthermore, structural factors, such as competition laws and the regulatory burden, may deter the business dynamism and a thriving SME population.

A lack of awareness of potential gains, a prerequisite to motivate firms to adopt digital technologies, may also explain the slow digital adoption notable in micro and SMEs. Some OECD countries, such as Estonia, have put in place programmes to increase entrepreneurs' awareness of the positive impact of digital transformation. Enterprise Estonia offers grants to industrial firms covering the costs of digital diagnostics performed by private consultancies to identify areas where digital transformation could be implemented in the company. The grants cover most of the costs of the diagnostics exercise and range between EUR 5 000-15 000. Publishing take-up rates and disseminating success stories would also help to boost digital adoption. 
Figure 15. The diffusion of digital tools needs a boost

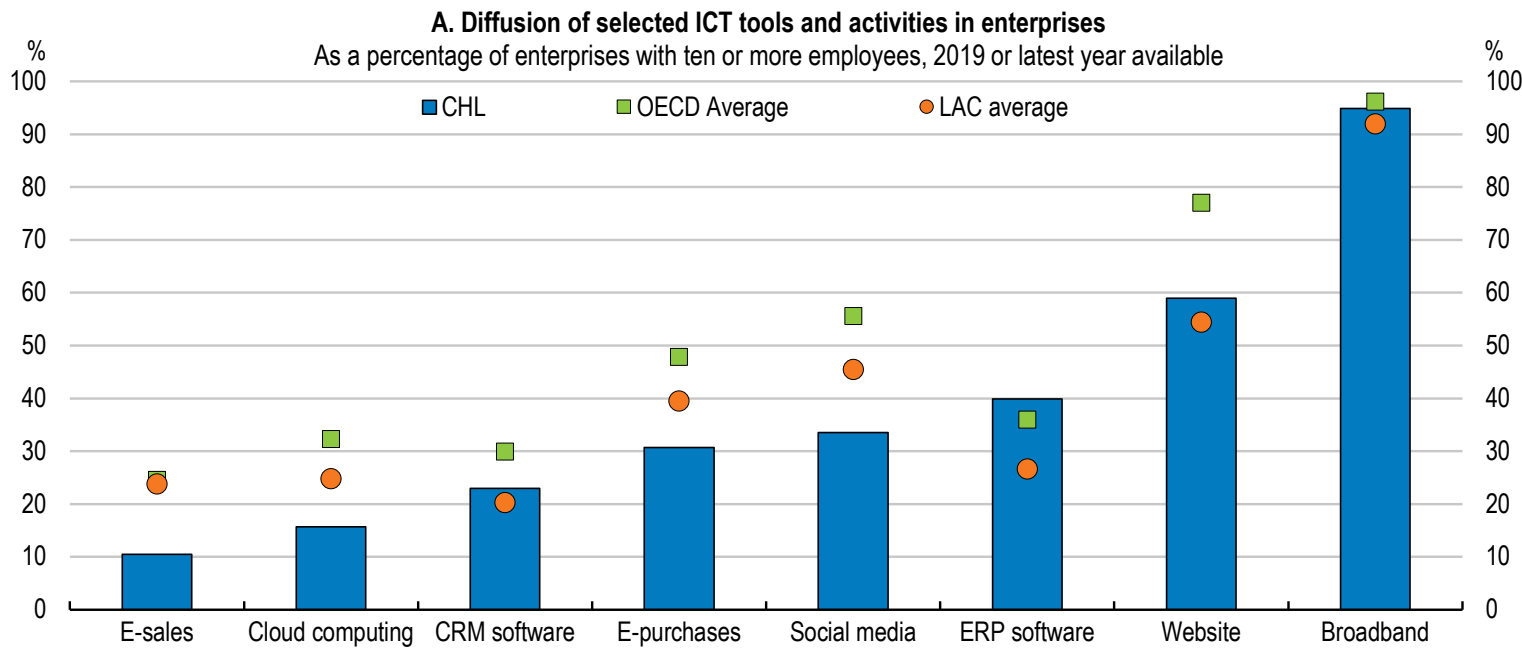

B. Diffusion of selected ICT tools: by firm size

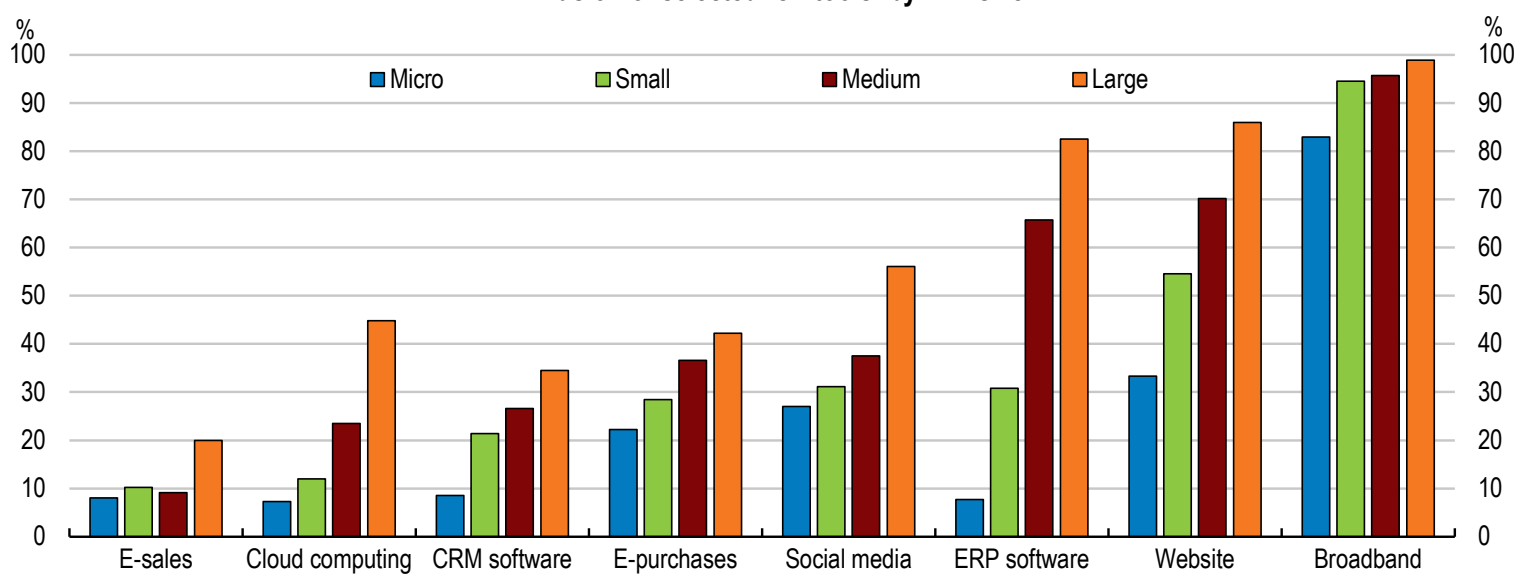

C. Diffusion of selected ICT tools: by year

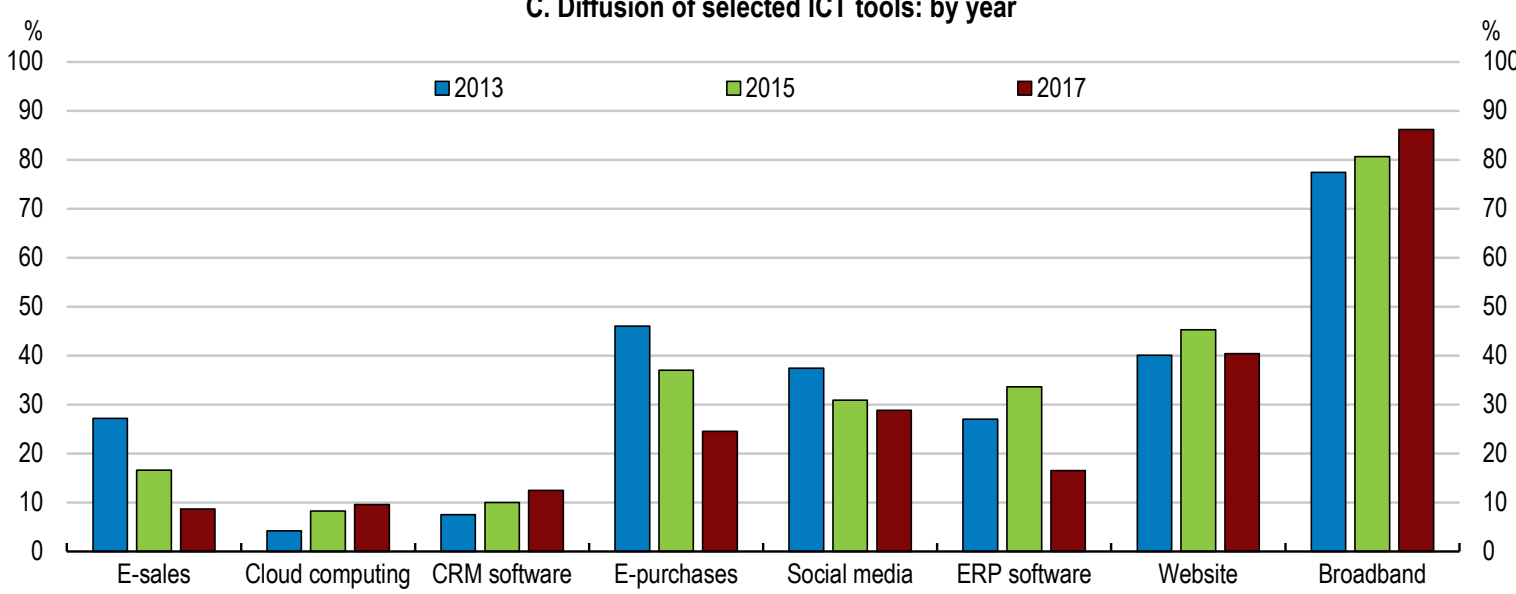

Note: In Panel A, OECD refers to an unweighted average of its members countries. LAC refers to an unweighted average of Brazil, Colombia and Mexico. Panel A only includes small, medium and large firms. Panel C includes micro, small, medium and large firms. Year 2017 for Chile in panels $A$ and $B$.

Source: OECD Digital Economy Outlook 2017; OECD calculations based on the Quinta Encuesta Longitudinal de Empresas (ELE5). 


\section{Box 3. Digitalisation is already having a positive impact on Chilean firms' productivity}

The impact of digital adoption on productivity has been analysed using microdata from a panel of Chilean enterprises (Hitschfeld, Garda and Ruiz, forthcoming $\left.{ }_{[33]}\right)$. Results indicate that with the exception of broadband, where the level of adoption is more than $90 \%$, all digital technologies are positively and significantly associated with productivity growth (Figure 16). Enterprise resource planning software (ERP) has the largest productivity impact, of 0.3 percentage points. Customer relationship management software (CRM), having a website and cloud computing also have a large impact. Results also suggest that the large and the most productive companies are more willing to adopt new technologies and derive greater benefits from them, which is related to the limited capabilities of, or lack of incentives for, SMEs to adopt best practices.

Across industries, particularly between manufacturing and services, the effect of digital technologies varies significantly, with a larger effect in manufacturing. Additionally, for companies that carry out R\&D activities, the effect of the adoption of digital technologies tends to be greater, especially when they are linked to more complex technologies, such as ERP.

\section{Figure 16. Digital adoption leads to higher firm level productivity}

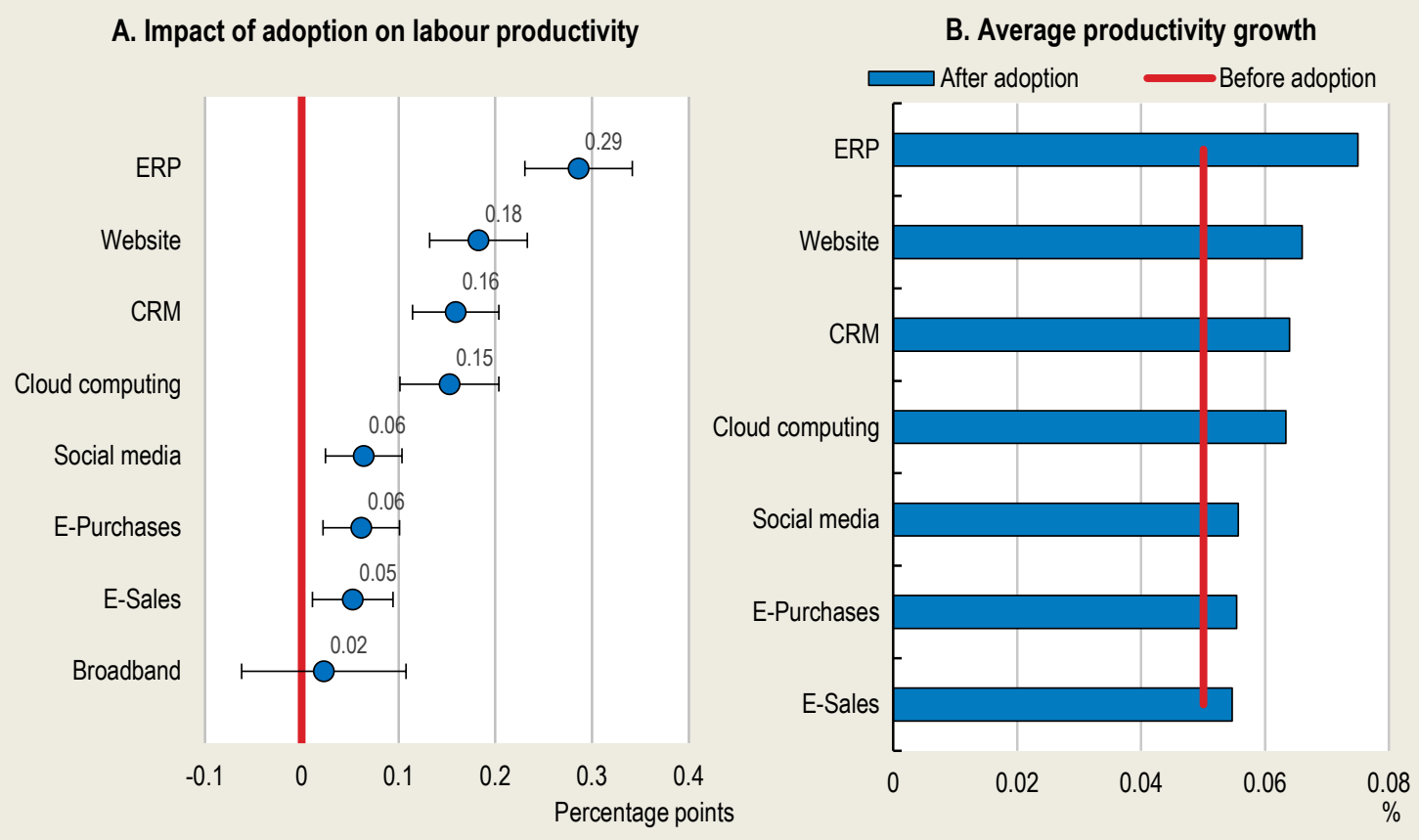

Note: Productivity is defined as labour productivity computed as total operational revenue over total workers and the adoption of each digital technology is measures through binary variables (dummies) at the firm level. Broadband is defined as any fixed broadband, ADSL or cable, dedicated Internet (fibre optic or private IP network), and mobile broadband via USB. A Pooled OLS model was used on a sample that includes all possible observations after a defined cleaning (unbalanced panel). Firm-level productivity growth is regressed on average productivity growth of the frontier, the firm's lagged gap to the productivity frontier, age and size, sector fixed effects and the dummy indicating the adoption of individual digital technologies. The frontier is defined as the 2 percent firms with highest productivity in each sector-year cell. Horizontal spikes correspond to $95 \%$ confidence interval. In Panel B, a company is "non-adopter" if it has not adopted that technology. The line shows the average labour productivity growth for the sample before adoption. Blue bars show the average labour productivity growth of the sample after all "non-adopters" adopt that technology. Standard errors are clustered at firm level.

Source: OECD calculations based on the last three waves of Encuesta Longitudinal de Empresas (ELE). 
E-commerce has been growing in Chile in the latest years (Figure 17), and the pandemic has further deepened this trend. During the CyberDay of early September 2020, 3 days that canalise more than $10 \%$ of online sales in Chile, more than 4 million transactions were generated, with sales estimated at USD 370 million, doubling the transactions of 2019. This has the potential to let firms grow and have access to larger markets and adapting to new customer needs and forms of consumption. Targeted training, mostly focused on the digital transformation of business services, e-commerce, or on the effective use of digital media, can boost digital adoption among SMEs. Recently, the Government has launched "Digitaliza tu Pyme" (Digitalise your SME), a program of the Ministry of Economy along with CORFO, that seeks to create awareness, deliver training and foster the adoption of tools such as e-commerce (Pymes en Línea), social media, delivery and logistics, digital tax matters (Despega Mipe) and business management. The aim is to digitalise 250 thousand SMEs by 2022. Other sub-programmes help SMEs to self-diagnose their level of digital maturity and guide them in terms of the actions to improve digitisation (Chequeo digital). After receiving training small firms will be able to access a Digital Toolkit that will allow them to finance the adoption of digital tools (Ruta Digital). After the appearance of COVID-19, authorities extended the programme seeking to arrive to 250 thousand SMEs. CORFO is also offering scholarships to learn on digital marketing, which can also help SMEs grow and increase productivity. Another programme, Innova Fosis, has the objective to increase sales of entrepreneurs from vulnerable backgrounds through the adoption of digital technologies.

Figure 17. E-commerce in Chile has been growing at a fast pace
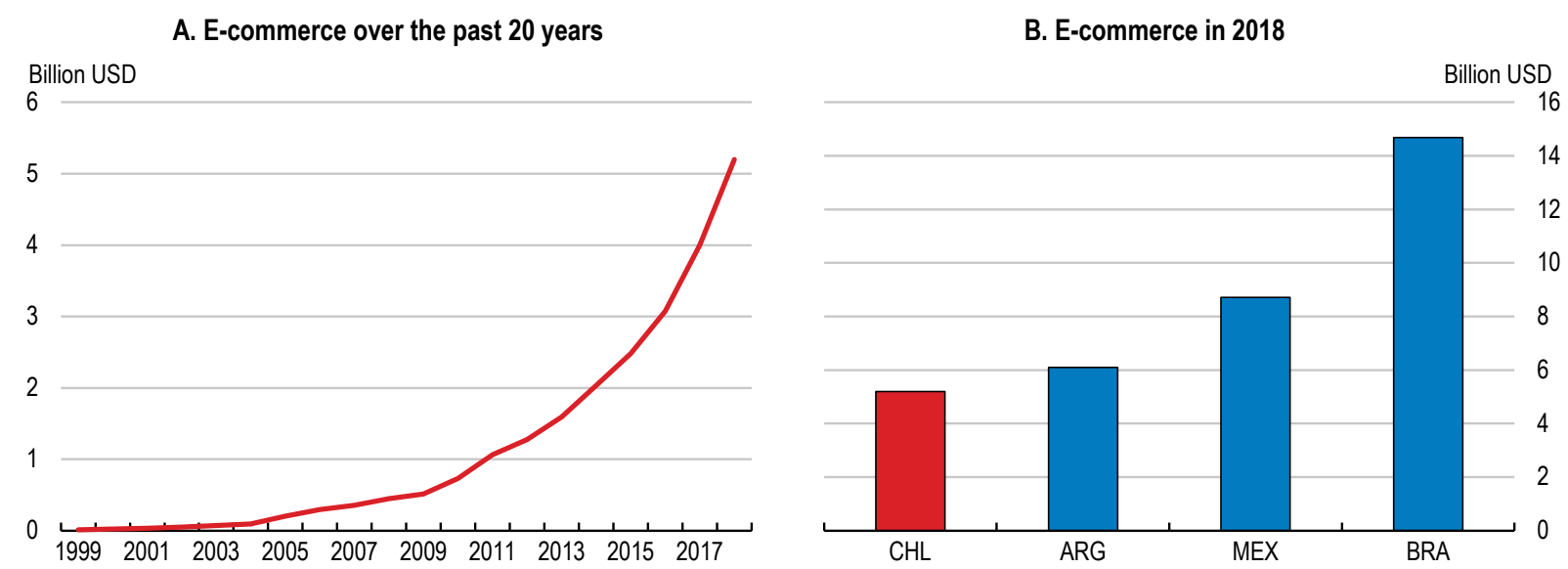

Note: Chamber of Commerce of Santiago de Chile, calculations based on Transbank and other surveys data. In Panel B, data for Mexico are from 2017

Source: Chamber of Commerce of Santiago de Chile; Statista.

StatLink ज्ञाs https://doi.org/10.1787/888934194048

To help SMEs overcome barriers to the effective use of more advanced digital tools, the government needs to amplify existing programmes and better target policies to SMEs. Online Platforms offer practical digitisation support for SMEs, especially during COVID-19 pandemic. For example, the United Kingdom offers free access to an online platform that gives both practical advice and inspiration, including instructions on how to set up a web page. Another platform provides advice on how to start and run a digital business, including building online brands and developing marketing campaign. A Massive Open Online Course (MOOC) offers cyber security advice for all firms. In of line of this, CORFO launched in 2020 a programme (Fortalece Pyme), seeking to support the installation and operation of centres to help SMEs improve their levels of productivity through the provision of services aimed at the adoption and use of digital technologies. 
Firms can be motivated to adopt digital technologies in response to stronger competition from their rivals (Sorbe et al., 2019 ${ }_{[30]}$ ). However, the particularly large dispersion of productivity between large and micro and small firms in Chile suggests inefficient allocation of resources, and a lack of competitive forces to push less productive firms out of the market (Albagli et al., 2019 [34]; OECD, 2018[1]]). Indeed, evidence from the National Commission of Productivity indicates that the lack of competition in local markets explains at least part of the slowdown in productivity since 2000 (CNP, 2019[35]). Although there has been some progress in the right direction, such as reforms to competition laws, a small number of large firms still dominates the economy (Figure 18, Panel A) and competition remains low in some key sectors, such as communications and banking.

Competition policy in the banking sector is being modernized. Authorities have passed a law to include financial portability, similar to the numerical portability in the communications sector, which would make it easier for people and firms to change financial institutions. It is expected that financial portability will increase competition in the financial services, reduce costs and time to carry out procedures for users firms and households as it allow firms and households to access financial services and products in better conditions.

Innovation in financial services and the development of FinTech has the potential to transform finance and capital markets, enhance competition, and increase the number of companies and people with access to financial products and services. It also makes it easier to facilitate transactions in other markets. Since the COVID-19 pandemic, Fintech has become even more important. During 2020 Chile announced that it is working on a Fintech bill with the aim of providing the same opportunities for those companies that provide financial services with a more intensive use of technology than traditional companies, and thus reduce the regulatory gap among them. The bill has the potential to promote competition in the financial markets and financial inclusion.

Fintech has lagged behind, driven at least in part by a lack of competition in the payments system. Indeed, the payment system has been dominated by Transbank, which charges high fees for every transaction banks and merchants do. Until recently, Chile operated a three-part model in which card issuers also hold the acquirer's license, concentrating on the same agents the roles of issuer and acquirer. In addition, the main card issuers, which are banks, have delegated the acquiring function to a single company, Transbank. Authorities are implementing a modification to the current payment system and establishing a four-part model considering the merchant, the user, the acquirers and the issuers. The aim is to give more competition and transparency to the transactions payment market, putting an end to Transbank's monopoly in the market. The proposal incorporates the card brands as a new player, with which the acquirer would lose the ability to set prices to issuers and merchants. New acquirers can also join, as has already started to happen. Increased competition could bring payment fees down by letting merchants choose the acquiring company with which they wish to operate, generating more competition. However, this will depend on how many acquirers join the market and the adequate regulation of the actors. Along with the Fintech bill, there is a bill to regulate the interchange rates ("swipe fees") for the payments system. The project establishes: the interchange rates for national transactions with payment cards will be subject to maximum rates, differentiated by card type (credit, debit, or prepaid); the Central Bank will determine the maximum interchange rates by card type; the levels and structure of the maximum interchange rates will be established through an economic study carried out by an independent technical entity with proven international experience.

Unnecessarily burdensome regulation (Figure 18, panel B) is a barrier for SMEs and start-ups to grow and emerge. The amount of time and/or money needed to comply with regulations is proportionately greater for SMEs than for larger firms, discouraging digital adoption. According to a recent study from the Productivity Commission, the regulatory system is characterized by low efficiency in the permitting process and a low degree of legal certainty (CNP, 2019 $[36])$. The low efficiency is manifested in long processing times, and is the result of a lack of coordination between agencies and the low use of technologies for traceability. There are also inconsistent rules and areas of contradiction and confusion around the 
jurisdictions of different agencies. The lesser legal certainty alludes to a lack of predictability with respect to the criteria for the admissibility and granting of permits, and clarity with respect to the ways in which it may be revoked.

\section{Figure 18. Competitive pressures remain low and the regulatory burden is high}
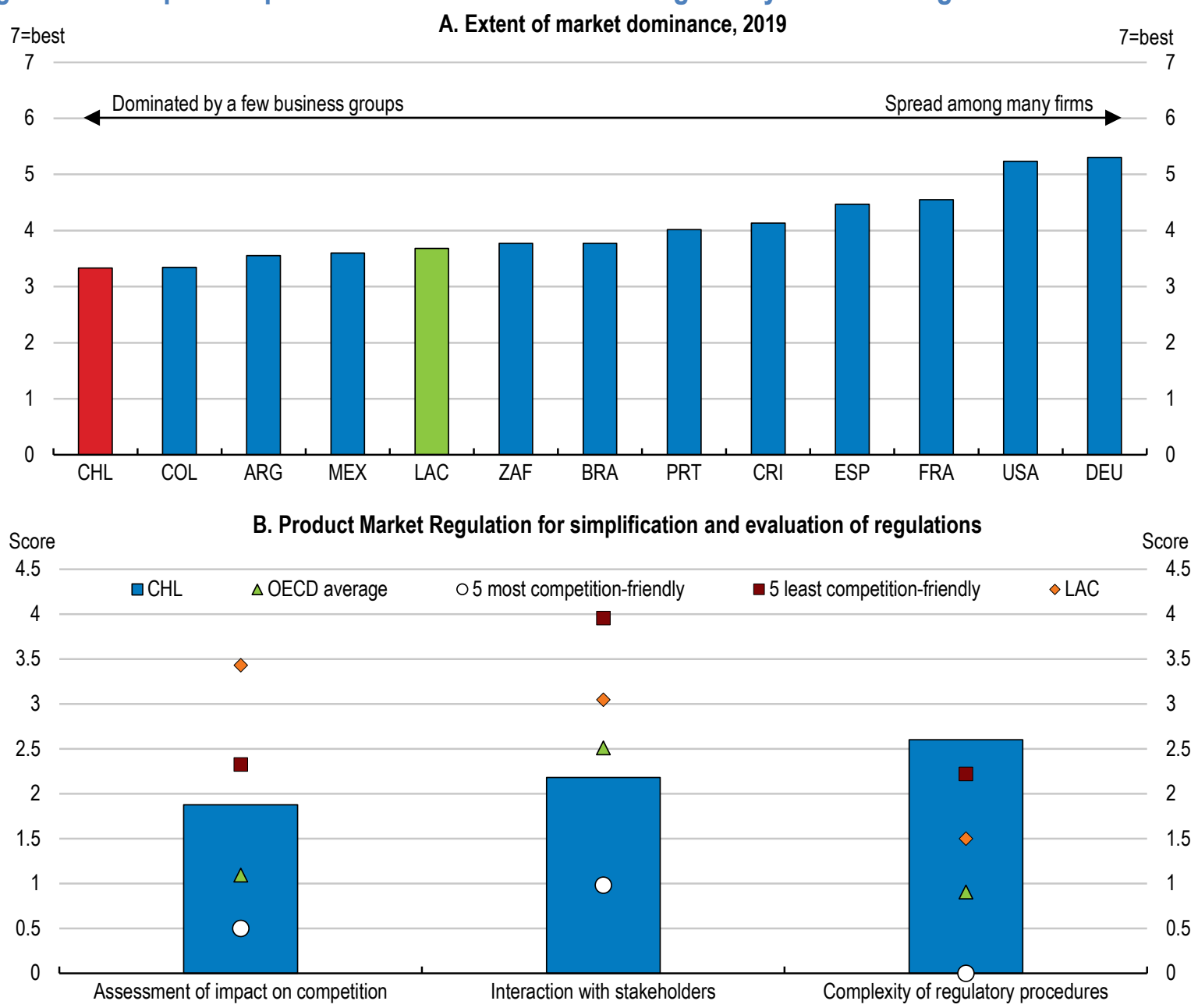

Note: The indicator in Panel A shows the extent of market dominance, 1-7 (best). In the World Economic Forum, Executive Opinion Survey, it is the answer to the following question: In your country, how do you characterize corporate activity? [ 1 = dominated by a few business groups; 7 = spread among many firms]. In Panel A, LAC refers to the unweighted average of Argentina, Brazil, Colombia, Costa Rica and Mexico. In Panel B, LAC refers to the unweighted average of Argentina, Brazil and Mexico.

Source: World Economic Forum, The Global Competitiveness Index 4.02019 dataset (version 04 October 2019); OECD, 2018 PMR database.

StatLink जils https://doi.org/10.1787/888934194067

Increasing the efficiency and transparency in the granting of permits and in their legal certainty would lower barriers to market entry, especially for smaller and young players, thus supporting competition. A reform of the permitting process would require the definition of the processing time for all existing permits, the digitalisation of all processes, including a mapping of all existing processes and incorporating internal positive silence rules. Authorities have also put in place a portal to denounce bureaucratic obstacles to SME entrepreneurship to lift them. An agency from the Central Government should be responsible for the surveillance of the whole process. Going in the right direction, the Government has set up a digital platform, SUPER, a Unified System of Permits, which acts as a single digital window for all sectorial permits that a project requires for its approval, allowing to follow the progress in all agencies. The portal is already working 
with 10 permits. Integrating more permits and procedures and public agencies is essential. Generalising positive silence rules could further ease firm entry and formalisation, by delaying the administrative burden on start-ups and focusing on ex-post controls. As part of the COVID-19 recovery plan, authorities are implementing measures to reduce burocracy, particularly for SMEs, such as providing provisional patents for SMEs to start operations and have one year to obtain the necessary permits for their final commercial patent.

Reforms of the notary profession and to reduce the use of notary procedures could ease significantly the administrative burden for firms, especially SMEs, and households. The competition authority has recently concluded a market study on Chilean notaries, highlighting that notaries are involved in more than 200 procedures, such as certifying bank guarantees or concluding real estate sales, but they are unequally spread across municipalities, lengthening procedures, and appear to frequently overcharge for their services (FNE, 2019 $\left.9_{[37]}\right)$. The study highlights the need to open the market of notaries and allow introducing technological innovations and data sharing with the administration in a systematic way to reduce the time of procedures and increase efficiency. There has been good progress on the use of the electronic signature and a bill being discussed in congress seeks to modernize it, but further expanding it on all notarial activities and notaries would ease the administrative burden. Another project aims at diminishing the number of tasks that require a notary, which would be welcome.

\section{Promote start-ups and young firms}

The progress on broadband infrastructure has allowed Chile to reap the benefits of the rising start-up scene in Latin America (OECD, 2016[38]). Chile is the fourth largest hub by number of start-ups in Latin America after Brazil, Mexico and Argentina, and the fifth largest by investors in venture capital (LAVCA, 2017[39]). Start-ups in Chile cluster in the traditional industrial hubs of the capital, with the metropolitan region of Santiago concentrating $80 \%$ of all start-ups (OECD, 2016[38]).

Digital transformation is driving the rise of start-ups and young firms of different forms, from online platforms to Fintech firms and in many different sectors, such as education, health, data-intensive services, etc.. Promoting the emergence of start-ups operating in the digital markets and nurturing the growth process of these start-ups and young firms into scale ups would lead to higher productivity and high-quality jobs.

Chile pioneered the start-up promotion in Latin America with the introduction of Start-Up Chile in 2010, a public business accelerator programme created for high-potential entrepreneurs to bootstrap their startups using Chile as a platform to go global. The programme's objective is to generate a socio-economic impact through the acceleration of innovative technological firms that allow the sophistication and diversification of Chile's economic matrix. Ten years after its creation Start-Up Chile has supported 1960 start-ups, has generated more than 7 thousands jobs in Chile and accumulated sales of USD 1.2 billion, and has managed to raise an important public and private capital. The programme is now being amplified. Authorities are increasing the number of start-ups supported by the programme from 180 to 400 and are creating a regional acceleration programme to ensure that, at least, 60 start-ups come from the regions outside the capital city.

Lack of financing seems to be one of the most important barriers for start-ups and firms to emerge and grow. Almost two out of three firms in Chile think that lack of funding is an important barrier for growth. This is even more problematic for micro firms and SMEs. According to the Commission for the Financial Market (CMF), credit activity, measured as the growth of credit placements, grew by $9.35 \%$ in $2017-2018$. However, the participation of SMEs in outstanding commercial loans decreased in 2018 to $19.9 \%$. Microenterprises and small businesses are responsible for the increase of outstanding SME loans, and Banco Estado has been the key financial institution working to improve access of SMEs to financing, together with the Corporation for the Promotion of Production (CORFO). 
CORFO and Start-Up Chile's programmes are the main instruments of SME capital financing, although other private and public initiatives have also developed. In 2017, CORFO launched the SME Credit Programme to improve SME access to alternative sources of finance and non-bank financial intermediaries. Digitalisation is creating a range of innovative financial services for SMEs and start-ups, from peer-to-peer lending to alternative risk assessment tools and Initial Coin Offerings (ICOs). Blended models are on the rise, and the Fintech (including crowdfunding) is becoming more central in the SME finance landscape (Koreen, Laboul and Smaini, 2018[40]).

Digital transformation increasingly creates both new opportunities and new challenges for SME financing. This includes new approaches to credit risk assessment and new digital tools for SME financing. Fintech, defined as technology-enabled innovation in financial services, is becoming more and more important in easing SMEs' access to finance. It is also ensuring financial inclusion for some segments of the SME population that are traditionally unserved or underserved by financial institutions and markets. SMEs use FinTechs to help them with their financial needs, including securing working capital, hedging foreign exchange risk and managing cash flow. Evidence shows that efficiencies generated by open banking in the SME sector can be significant, and that the products and services powered by open APIs bring real value to SMEs (FinteChile and EY, 2019 $9_{[41]}$ ). Fintech has also contributed to decrease transaction costs for lenders wishing to reach out to underserved segments of the SME population, such as firms in rural and remote areas, micro-enterprises and informal ventures (OECD, 2020 [42]).

Policy makers around the world are encouraging open banking, whereby financial institutions are obliged to share their data with third-party financial service providers, in the expectation that this will spur competition in the financial industry. The aim is that small business owners and entrepreneurs can share banking data securely and easily within a well-functioning open banking protocol. Such regulation could also encourage financial innovation by making banking data available to financial sector start-ups, as well as established actors (OECD, 2020[42]). For instance, the Australian government agreed to the recommendations made in a review on open banking in May 2018. Over the 2019-22 period, open banking will be implemented in several phases in the country. Similarly, the PSD2 (Revised Payment Service Directive) is being implemented in the European Union since 2018 (with certain provisions becoming mandatory only later, so as to allow the financial sector time to adapt). PSD2 obliges banks operating in the area to provide third-party financial providers access to their customers' accounts through open APIs.

Some countries have made their legislative framework more favourable to innovation in the financial sphere (OECD, 2020[42]). In addition to new regulations concerning investment-based crowdfunding Fintechs implemented in 2017, Brazil decided to regulate credit Fintechs in 2018. Two specific business models have been authorised: the peer-to-peer lending model is regulated as a Sociedade de Crédito entre Pessoas (SEP), and the balance-sheet lending is regulated as a Sociedade de Crédito Direto (SCD).

Fintech's ecosystem in Chile has registered a 2-fold increase in the number of start-ups between 2016 and 2019 to more than 100 start-ups (Figure 19) (Finnovista, 2019[43]). The Fintech industry has grown by $34 \%$ in 2017 and 29\% in 2018 (OECD, 2020[42]). This rapid growth highlights a thriving ecosystem offering a wide range of financial services for SMEs, ranging from payments and remittances to loans and crowdfunding and scoring services. This was taken into account by the Ministry of Finance, which announced in April 2019 the sending to Congress of a Bill that will regulate and strengthen this industry. Chile has the opportunity to lead the development of the Latin American Fintech sector, boosting growth and innovation. 
Figure 19. Chile has room to increase the number of Fintech start-ups

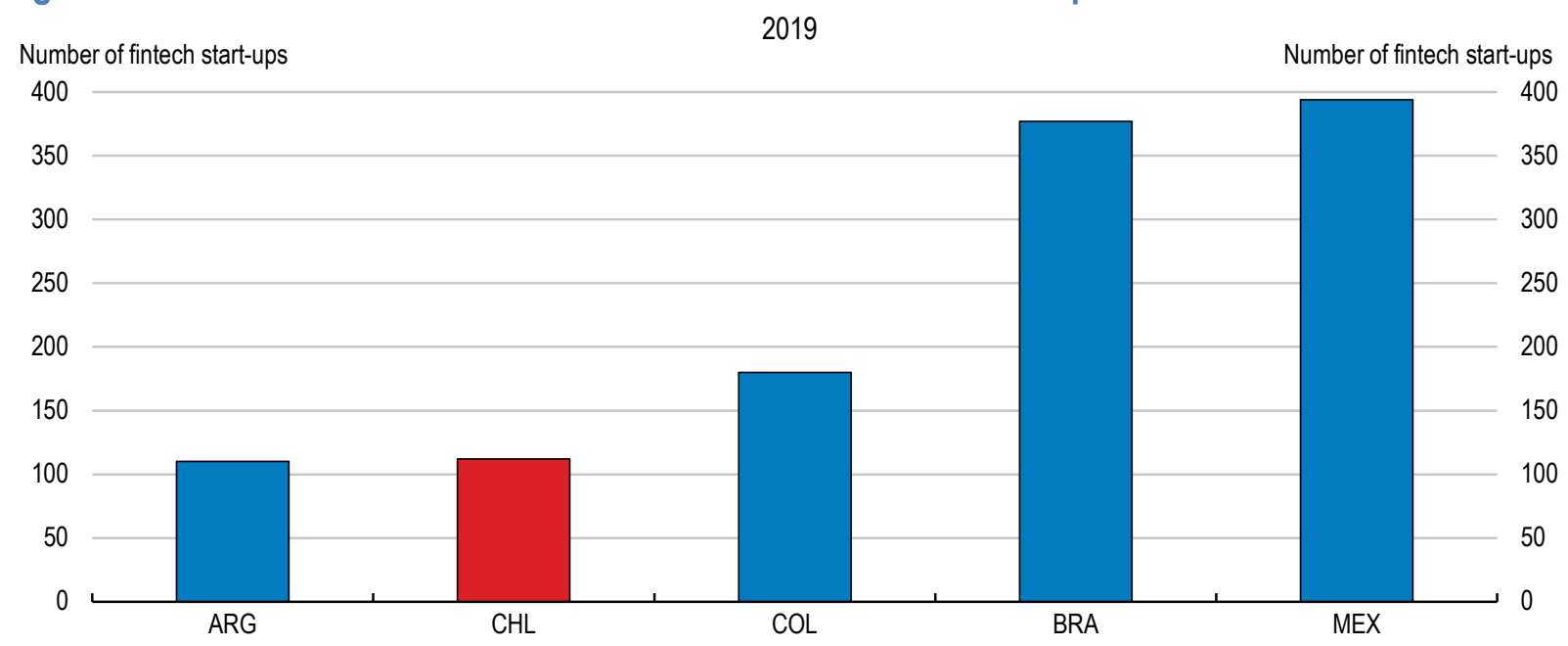

Note: Data refer to 2018 for Argentina and Brazil.

Source: Finnovista.

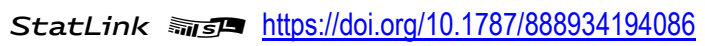

The availability of venture capital and angel investors is one of the essential determinants for FinTech, and more general for all start-ups development (FinteChile and EY, 2019[41]). Research has shown that crosscountry differences in the availability of risk capital are significant and positively related to the speed of technological diffusion (Saia, Andrews and Albrizio, 2015[44]). Venture capital has increased, and Chile has one of the most developed industries in Latin America, but the development has stalled (Figure 20). There is also an issue of low amounts of investment in venture capital (FinteChile and EY, 2019[41]). Angel investors have played an important role financing start-ups, but remain weak (FinteChile and EY, 2019[41]).

\section{Figure 20. The development of venture capital has stalled in Chile}

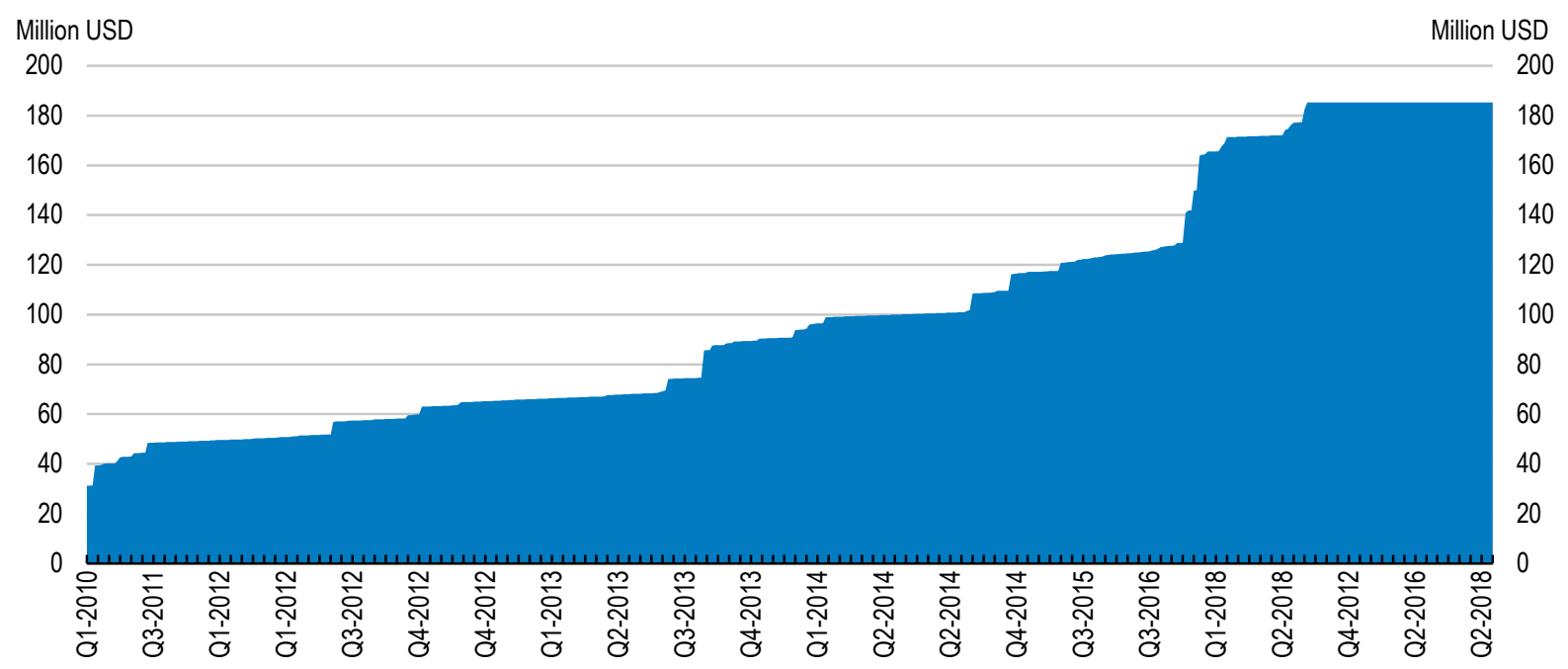

Source: Production Transformation Policy Review of Chile - ㄷ OECD 2019. 
Overall, there is a need for more diversified financing options for start-ups, including alternative forms of debt and hybrid tools (OECD/G20, 2015 $\left.5_{[45]}\right)$. Increasingly, tax incentives are being used in a number of countries as a way to address asymmetries in the treatment of profit and losses which can help in removing barriers and encouraging more investment in start-ups, particularly important for venture and angel investors $\left(O E C D, 2019_{[46]}\right)$. Other way OECD countries have been facilitating the growth of venture funding is, directly, through funds or co-investment funds (in which public money is used to encourage and leverage private investment). Also, fund-of-fund vehicles have been used (a "fund of funds" is an investment strategy consisting of holding a portfolio of other investment funds rather than investing directly in shares, bonds or other securities). The Yozma Fund in Israel is an often referenced example of effective government policy for developing the local venture capital community (OECD, 2019 [46]). Finally, developing a healthy entrepreneurial ecosystem is critical for the development of angel investors and venture capital markets.

Fintech can support productivity and growth by strengthening financial development, inclusion, and efficiency, but may pose risks to consumers and investors and, more broadly, to financial stability. There is a need to incorporate Fintech activities into the financial regulatory perimeter, such as crowdfunding and the activities associated with cryptocurrencies. In a welcome move, the Ministry of Finance has announced it would work with the Financial Stability Council to develop regulation for the industry.

A regulation that generates greater confidence in the Fintech sector and promotes investment, balancing the opportunities and risks of Fintech and coupled with incentives for companies to invest in the sector through Corporate Venture Capital models, would help developing further the sector. Examples in the region can be found in Colombia or Brazil. The Colombian Superintendence of Finance has launched a broad strategy for the promotion of sustainable and responsible innovation in the financial sector. As part of this strategy, channels have been established to exchange with the financial sector on innovation (elHub) as well as a sandbox environment (laArenera) allowing firms to test new technologies and business models under observation (OECD, 2019[47]). Several companies have initiated its activities under the scheme since February 2019. In Brazil, the Central Bank, the Commission for Security Markets and the Private Insurance Regulators are currently elaborating proposals for regulatory sandboxes, allowing firms to experiment with innovative business models and products, while at the same time enhancing regulatory capabilities (OECD, 2020[13]).

Sandboxing offers a regulatory perimeter for innovative business ideas to be tested in a controlled environment (OECD, 2020[42]). The rationale behind such an approach is to allow for more flexibility and experimentation for innovative (and typically small-scale) financial activities. Certain conditions are imposed on the businesses in order to ensure consumer protection, and consumer feedback (concerning both the business idea and its regulation) is an essential component of this kind of framework. Apart from the establishment of a regulatory sandbox, flexible regulation may take the form of reduced licencing requirements, like in the Netherlands and the United Kingdom. In return, businesses benefitting from these schemes can be obliged to remain below a certain number of customers or sales figures, like in Australia. Under certain conditions, a business idea that has failed may also be exempt from certain legal requirements. Often, conditions regarding consumer protection are relatively strict, including the designation of a dedicated point of contact or advisor within the business, with whom regulators can remain in dialogue throughout the process.

\section{Prepare for changes in international trade}

Digital transformation can help Chile to diversify its export basket and gain markets, transforming the country from a commodity-based to a high value-added goods and services economy. Digital transformation is creating new trade opportunities for firms to sell more products to more markets. It is increasing trade in goods and services across all sectors and allows countries to draw greater benefits from their trade agreements (López González and Ferencz, 2018[48]). These new opportunities are particularly beneficial for SMEs as they reduce trade costs, allowing for more efficient co-ordination of 
global value chains, enabling the diffusion of technologies across borders and connecting businesses and consumers globally (López González and Ferencz, 2018[48]; López González and Jouanjean, 2017[49]; WTO, 2018[50]).

Services play a crucial role in enabling digital trade transactions. The benefits of digital transformation can be derailed by restrictive policies on digitally enabled services that impose cumbersome and costly trading conditions on firms. There is room to improve the regulatory environment affecting digitally enabled services (Figure 21). As in other countries, the regulatory environment affecting infrastructure and connectivity, among which are measures affecting the movement of data, are increasingly relevant (Ferencz and Gonzales, 2019 [51] $)$. Barriers related the electronic transactions are also the main contributors to the restrictiveness. This is due to lack of pro-competitive regulations on interconnection measures, online tax registration and declaration is not available to non-resident foreigners, and international standards for cross-border transaction deviate from internationally standardised rules. Also, Chile has regulations that fail to provide equal treatment to foreigners and nationals with regard to the protection of trademarks, copyright and related rights. In June 2020, in a welcome step, Chile introduced a VAT simplified registration and compliance regime for non-resident suppliers of B2C digital services.

\section{Figure 21. Digital Services Trade Restrictiveness is high}

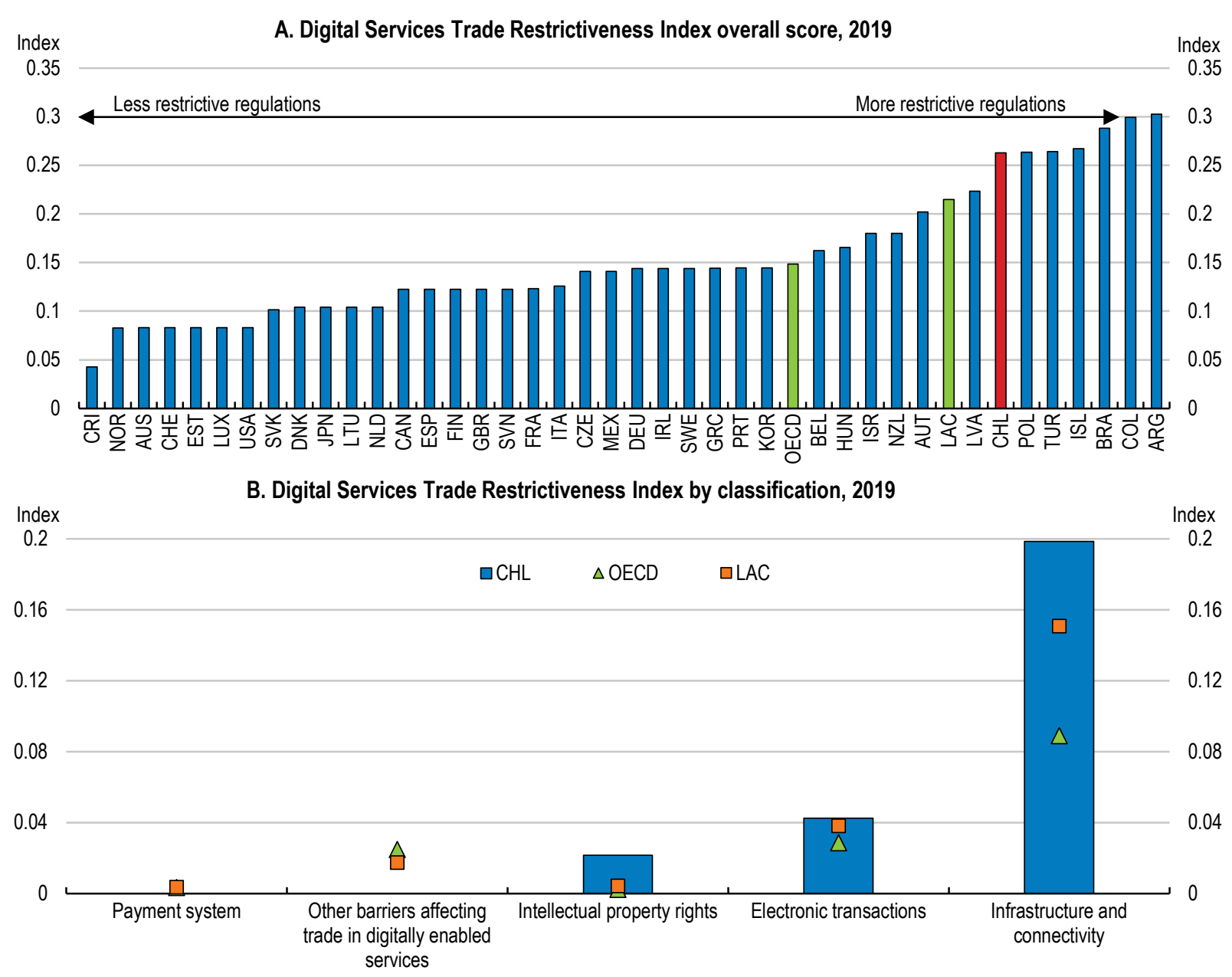

Note: STRI indices take the value from 0 to 1 . Complete openness to trade and investment gives a score of zero, while being completely closed to foreign services providers yields a score of one. LAC refers to the unweighted average of Argentina, Brazil, Colombia, Costa Rica and Mexico. $O E C D$ refers to an unweighted average of its member countries.

Source: OECD, Digital Services Trade Restrictiveness Index database. 
The interoperability of national regulatory frameworks is becoming an increasingly important determinant for international trade (Casalini, López González and Moïsé, 2019 $9_{[52]}$ ). (Figure 22) shows that Chile's regulatory environment in 2018 was most similar to regulation in many European countries and the Unites States. However, differences in regulations are relatively large with regard to the region, including Argentina, Brazil, and Mexico. The government, therefore, should pursue multilateral solutions and enhanced international co-operation to reduce regulatory frictions with the region.

Working with the region to modernize and harmonize e-commerce and digital regulations and ensure interoperability of the Internet across the region would be especially helpful for SMEs and start-ups. Common regional regulatory and policy frameworks in areas, such as free circulation of digital goods and services, privacy, consumer protection laws, cybersecurity, taxation of products and companies would help lower the costs for companies to operate across the regional market, incentivize start-up formation, and fuel the expansion of digital services (Suominen, 2017[53]).

\section{Figure 22. The interoperability of national regulatory frameworks with the region could improve}

Regulatory heterogeneity of Chile compared to each country in the figure, 2019

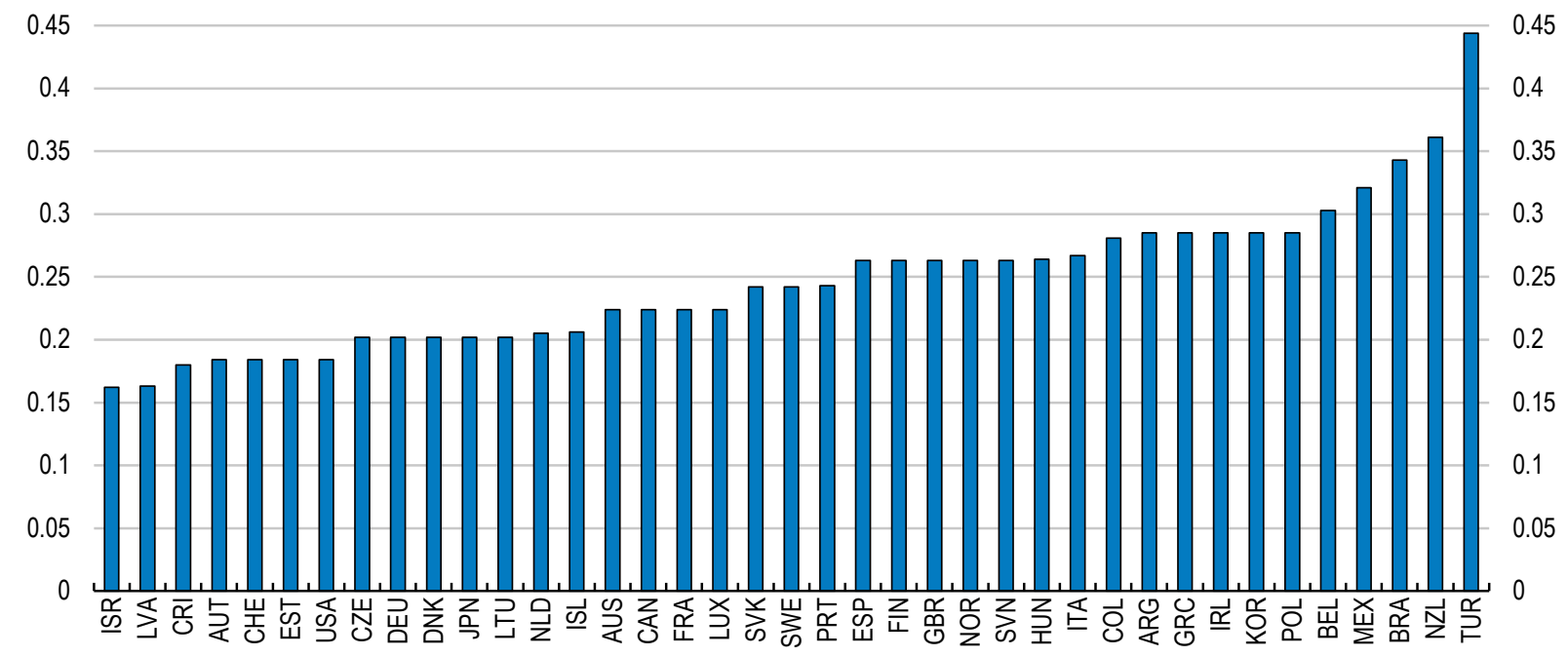

Note: The figure shows the OECD DSTRI heterogeneity index. The index assesses - comparing Chile with respect to each country showed in the figure- whether or not the countries have the same regulation as Chile. For each country pair (Chile-other country), the index reflects the (weighted) share of measures for which the two countries have different regulation. Hence, the index reflects heterogeneity with regard to Chilean regulation.

Source: OECD, Digital STRI Heterogeneity Indices database.

StatLink 제

\section{Monitor competition to avoid the concentration pitfall}

The digital economy poses new challenges for competition policy. Concerns about "winner take all" dynamics unleashed by digital technologies and the market power that some digital firms have developed are legitimate. Network effects (increased utility of a product/service with an increased number of users) and "scale without mass" (a possibility of adding new users at virtually no cost), which characterise some digitalised markets, tend to create "winner-take-all" or "winner-take-most" outcomes (OECD, 2019[54]).

Digital transformation may also support or facilitate new forms of anticompetitive conduct, limiting competition and generating substantial harm. For example, the increasing use of pricing algorithms can potentially enhance competition but also, on occasion, increase the risks of collusion (OECD, 2017[55]). A bill currently in discussion aims at establishing stronger penalties for cartels on markets for necessity 
products, a welcome move given that these products represent a large share of the spending for the most vulnerable households. Other measures under development would give the competition agency higher oversight capabilities, such as the ability to monitor bank transactions and access information from the telecommunications. Small businesses may also be discouraged to innovate and to grow if large or international players have dominant market positions, which may well be the case in an economy where technology leaders increasingly capture most market shares. The developments in Al, with data generated by those who have created and own the technologies and platforms that gather the data, may, to the extent it cannot easily be reproduced, enhance barriers to market entry, leading to increased market concentration, raising competition concerns.

Recent trends in the global economy support concerns of the competitive intensity of more digitalised sectors. There is evidence of declining business dynamism and growing industry concentration (Bajgar et al., 2019[56]). Mark-ups, which measure the difference between the market price that a firm charges for its output and the firm's average per-unit production cost, have been increasing on average across firms and countries, especially in the most digitally-intensive sectors (Calligaris, Criscuolo and Marcolin, $2018[57]$ ). Additionally, the number of merger and acquisitions doubled globally during 2003-2015 (Bajgar, Criscuolo and Timmis, 2019 $\left.9_{[58]}\right)$.

When it comes to concrete changes to the competition policy framework to address the challenges digital transformation possesses, there is no clear consensus yet. There are also views that establishing a new digital regulator, which could have responsibilities ranging from facilitating portability, interoperability and micro-payments, to participating in merger reviews would help. There are also calls for ensuring anticompetitive digital sector mergers are notified and assessed through new merger notification requirements.

There are also some non-controversial measures to promote competition in digital markets. Namely, better and faster co-operation among competition authorities, continuing to use existing enforcement tools in digital markets when warranted, and further reliance on market studies to understand competition problems in digital markets outside the framework of enforcement action.

The Chilean competition authority, Fiscalía Nacional Económica, has an active competition advocacy role to play to prevent collusion and monopolisation in digital markets. The Fiscalía could continue systematically reviewing the competitive pressures focusing on digital sectors by conducting market studies and applying the guidelines of the OECD's Competition Assessment Toolkit, which has been revised in 2019, in light of the global digital transformation developments. It will be required monitoring carefully network and economics of scale effects, including mergers and acquisitions in digitally-intensive sectors and concerns about pricing algorithms that could function in the same way as explicit collusion.

Competition policy will increasingly need to assess how conduct and mergers affect innovation as well as new dimensions of quality, such as consumer privacy (OECD, 2018[59]) or the concentration of personal and non-personal data as a result of a merger. Stronger tools, such as joint investigations, are needed to enhance international cooperation between competition authorities, and their cooperation with other regulators, such as consumer protection and data protection authorities.

\section{Preserving social cohesion and helping workers make the most out of a dynamic labour market}

\section{Digital transformation creates new jobs, but is also challenging $50 \%$ of the existing ones}

Digital transformation may bring many new opportunities for workers, improvements in job-quality and foster inclusive growth. Digital transformation can boost job creation in digital-intensive sectors, which is still low in Chile (Figure 23). It can bring efficiency gains as sharing-economy platforms expand, and 
improve labour market inclusion for individuals typically excluded from the labour force, such as women and youth, helping to close existing marked gaps. Digital transformation can also make possible working at a distance, as evident during the lockdowns put in place to reduce the propagation of COVID-19. In a welcomed move, in March 2020 the congress in Chile passed the teleworking law given teleworkers the same status as any other contract worker, regulating security, hours of work and other workers' rights.

\section{Figure 23. Employment in digital-intensive sectors remains low in Chile}

Employment in digital intensive industries, percentage of total employment, 2016 or latest year available

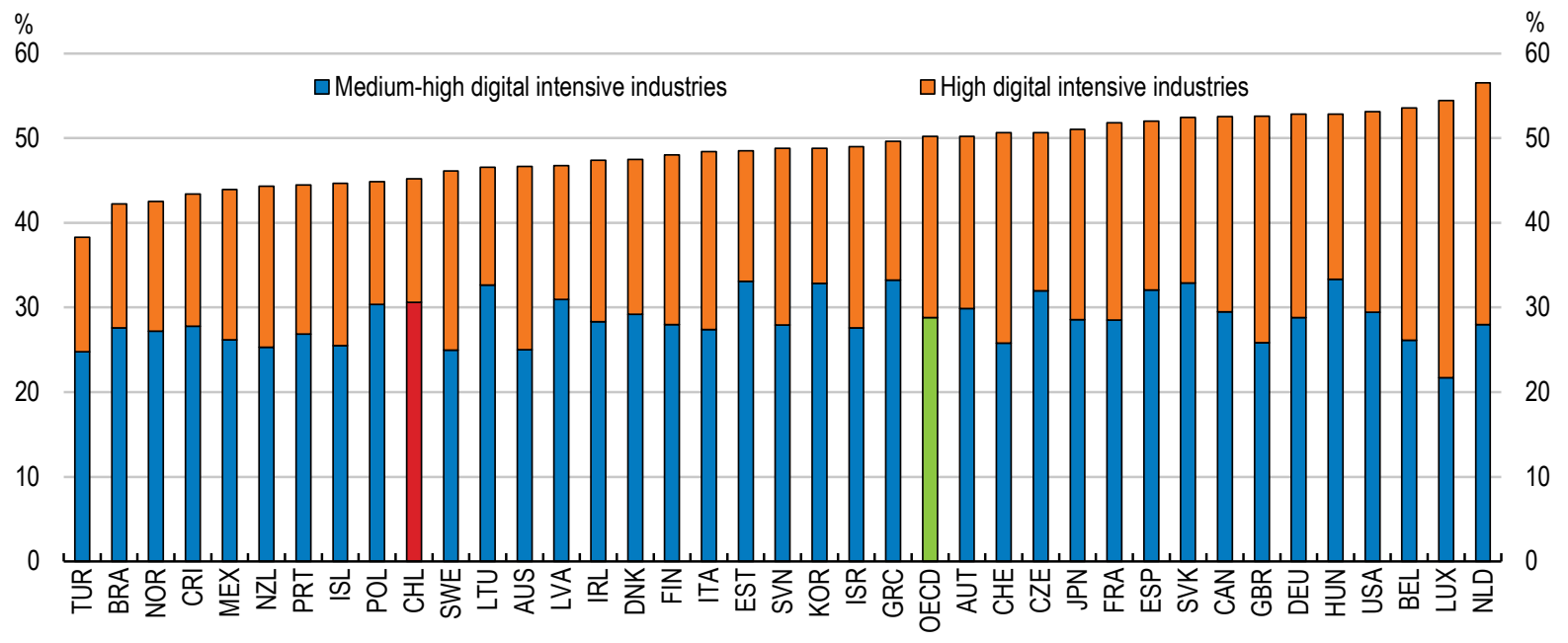

Source: OECD Going Digital Toolkit.

StatLink त्ञाज https://doi.org/10.1787/888934194162

However, the benefits provided by digitalisation could be associated to some risks. The Chilean labour market is experiencing polarisation, i.e. the share of middle-skilled jobs has decreased relative to the share of workers in high and low-skilled occupations (Figure 24, Panel A), as in other emerging economies and many advanced economies (Alonso Soto, 2019[60]). This effect was not accompanied by an increase of the share of middle-pay workers, because an occupational shift led to an increase in the propensity of different occupations to pay medium wages (Figure 24, Panel B). The raise in the share of middle-paid jobs reflects that people with high skills are increasingly being paid middle wages. Polarisation can be exacerbated by digital transformation if not everyone has the skills needed to take advantage of the opportunities digitalisation could deliver. 
Figure 24. The Chilean labour market shows signs of polarisation

A. Percentage points change in share of working adults in each skill group, mid-1990s to mid-2010s
B. Percentage point changes in the share of jobs by level of pay between 2006 and 2016

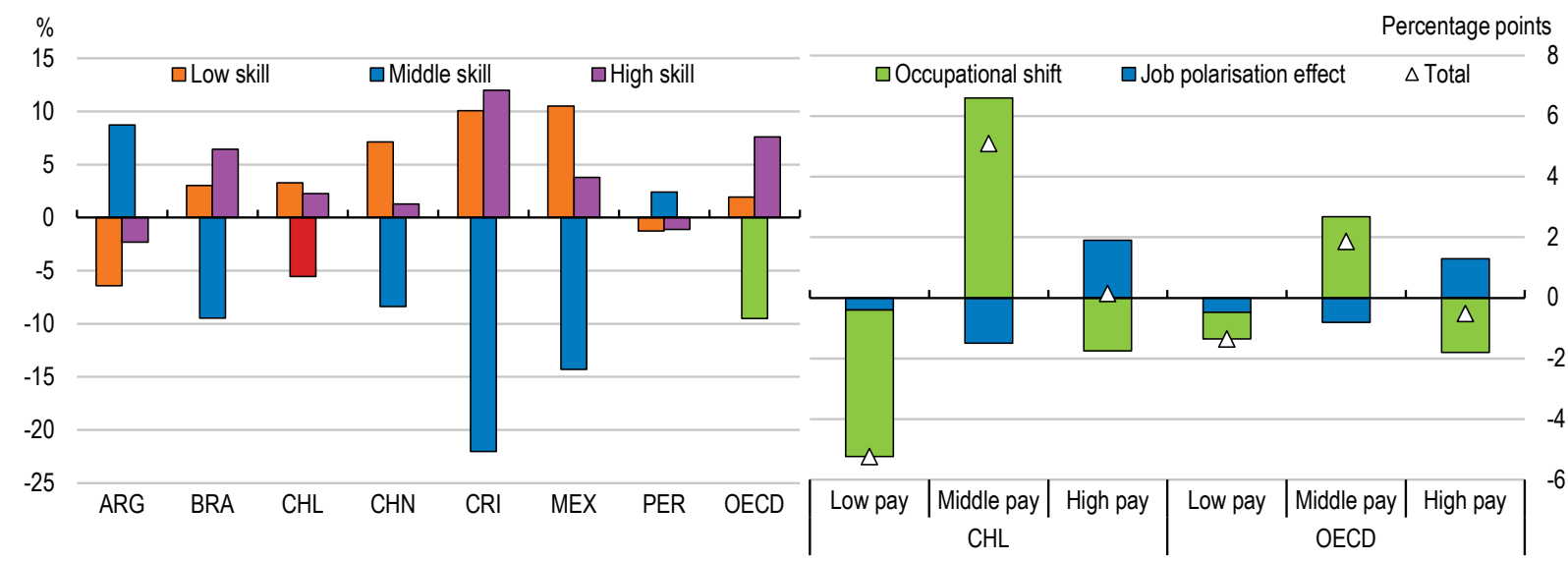

Note: In Panel A, high-skilled occupations include jobs classified under the ISCO-88 major groups 1, 2, and 3, that is, legislators, senior officials, and managers (group 1), professionals (group 2), and technicians and associate professionals (group 3). Middle-skilled occupations include jobs classified under the ISCO-88 major groups 4, 6, 7, and 8, that is, clerks (group 4), skill agricultural and fisheries workers (group 6), craft and related trades workers (group 7), and plant and machine operators and assemblers (group 8). Low-skilled occupations include jobs classified under the ISCO-88 major groups 5 and 9 , that is, service workers and shop and market sales workers (group 5), and elementary occupations (group 9). OECD refers to the unweighted average of 23 member countries. In Panel B, low-paid jobs are those paying less than two thirds of the median wage, while high-paid jobs are those paying more than 1.5 times the median wage. OECD refers to the unweighted average of 31 member countries. The time period covered is $2006-2015$ for Chile.

Source: OECD 2019 Employment Outlook.

StatLink 제 SR https://doi.org/10.1787/888934194181

Some jobs will be created, some jobs will be replaced, and many jobs will be transformed (Figure 25, Panel A). Digital transformation is dramatically transforming the demand for skills, occupations and tasks performed by workers (Grundke et al., 2018[61]; OECD, 2019[62]; Weller, Gontero and Campbell, 2019[63]). More than half of Chilean workers are in jobs likely to be impacted by automation, or that will face significant changes, affecting the middle- and low-class households disproportionally (Figure 25, Panel B). Even when taking into account informality as an activity of subsistence, almost $24 \%$ of total employment is likely automatable in Latin America, with this share being higher at $36 \%$ in Chile (Weller, Gontero and Campbell, $2019_{[63]}$ ). In fact, digitalisation and automation are already affecting the labour market dynamics in Chile (Box 4). Employment in jobs with high risk of automation have already decreased in the last decade and this has happened mainly in jobs that are mainly routine and manual (Figure 26). 
Figure 25. More than half of jobs are at risk of automation, affecting more low and middle-classes

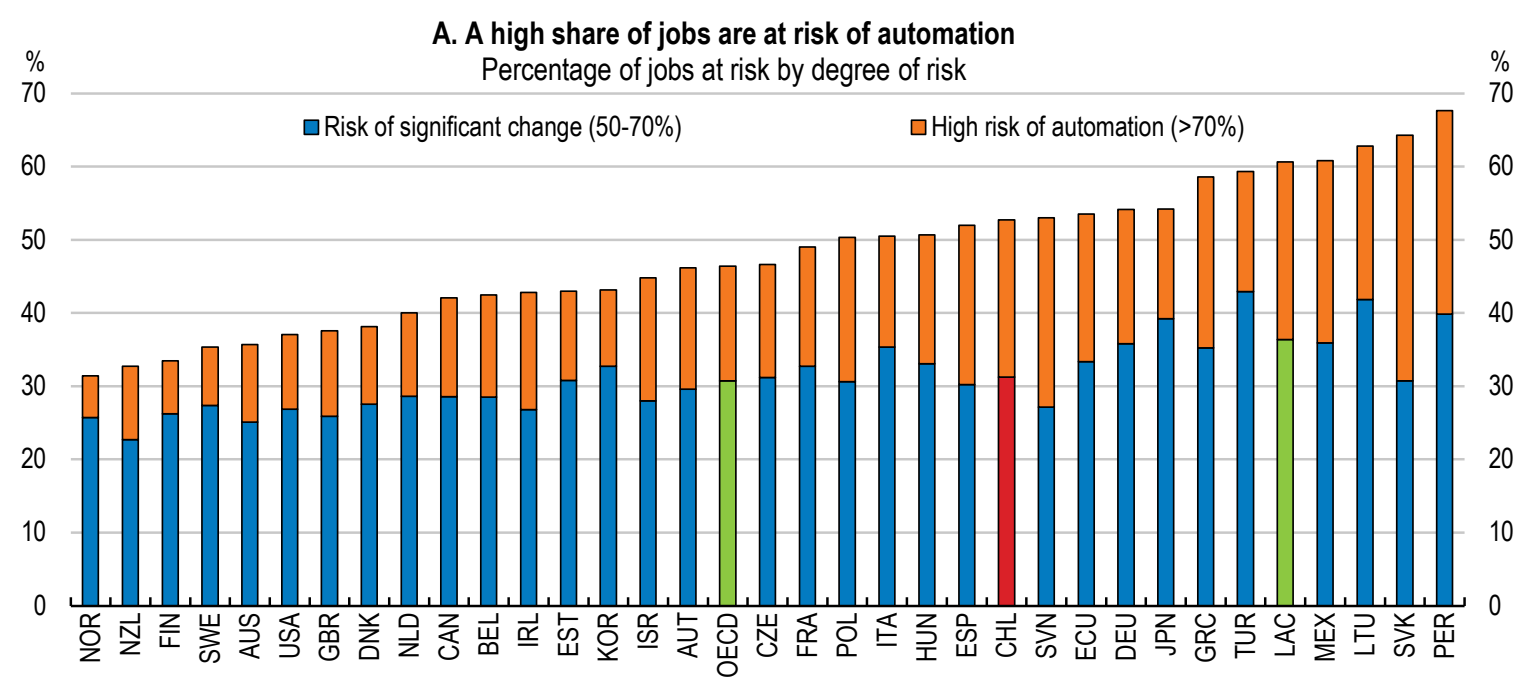

B. The low and middle class are mostly affected by the automation risk

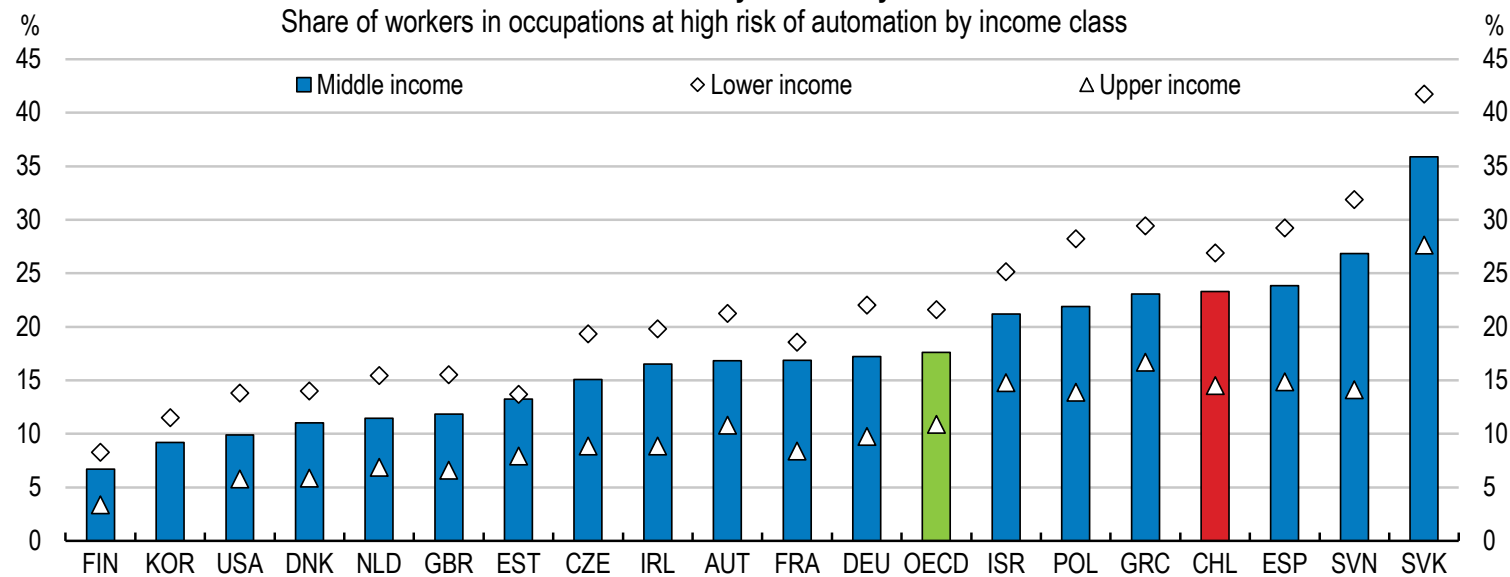

Note: In Panel B, "Lower income" households defined as households with income below 75\% the national median. "Middle income" households are households with income between $75 \%$ and two times the national median. "Upper income" households are households with income above two times the national median. The risk of automation is calculated as the average of the risks of automation by occupation, weighted by the share of each occupation in the income class. LAC refers to the unweighted average of Ecuador, Mexico and Peru. For both panels, data are from 2015 or latest year available.

Source: Nedelkoska, L. and G. Quintini (2018), "Automation, skills use and training", OECD Social, Employment and Migration Working Papers, No. 202, OECD Publishing, Paris. http://dx.doi.org/10.1787/2e2f4eea-en; OECD (2019), Under Pressure: The Squeezed Middle Class, OECD Publishing, Paris, https://doi.org/10.1787/689afed1-en; OECD secretariat calculations based CASEN 2017 for Chile and PIAAC. 
Figure 26. Employment in routine manual occupations and those with high risk of automation has decreased in the last decade
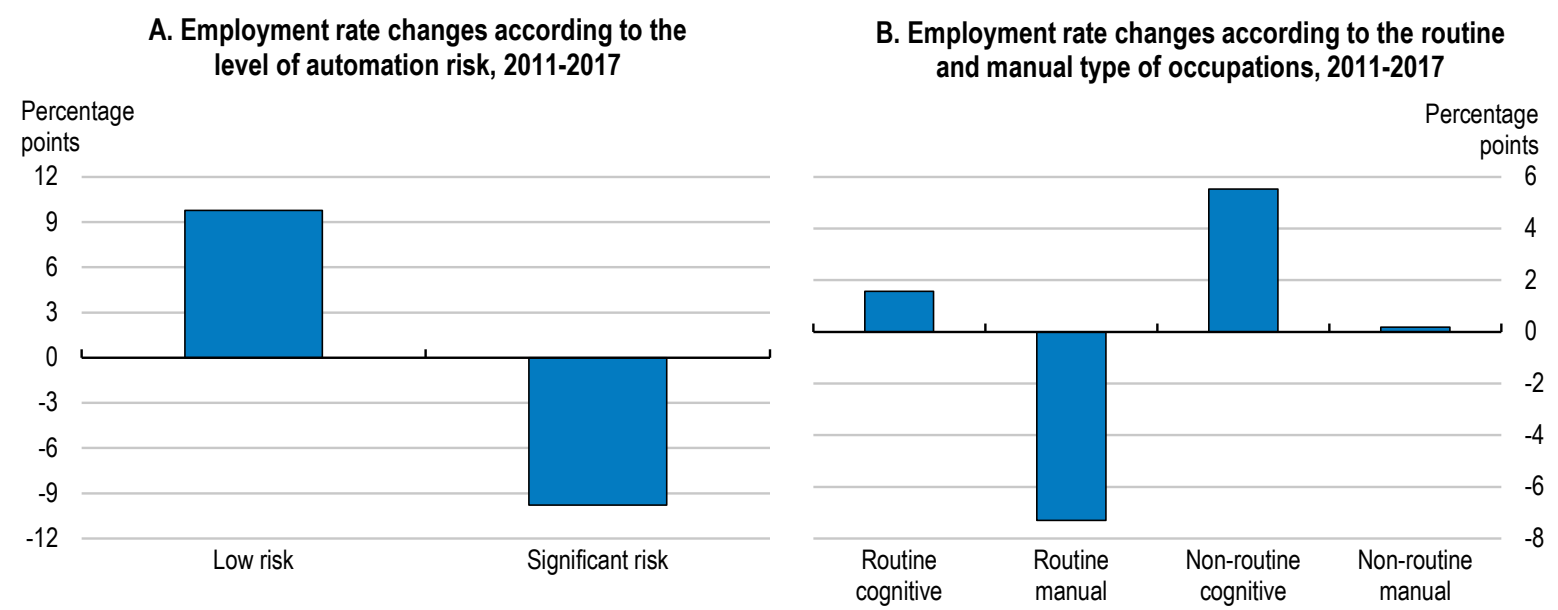

Note: The bars show changes in employment rate in each occupational classification between 2011 and 2017. The relative importance of the change for each group depends on the distribution of occupations. In Panel A: Significant risk - above 50\% probability of automation; low risk below 50\% probability of automation as defined by Nedelkoska and Quintini (2018). In Panel B: intensity of task content of occupations as identified by Marcolin et al. (2016) and Nedelkoska and Quintini (2018) using PIAAC.

Source: OECD calculations based on CASEN (2011-2017), PIAAC (2012 and 2015), Marcolin et al. (2016) and Nedelkoska and Quintini (2018).

StatLink הतist https://doi.org/10.1787/888934194219

\section{Box 4. Is the impact of digital technologies already visible in the Chilean labour market?}

Research conducted for this paper (Marköö and Garda, forthcoming[64]) investigates the impact of digital technologies on employment dynamics in Chile. The analysis uses individual labour history data from the 2015 Social Protection Survey (EPS) to observe individual month-to-month employment transitions between 2009 and 2015. Different measures at the occupational level are used to capture different aspects of digital transformation, such as the automation risk or the advancement in artificial intelligence.

The results suggest that both destructive and transformative effects of digitalisation on employment dynamics are already observable in the Chilean labour market (Figure 27 and Figure 28). Higher automation risk is associated with higher likelihood of becoming non-employed. These risks are unequally distributed among workers. For example, a 10-percentage points increase in the automation risk of the occupation increases the monthly probability of becoming non-employed by $27 \%$ of the baseline monthly probability of transitioning to non-employment for men and $32 \%$ for women. The findings also indicate that automation adversely affects highly skilled occupations, as the risk of entering non-employment increases with the educational level. This is particularly true for women. The likelihood of switching occupations increases with age. This may suggest that older individuals have difficulties adopting new technologies in their occupation, and instead need to choose to change occupations. This could imply reskilling and potential negative impact on wages. 


\section{Figure 27. Automation risk and labour market transitions in Chile}

Estimated average marginal effect of a 10 percentage point increase in automation risk on month-to-month individual transitions

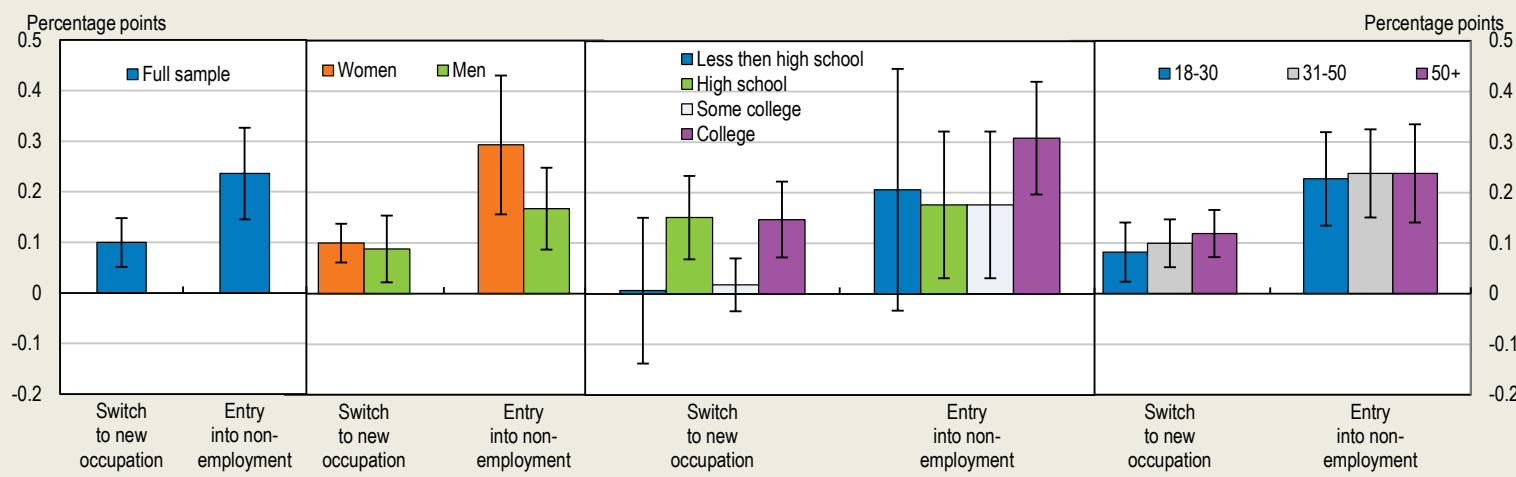

Note: The employment transitions are modelled in a random utility framework using two multinomial logit models. The dependent variable distinguishes between three choices for those in employment: i) remaining in employment in the same occupation 4 digit level (base category); ii) remaining in employment but changing occupation at 4 digit level; iii) exiting employment to unemployment or inactivity. The measure for automation risk is widely used by the OECD and has been developed by (Nedelkoska and Quintini, 2018[65]). It captures the automation risk of occupations at 2-digit level. Lines indicate the 95\% confidence interval. Estimates are obtained through a multinomial logit model controlling for educational attainment, age, age squared, marital status, gender, if the respondent has children, region and industry. To control for business cycle and seasonal effects, year and month dummies are included. Standard errors are clustered at 2-digit occupational level.

Source: (Marköö and Garda, forthcoming[64]).

StatLink त्ञाज्य https://doi.org/10.1787/888934194238

Advances in artificial intelligence seem to be associated positively with employment stability of an individual. This reflects the idea that advances in artificial intelligence are complementary to labour. One standard deviation higher score in occupational advances in artificial intelligence is linked to a lower probability of exiting employment by approximately $12 \%$ of the baseline monthly transition probability. This positive effect on employment stability increases with education and age, suggesting that individuals with higher levels of education and experience can adapt more easily to Al technologies, as a complement to their work. However, the likelihood of switching occupations also increases with higher Al advancement, notably for highly educated or young individuals.

\section{Figure 28. Artificial intelligence and labour market transitions in Chile}

Estimated average marginal effect of a 1 standard deviation increase in advances in Al on month-to-month individual transitions

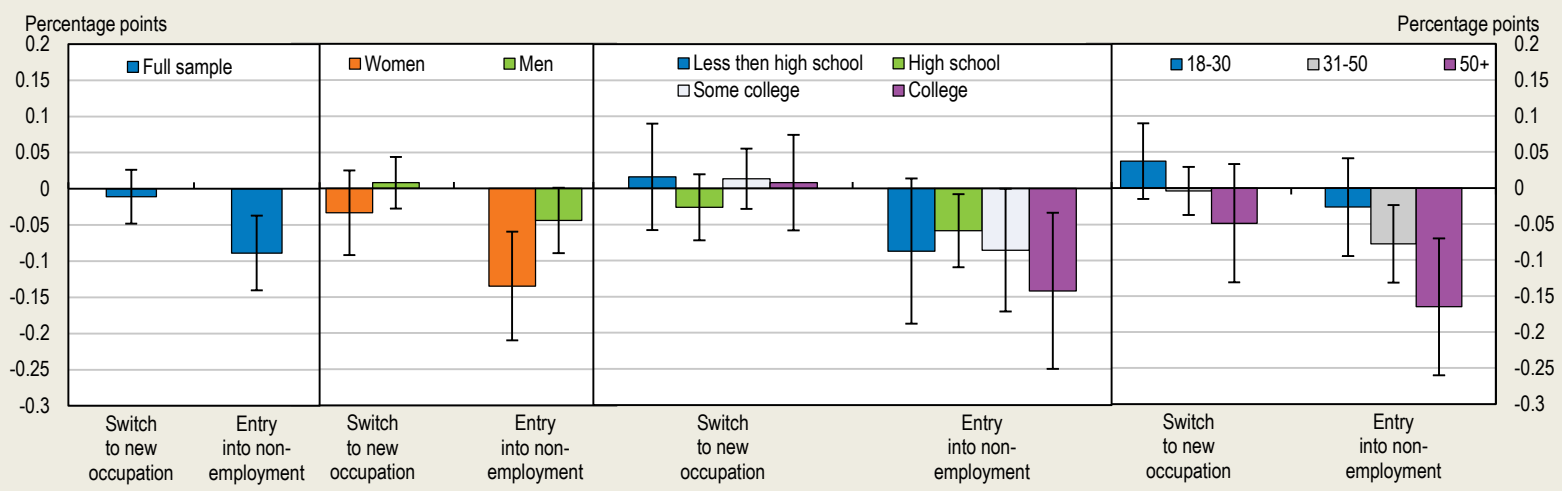

Note: See note previous figure. The measure for advances in Al is developed by (Felten, Raj and Seamans, 2019[6]) and estimates recent advances in artificial intelligence of occupations at 4-digit level. Lines indicate the $95 \%$ confidence interval. Standard errors are clustered at 4-digit occupational level. Source: (Marköö and Garda, forthcoming[64]). 


\section{Box 5. The impact of digital transformation on wages in Chile}

An analysis conducted for this study investigates the impact of digital technologies on wage dynamics between 2015 and 2017. The study employs measures reflecting different aspects of digital technologies (see Box 4) and uses data from household surveys (CASEN) between 2013 and 2017 to observe within-occupation changes in wages at the regional level.

The analysis provides evidence that wages of low-income and high-income occupations are negatively affected by the automation risk (Figure 29). A 10-percentange point increase in the occupational automation risk leads to a reduction of 3-percentage points of the median wage for low-income occupations, and a 10-percentage point for high-income occupations. However, both low-income and high-income occupations also seem complements to new digital technologies, such as artificial intelligence, increasing wages due to higher productivity at the firm level. On the contrary, middleincome occupations are negatively affected by the advancement of Al. These findings suggest that productivity-enhancing digital technologies, such as artificial intelligence, mostly affect and largely complement high-skilled workers relying on non-routine tasks (Felten, Raj and Seamans, 2019[66]).

\section{Figure 29. Automation risk leads to lower wages for the low-income, but artificial intelligence has a positive impact}

\section{A. Impact of a 10 percentage point increase in automation risk on wage growth}

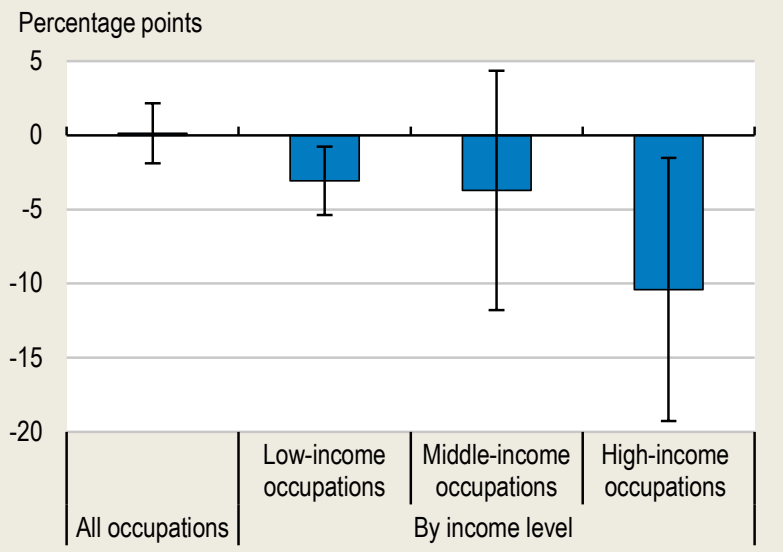

B. Impact of one standard deviation increase in advancement in Artificial Intelligence on wage growth

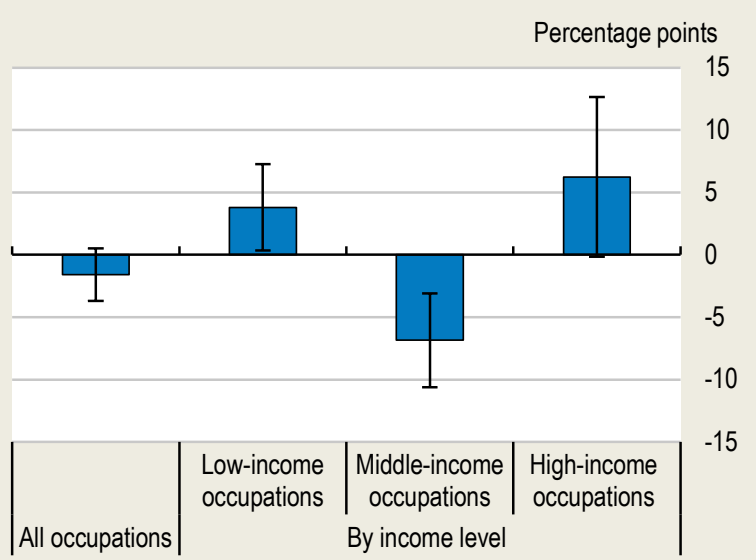

Note: The bars show the impact in percentage points of median wage growth 2015-17. Wage growth is calculated at the region-occupational level. The measure for automation risk is widely used by the OECD and has been developed by Nedelkoska and Quintini (2018). It captures the automation risk of occupations at 2-digit level. The second measure is developed by Felten et al. (2019) and estimates the advancement in artificial intelligence of occupations at 4-digit level. Occupations are classified as low-, middles- and high-income based on terciles of the median annual income for an occupation in 2013. Estimates are obtained through an ordinary least squares regression controlling for lagged wage growth (2011-13). Standard errors are clustered at the regional level.

Source: (Marköö and Garda, forthcoming[64]). 


\section{Promote job quality to cope with emerging forms of work}

Across the OECD, the recent wave of digital transformation and technological change has been likely at least one of the drivers increasing job turnover (OECD, 2019[21]). There is an increasing trend of workers who, throughout their careers, hold more jobs, each of them for shorter periods, often with intermittent and different hiring modalities (LinkedIn, 2016[67]). These changes foreshadow the challenges to employment and social protection systems, pension schemes, and the training system.

Firms are changing the way they hire and organize work within a firm (OECD, 2019[21]). Some firms are increasingly hiring external contractors, temporary staff or self-employed to address their skill gaps (WEF, $\left.2018_{[68]}\right)$. Many companies are also working on projects and hire workers to perform specialized tasks and are using more flexible work, remote offices and decentralizing operations, trends that are likely to deepen with the pandemic. The platform economy and its rapid expansion (Figure 30) is a clear example of the trends. Although no official data exist, around 150 thousand workers (1.7\% of employment) participate in the platform economy in Chile according to figures provided by the Labour Minister in an interview with CNN in February 2019.

Figure 30. Online platforms have increased at a fast pace in Chile

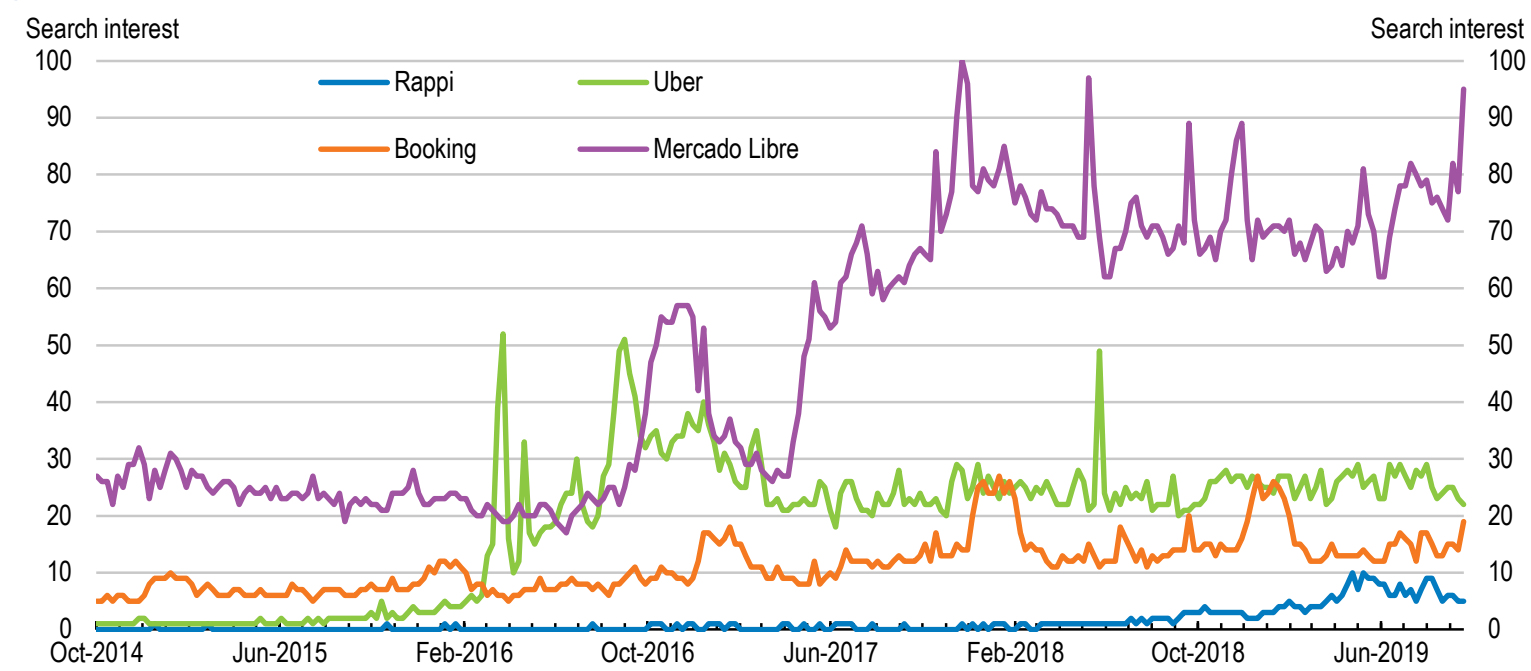

Note: The numbers reflect the search interest in relation to the maximum value of a chart in a given region and period. A value of 100 indicates the maximum popularity of a term, while 50 and 0 indicate that a term is half popular in relation to the maximum value or that there was not enough data for the term, respectively.

Source: Google Trends.

StatLink ज्ञाs https://doi.org/10.1787/888934194295

Governments should aim to ensure that differences in rights of employment, social protection, and access to training are reduced across different contract types. Some of the new jobs in the platform economy are thought to reduce job quality because they tend to lack or have limited access to training, lack employment and social protection and have limited benefits and rights (OECD, 2019[21]). Many of these workers find themselves classified as self-employed, even though they share some characteristics and therefore vulnerabilities with employees. Yet, because they are classified as self-employed, these workers will not have access to the same rights and protections as employees. At the same time, not all of these jobs necessarily equate to poor quality employment. Those may allow both employers and workers to escape the constraints of a "one-size-fits-all" approach and find arrangements that are in the best interest of both. For example, many high-tech professionals sell their services as independent contractors (OECD, $\left.2019_{[21]}\right)$. The challenge for governments is to ensure that all workers, regardless of contract type, have access to adequate rights and protections, and also that there are no abuses of the existing legislation (e.g. when companies falsely classify workers as self-employed in order to escape regulatory and fiscal commitments). 
Non-standard employment arrangements are not new in Chile (Figure 31). The share of temporary contracts, although decreasing since 2012, is the highest among OECD countries. Self-employment, often associated with low access to protection or social benefits and low productivity, is high at $26 \%$ of total employment in 2010-18. Informality, as measured by the lack of social security, is high at $29 \%$ of employment, although among the lowest in the LAC region. The share of informal wage earners at $16 \%$ has been decreasing, explained partly by the rise of other non-standard employment arrangements, such as outsourcing or self-employment (Perticara and Celhay, 2010[69]; Ministry of Labour, 2017[70]). Youth, women and low-skilled hold more frequently non-standard jobs.

\section{Figure 31. Self-employment, temporary and informal jobs are prevalent in Chile}
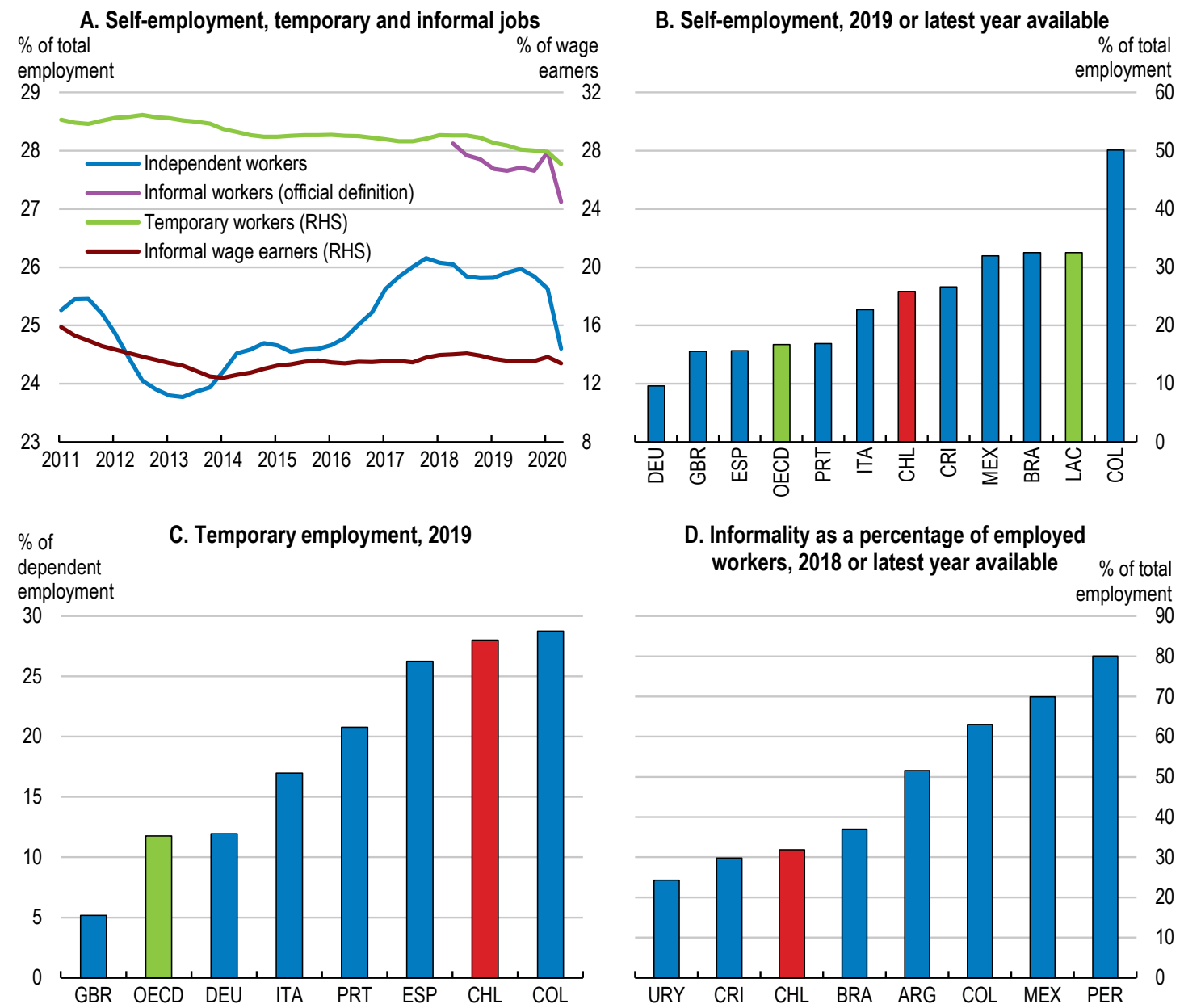

Note: In Panel A, data are 4-quarter moving averages. The official definition of informal employed includes dependent and independent workers with informal occupations. It includes: dependent workers who do not have access to social security (pensions and health); independent workers who are owners of an informal company or business (not registered in the internal tax service) or who engage in an activity classified as informal; and employed persons classified as unpaid family workers. Official informal employment figures are only available from September 2017. In Panel B, data refers to the population of 15 years old and above. LAC refers to the unweighted average of Brazil, Colombia, Costa Rica and Mexico. OECD refers to unweighted average of 34 member countries. In Panel D, informal workers are defined as not contributing to the pension system.

Source: Data for Chile for Panels A:C are from OECD calculations based on the Encuesta Nacional del Empleo (ENE) from the Instituto Nacional de Estadísticas, Chile; OECD, Annual Labour Force Statistics database; OECD, Labour Market Statistics database; IADB SIMs database.

StatLink त्ञाs https://doi.org/10.1787/888934194314 
Platform workers are heterogeneous and sometimes difficult to classify as salaried or autonomous. Yet some consensus seems to be emerging that many of these workers lack basic rights and protection, and this has become even more evident during the COVID-19 crisis. Many countries in Europe are moving in the direction of providing a minimum floor of rights and guarantees for all platform workers. Labour market regulation should seek to provide a set of rights to all workers, regardless of their employment contract, minimizing the differences between different types of jobs (OECD, 2019[21]).

The employment status acts as a gateway to various worker rights and protections, including employment and social protection, but also access to training. There is a need to strengthening the penalties for misclassification (between the self-employed, usually informal, and employees, for example), reducing any incentives for firms and workers to misclassify employment relationships and enforcing it (OECD, 2019 ${ }_{[21]}$ ). For workers who remain in the grey zone, where there is genuine ambiguity about their employment status, the government should seek to extend rights and protections.

Fostering hiring under permanent standard contracts and avoiding informality could be a way of avoiding misclassification of workers. There are a number of programmes in Chile promoting formalisation that could be enhanced. For example, the youth employment subsidy (Subsidio al Empleo Joven), targeted at workers aged 18-24 years-old from the $40 \%$ most vulnerable households, gives also a subsidy to firms hiring these young workers. The programme also covers self-employed workers who are up-to-date with pension contributions. Unfortunately, the programme's coverage has been recently reduced and is planned to benefit 280 thousand youth, more than 42 thousand less than in 2018. These wage subsidies are important to promote formality for youth (Centro de Microdatos, 2012 [71]; Bravo and Rau, 2013 [72]) since the first job and its working conditions largely determine the employment and career paths of young people.

Authorities approved, as a response to the social events of end of 2019 , the minimum guaranteed salary, which works as an employment subsidy for formal low-income workers. The subsidy is for formal workers with nominal income below CLP 380 thousand and is to benefit 480.2 thousand workers in 2020. The subsidy could create incentives for workers to become formal (Almeida, Orr and Robalino, 2014[73]), but at the same time create incentives for firms to maintain low wages. The measure will need to be carefully evaluated and adjusted as necessary.

Policies promoting quality jobs and protecting informal workers would help promoting formality. They include introducing progressivity into social security contributions, subsidising low-income workers; adapting contributions for independent workers (e.g. frequency, payment method, simplified tax system); reducing administrative cost and burden associated with formal status.

The platform economy and jobs can be used to reduce informality (Alonso Soto, 2020[74]). The ability to monitor the data (traceability) offered by the digital platforms is a great promise: all transactions are recorded, and the workers receive their income via bank transfer (Alaimo, Chaves and Soler, 2019[75]). In this aspect, the platforms are a source of information essential to make workers visible and structure social protection schemes that suit the particular circumstances. Streamlining regulations on online job platforms to provide platforms and workers with incentives to share data with tax and labour authorities could help reduce informality.

Regulation of how much algorithms can do and decide for workers is needed to protect platform workers (OECD, 2019[21]). Platform workers do not have one employer as traditional workers do. Instead, it is an algorithm that regulates employment (Alaimo, Chaves and Soler, 2019[75]). Customer evaluations, acceptance or rejection of an order and delivery times, among others, are some of the indicators automatically measured by artificial intelligence algorithms and used to give or not employment. The European legislation makes mandatory that the person responsible indicates the reasons that led to that decision (the right to an explanation). In this sense, regulations have a lot to contribute, promoting the decisions affecting work are resolved by people, and that the artificial intelligence is under human control. The right not to being discriminated against by an algorithm deserves special attention. 


\section{Improve social protection to leave no-one behind}

The existence and the growing trend of more flexible employment modalities or non-standard employment relationships implies that labour market regulations and social security systems need to adapt to leave noone behind. For this, regulations must, where appropriate, reduce this distinction between wage-earning and self-employed, and between formal and informal, and incorporate the new ways of working.

Digital transformation could intensify existing contributory gaps in the pensions and social protection because of more job changes and more unemployment spells. In Chile, average-wage workers who experience a 5 -year unemployment spell during their career face a pension reduction of almost $15 \%$ in mandatory schemes compared to the full-career scenario (OECD, 2019 $\left.{ }_{[76]}\right)$. It is necessary to include atypical workers with fluctuating income and/or intermittent work so that they can be covered against risks, such as illness, unemployment or retirement.

Aware of these challenges, authorities are increasing the coverage of the pension system for non-standard workers. Contributions of independent workers to social protection systems who issue receipts, accounting to $7.5 \%$ of the labour force, was made mandatory starting in 2019 , with a gradual increase in contributions from $10 \%$ in 2018 to $17 \%$ in 2028, except for older workers and low income earners. In the first few years, it will be possible to contribute for only a fraction of the taxable income. Additionally, a draft bill is in Congress to regularise the social protection of those providing services on digital and intermediation platforms. The bill defines this group of workers as independent, making mandatory for these workers to issue receipts, and that the platform withhold the corresponding taxes and social security contributions. The bill would also expand the coverage of the pension contributions while unemployed for those under private individual unemployment insurance accounts, while today this is only the case for those under the solidarity pillar.

Fully including all non-standard workers in mandatory pensions in the same way as standard workers limits the financial incentives employers and workers might have to misuse non-standard employment (OECD, $2019_{[76]}$ ). International experience indicates that social security contributions should be harmonised across forms of employment as much as possible to decrease incentives to hiring on non-standard work (OECD, $2018_{[77]}$ ). If lower mandatory pension contributions for the self-employed are used as an instrument to promote self-employment or to support those in low-earning activities, resulting lower entitlements should be avoided by topping up the lower implied contributions through subsidies, at least for low earners. Appropriate compliance measures might be needed to ensure enforcement.

Encouraging voluntary savings for retirement is needed to get better pensions and digital technologies can be exploited with this objective. There are pilot exercises in the region that could serve as an example. The pilot of savings plan for Cabify drivers in Peru is a good example. The project gives access to drivers of Cabify to an automatic saving option through the digital platform. Since their income is accumulated on the platform, workers have the option to save through the application. The Smart and Flexible Savings Plan takes into account the variation in workers' incomes and allows drivers to save, for example, $10 \%$ of the income above a certain level threshold and not to contribute when their income is below this threshold (Alaimo, Chaves and Soler, 2019 ${ }_{[75]}$ ). Other innovative ways to encourage voluntary savings of workers should be thought. Chile has already a pilot example with Übank, a Chilean start-up, which developed an application that allows people to save automatically based on a set of rules, defined by themselves. Results show that it has been successful raising savings for retirement (FIAP, 2018[78]).

An effective social safety net would help individuals cope with transitions from one job to another. The Chilean unemployment benefit system is based on individual accounts with complements from an insurance fund (Solidarity Fund), and assures that workers have savings in the event of losing their jobs (Hartley, van Ours and Vodopivec, 2011 [79]). However, the coverage and benefits of the unemployment system remain limited, in part due to self-employed workers, but also because of the short duration of employment contracts and their high turnover (Huneeus, Leiva and Micco, 2012[80]). 
Chile has a large share of workers on fixed-term contracts with high rotation, a trend that could be amplified by digital transformation. Two out of every three workers that claim unemployment benefits were on a fixed term contact, and only $15 \%$ accessed the Solidarity Fund. Moreover, only $50 \%$ of employees that terminate a contract in a year have enough contributions in their accounts to access benefits. Also, $50 \%$ of the workers under fixed-term contracts have non-contributing periods lasting more than three months in 2015, which impedes their access to the Solidarity Fund (Sehnbruch, Carranza and Prieto, 2019 ${ }_{[81]}$ ). Reducing the required minimum contribution periods would increase coverage of vulnerable jobseekers, and allow the system to better protect vulnerable workers under short duration of contracts.

In December 2019, after the social unrest, and again because of the pandemic, authorities have temporarily improve protection for unemployed workers affected by the social crisis. After the social unrest the changes included the increase of the amount of payment in the two (three) first months for temporary (permanent) workers, the reduction of the required minimum contribution periods from 12 to 10 (6 to 5) for permanent (temporary workers), and from 12 to 10 months for accessing the Solidarity Fund. It also introduces the possibility of negotiating a $15-50 \%$ reduction in working time for a maximum period of five continuous months, while receiving a complement from unemployment benefits. These are welcome measures and should become permanent, at least when the economy or the unemployment rate surpasses certain thresholds.

\section{Chile is facing an important training challenge}

Chile needs a comprehensive lifelong learning strategy to face the challenges of digital transformation and to ensure that all workers, particularly the most vulnerable, have adequate opportunities for retraining throughout their careers. An efficient adult lifelong learning system should help workers to regularly update, upgrade, and sometimes even acquire entirely new skills, facilitating labour mobility and responding to the changing tasks and skills (OECD, 2019[21]; OECD, 2019 [82]). This is even more important in the context of population ageing, where the majority of the workforce has already left initial education. This adult learning provision must also become more flexible and less tied to the traditional model of employer-provided training, accompanying the emergence of more flexible labour markets.

Participation in training is relatively high in Chile, but inclusiveness of the system is poor (Figure 32). Those who need training the most, train the least: low skilled, workers in vulnerable households, out-of-work individuals, those whose jobs are most at risk from automation, as well as non-standard workers train the least (Figure 33). In addition, training is not always of good quality and insufficiently aligned to the needs of the labour market (CNP, 2018 $\left.{ }_{[19]}\right)$. Recent improvements adding requirements of results (such as job placement, higher wages or formalisation depending on the program) to the training offer go in the right direction.

Chile lacks a lifelong learning system with a clear national regulatory framework and a national plan, as already highlighted in the previous Economic Survey of Chile (OECD, 2018[1]). The life-long learning system is formed by: firm-provided on-the-job training (channelled by a tax credit: Franquicia Tributaria), training programs targeted at vulnerable groups (e.g.Capacitación en Oficios) or the middle-class (e.g. Relnvéntate, an upskilling programme targeted at unemployed from the middle-class) and employment subsidies. Although the Ministry of Labour is responsible for training policy, it does not have a specific unit responsible for the design, formulation, monitoring and evaluation of these policies (CNP, 2018 ${ }_{[19]}$ ). SENCE, the state agency of training and employment in charge of the main training programmes targeted at vulnerable groups and active labour market polices, which depends on the Ministry of Labour, concentrates the largest number of beneficiaries for training programs, $77 \%$ of the total in 2016 . SENCE mission is to contribute to the increase of national productivity, promoting training, both in firms (through the tax credit, Franquicia Tributaria) and in the vulnerable people (through targeted programmes). The system is fragmented, leading to a diversity of programs with similar purposes and target populations. Agencies lack a mechanism to coordinate with each other, resulting in dispersion of unconnected efforts 
among different public agencies. One clear exception to this is the development of the national qualification framework, under development, a concerted effort led by the Ministry of Education, in collaboration of the Ministries of Labour, Economy and Finance.

\section{Figure 32. Participation in training is high in Chile}

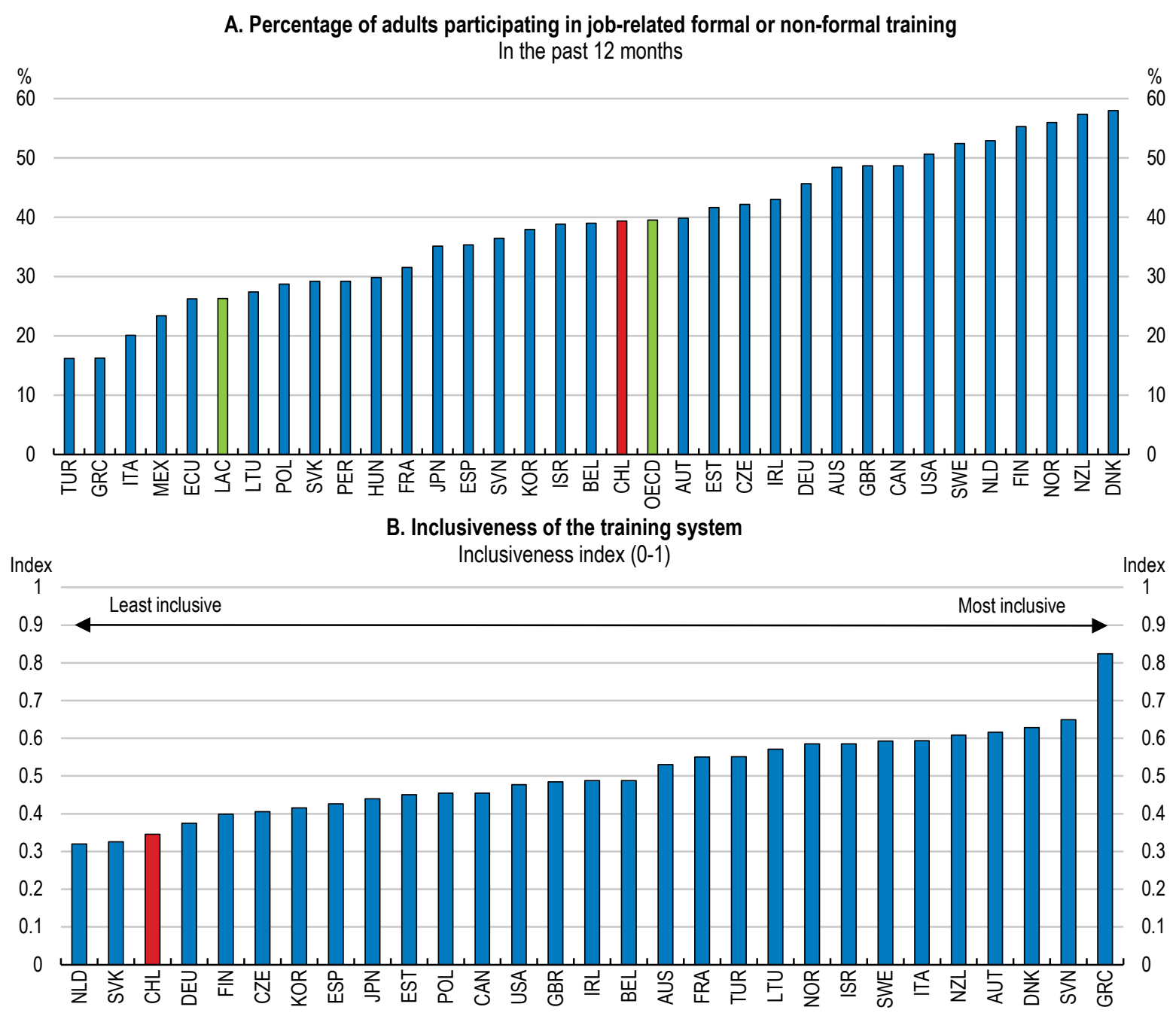

Note: In Panel A, LAC refers to the unweighted average of Ecuador, Mexico and Peru. OECD refers to the unweighted average of 31 member countries. In Panel B, the index ranges between 0 (least inclusive) and 1 (most inclusive). For both panels, data are from 2015 or latest year available. Panel $B$ is based on the Priorities for Adult Learning (PAL) dashboard that highlights the importance of providing inclusive learning opportunities in particular for those groups most in need of up- and re-skilling. It features indicators measuring participation gaps between disadvantaged adult learners and their more advantaged peers, where disadvantages may relate to socio-demographic characteristics of adults or their employment and contractual situation. It includes old-age, gender, low-skill, low-wage, unemployment, long-term unemployment, temporary workers and SME participation gaps.

Source: OECD Priorities for Adult Learning Dashboard, using PIAAC data; OECD publication: "Getting Skills Right, Future-Ready Adult Learning Systems".

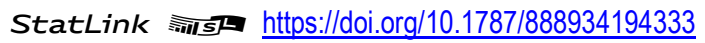

Franquicia Tributaria, the tax credit to firms who send workers on training with certified institutions, is one of the main training programmes, equivalent to around $28 \%$ of public spending on training in 2019 . Two out of three trainees do so within the tax credit, whose training programs are short lasting less than 40 
hours, with an average of 21 hours (CNP, 2018 $\left.{ }_{[19]}\right)$. This programme benefits mostly large firms, which tend to already have less vulnerable, highly educated workers (Larrañaga, 2011 [83]; Rodriguez and Urzúa, 2012[84]) and does not reach the self-employed, which have accounted for a large share of job creation in the latest years. The tax credit has been found to be not effective due to the short duration and lack of relevance of training programmes. The programme also lacks the requirement of certification of courses, and problems in the design of incentives for firms, suppliers and intermediaries (CNP, 2018[19]; Bravo, García and Schlechter, $\left.2019_{[85]}\right)$. Most training programmes are fundamentally theoretical programs, and measure their success by attendance and teaching hours. Recently, in a welcome move, modifications to the scheme allow firms to train workers before starting to work in the firm or after with the objective of increasing incentives for unemployed to undertake training courses.

\section{Figure 33. Most vulnerable workers receive less training}
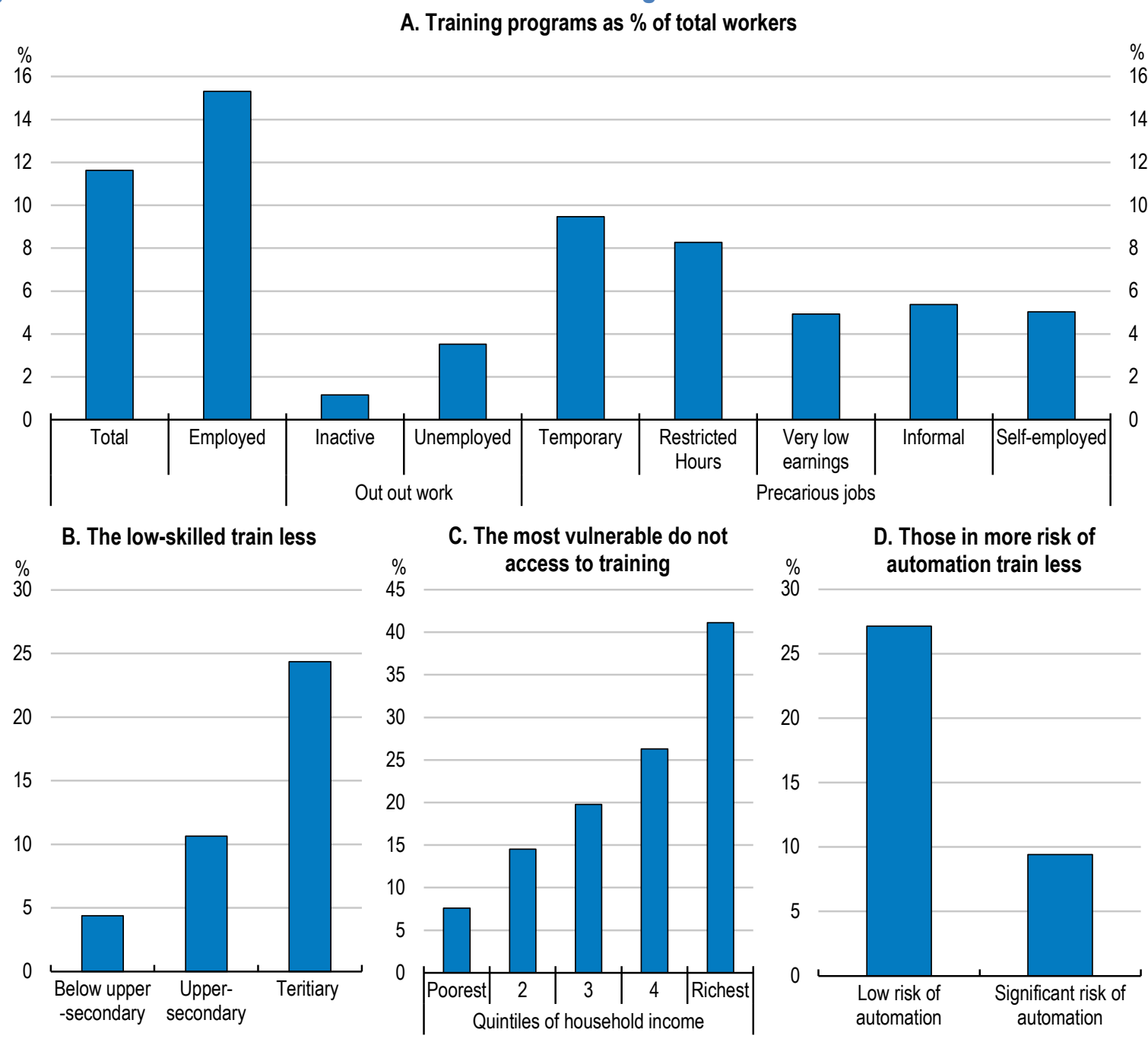

Note: Year 2017. Workers participating in training in the last 12 months.

Source: OECD calculations using CASEN (2017).

StatLink הत्ञsh https://doi.org/10.1787/888934194352

Another $30 \%$ of public spending allocated to SENCE in 2016 is targeted to the most vulnerable, including women, youth and low-skilled workers. These types of training programmes have proven to be modestly (but persistently) effective in terms of the quality of the jobs found in the region (IDB, 2015[86]). More workbased training could be introduced to help beneficiaries get relevant experience. Also, better information 
on the type of skills needed or demanded by the market as well as on the variety and quality of the courses offered by providers is key for the success of these programmes.

Aware of the challenges, the authorities have submitted a reform to modernize SENCE. The bill seeks to finance courses through SENCE under the requirement of certain employability measures. It also seeks to enhance the tax credit, by introducing a minimum co-payment of $20 \%$ for all courses. This should incentivize firms to choose higher quality courses due to the greater control in expenses. The reform also has the objective to increase quality and alignment of the training offer, including the requirement of formulating programmes based on available information on required competencies and making programme evaluation mandatory. As part of the bill, and in order to include small businesses, funds assigned through bidding, will allow the design of specialized training programs in different sectors for small business associations.

A full revision of the tax credit and better aligning training courses with labour market needs is required for a well-functioning adult training system. The productivity commission has recommended redirecting all public resources for training, including those of the tax credit, to a training fund (CNP, 2018 $\left.{ }_{[19]}\right)$. The focus should be on those that need training the most, unemployed, inactive and those working on non-standard contracts and vulnerable workers. Training programmes should assure the development of skills in occupations that are expanding, but with insufficient supply in the market. All training courses would require skills certification related to the national qualifications framework and could be part of the VET (Vocational educational and training) system in order to allow individuals to follow a learning path.

Sustainable financing is key for an efficient adult training system (OECD, 2019[82]). To encourage firms to invest in training of their workers and promote continuous learning and skills development opportunities, Chile could direct resources to the training funds collected from training levies imposed on employers through the pay-roll. Examples of training funds can be found in Italy or France (OECD, 2019[87]). By way of example, the contribution rates are equal to $0.8 \%$ in Ireland, up to $1 \%$ in France, $1.5 \%$ in Hungary, up to $2 \%$ in the Netherlands, and up to $2.5 \%$ in the UK (OECD, $2019_{[88]}$ ). In some countries (e.g. the Netherlands; France) training funds' resources include, on top of employers' mandatory contributions, also employers' voluntary contributions, employers' sectoral contributions negotiated through collective agreements, government funding, and/or European funding.

Encouraging small firms to participate and train their workers and make sure vulnerable workers have access to training opportunities is paramount to upskilling the Chilean workforce. Contribution rates of training levies can vary depending on the firm size or sector. Some countries have exempt, or reduce, contributions paid by SMEs encourage them to take up training levy schemes. For example, In France, training levies are $0.55 \%$ for firms with less than 10 employees, and $1 \%$ for larger firms. in the case of France, all workers have a personal training account valid from when they first join the labour market until they retire and an employee who changes jobs or alternates between work and unemployment retains his or her right to training. The individual learning account provides more generous credits to the low-skilled. Off course, for training funds to work well access to quality and relevant training is key (OECD, 2019[82]). In France, courses must be training programmes awarding a professional qualification which meet the anticipated needs of the economy in the short or medium term and which benefit the employee by safeguarding his or her career path. The Government establishes a set of quality standard criteria to which all training providers need to comply to in order to be able to access funding by training funds and other public financing bodies.

Access to training for self-employed and platform workers should be strengthened. Although SENCE has programmes targeted at vulnerable and middle class groups, including self-employed, dependant and unemployed people, participation should be ensured. Usually, the cost of training is a major barrier to train for own-account workers (OECD, 2019[82]). This is not surprising, considering that own-account workers often have no or limited access to public financial support for training, typically conceived for employees or the unemployed population. Those who work regularly for the same employers are also less likely to 
receive employer-sponsored training, as employers tend to privilege investment in the skills of standard employees. Financial incentives should be in place to help these workers get training and access to the training funds would be key. In France, since January 2018, entitlements to the individual learning account has been extended to independent workers.

Efforts to better link training to labour market needs in coordination with employers are warranted. A very good example is the programme "Talento Digital", launched recently by the Government. This is a publicprivate effort to develop digital skills mainly for unemployed and inactive, women and other vulnerable groups. Feedback from national skills anticipation and assessment exercises to understand better skill needs and how these match the skills of the workforce would be valuable for the creation and update of the training offer. Furthermore, a systematic assessment of the labour market impact of programmes should be put in place. SENSE evaluates periodically all the agencies' programmes in terms of employability, and even if there are some experiences with impact evaluations, rigorous evaluation mechanisms should be implemented to identify what works better for firms as well as workers, particularly in terms of earnings quality and job security. The emphasis should be on ensuring that resources are channelled towards programmes that proved to be effective in helping people gain employment or retrain their skills as needed.

\section{Achieving sustainable and reliable digital infrastructures}

\section{The momentum on digital government must continue}

Governments have little choice but to provide the necessary leadership in using data and technology to maximise the potential of the digital transformation for improving social well-being. Digital technologies can have a substantial impact on government's capacity to effectively design and implement policies, and to be transparent and accountable in delivering outcomes and outputs. Not only can they enhance civil servants' productivity, but also they can significantly change how governments plan and deliver services, making them more user-driven, more convenient to access and tailored to needs i.e. to design, develop, deliver and monitor public policies and services centred around people and user needs (citizens and businesses). Through the improvement of data management and processing, digital technologies can also help turn data into opportunities producing knowledge for evidence-based policy making, effective monitoring of implementation and scaling up of "what works". However, reaping the full benefits of digital technologies requires a solid governance framework to spur a coherent approach across the public sector and equal access for all citizens to digital services.

Chile has continuously demonstrated its commitment to making its digital ambitions a reality (OECD, 2019 ${ }_{[89]}$ ). The fight against COVID-19 pandemic is demonstrating authorities' capacities to use digital technology, for example with the development of the virtual police registration allowing citizens to ask for virtual permission to go out during quarantines. While Chile is substantively ahead of regional digital government performance, it must continue to strive for excellence in its transformation efforts. The uptake of digital government services remains comparatively low in Chile, albeit it has increased significantly, confirming the momentum initiated a decade ago in this area (Figure 34).Significant potential remains in Chile for a wider uptake of digital government services. Chile's ongoing implementation of the Digital Transformation of the State Law (Ley de Transformación Digital) (MINSEGPRES, 2019) promises to digitalise interactions between Chileans and the government. The simplification and elimination of unnecessary procedures, the greater interoperability of State institutions in requesting information as well as the complete digitalisation of their internal processes, are proposed steps that offer opportunities to increase access to quality of public services in Chile. Further digitalisation of ChileAtiende, a crossgovernmental one-stop-shop providing public services would reduce the burden and cost of interactions between citizens and the state whilst increasing satisfaction, effectiveness and trust (OECD, 2020[90]). Moreover, the creation of a single digital identity would also improve the quality of services in online 
procedures and eliminate the need for citizens to have different keys to complete a single procedure (OECD, 2019[91]).

Data is a strategic asset towards a data-driven public sector. Chilean authorities have put emphasis in strengthening interoperability and promoting digital integration of the public sector to facilitate data sharing and integrated service delivery in the public administration. Continuous and stronger efforts to improve data governance and management in the country's public sector would help it prepare for the advent of increasingly sophisticated data-processing capabilities, such as artificial intelligence (OECD, 2019[91]). Developing a comprehensive strategy and/or policy for public sector data and its chain value would be key (OECD, 2019[91]). This involves: i) establishing an authority responsible for developing and co-ordinating an overall strategy for public sector data, ii) identifying key data assets and gaps, iii) establish standards for data management, iv) strengthening the overall data value chain for the public sector, v) dupporting the identification of public sector data assets, registries and interoperability nodes, and help conceive their governance and data sharing architecture to protect sensitive data, vi) ensuring the highest standards in terms of data security and privacy in public sector operations and make public sector data open by default.

\section{Figure 34. The uptake of digital government services remains low}

Individuals who used the Internet to interact with public authorities, as a percentage of individuals, 2018

$\%$

100

80

60

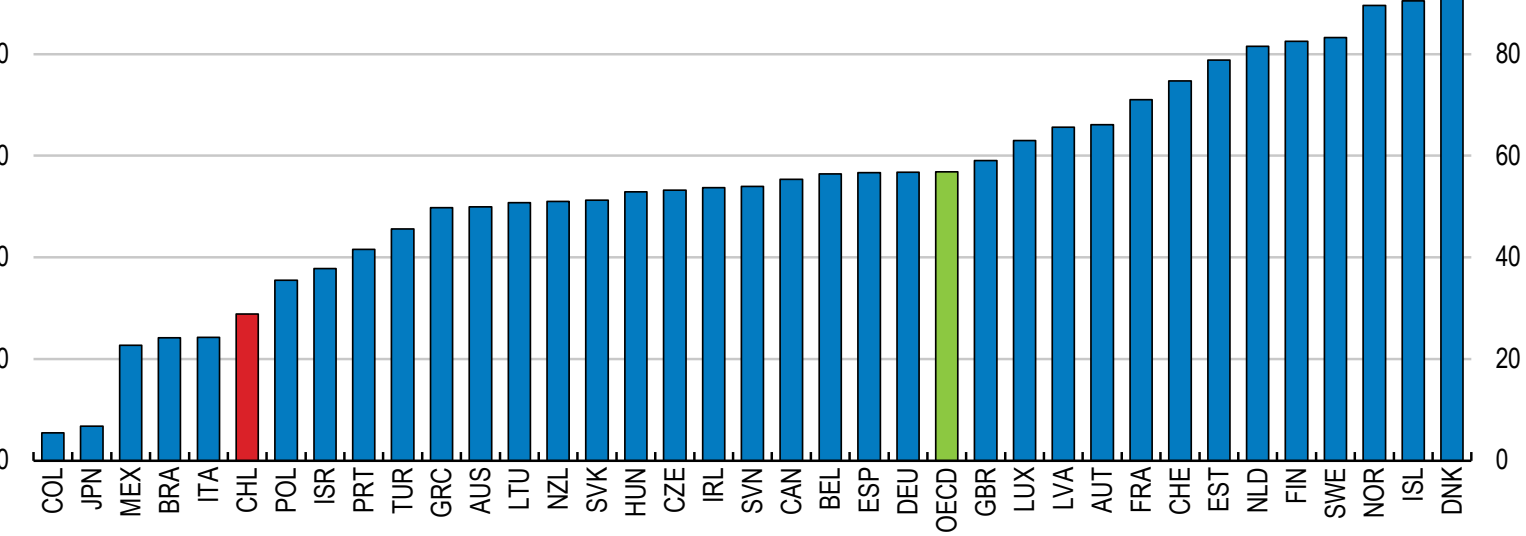

Note: For Chile, data refer to 2017. OECD refers to an unweighted average.

Source: OECD, ICT Access and Usage by Households and Individuals Database, http://oe.cd/hhind, December 2018.

StatLink 젶ㄴ https://doi.org/10.1787/888934194371

\section{Digital security capacity must be stepped-up}

Rapid digitisation and network connectivity in Chile are creating new challenges for the protection of sensitive data and network communications, affecting the trust of businesses and individuals in online activities and entailing some potential disruption of economic and social activities by digital security incidents. Such incidents can negatively impact the activities of all businesses, both SMEs and larger firms, governments and individuals, and generate financial and reputational harm. The 2018 digital security attack on Bank of Chile, where hackers siphoned USD 10 million of funds by releasing fake fraudulent transactions, puts into question digital security regulations in Chile, which have not been updated since 1993. This also highlights the necessity of significant actions in this area, given that the risk of digital security incidents grows as digital transformation deepens. Currently, Chile stands as one of the OECD countries with the lowest digital security capacity (Figure 35 ). 
One important challenge of digital transformation is the increasing role taken on by smaller actors such as SMEs, which extends digital security risks beyond the realm of large central players such as banks or electricity companies. Such SMEs include start-ups offering innovative payment systems or block chainbased technologies. Besides start-ups, well-established SMEs are often the weakest link in larger firms' value chains. Therefore targeting them to manage digital security risks is important for direct consequences but also indirect through impact to larger firms. Public policies can foster digital security by creating the conditions for these firms to better manage digital security risks, and for individuals to better understand risks and use digital devices more responsibly. Chile recently took steps in that direction with the 2022 Cybersecurity plan, which aims at establishing a robust and resilient information infrastructure, prepared to face and recover from digital security incidents on the basis of a risk management approach. The plan also seeks to promote a cybersecurity culture at all levels of society with the purpose of making the tools and knowledge available better understand the benefits and challenges of using digital technologies, and appropriately manage the risks.

\section{Figure 35. Cybersecurity capacities are lacking}

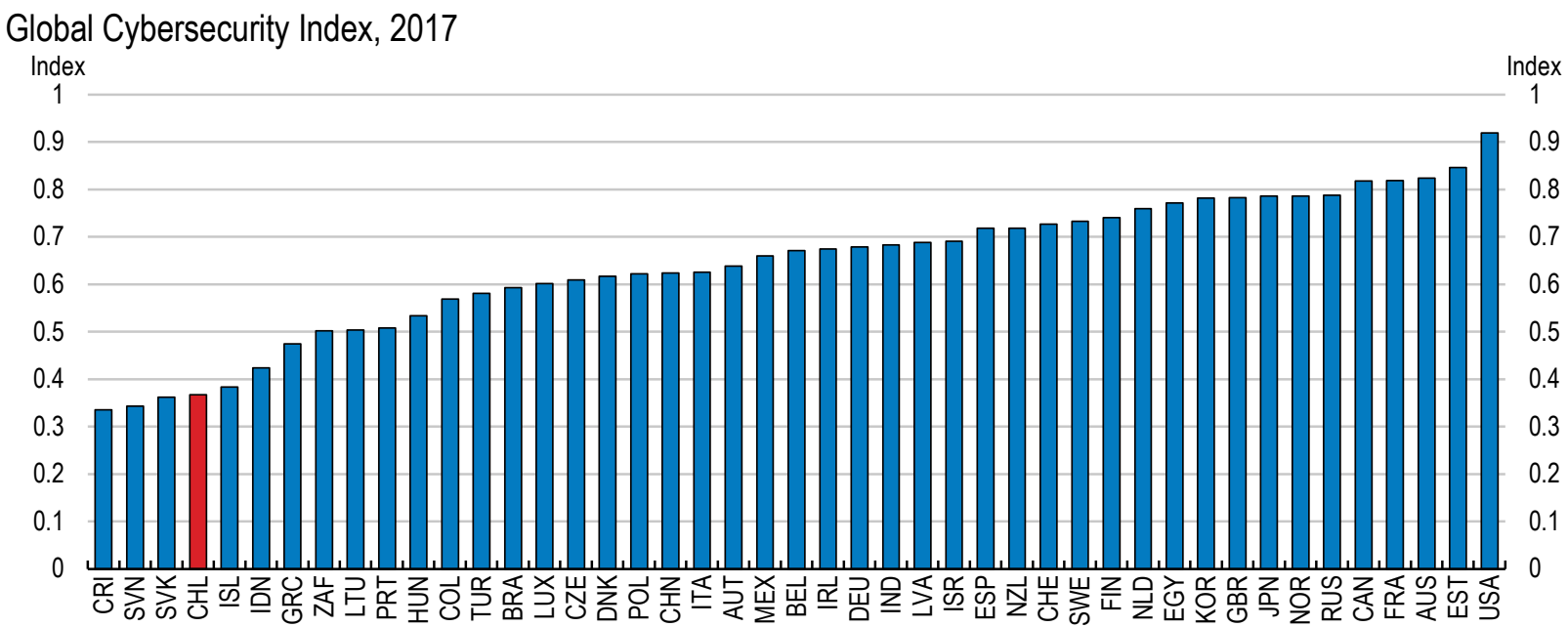

Note: The Global Cybersecurity Index (GCl) is computed on the basis of the following pillars: legal (legal institutions and frameworks dealing with cybersecurity and cybercrime); technical (technical institutions and frameworks dealing with cybersecurity); organisational (policy coordination institutions and strategies for cybersecurity development at the national level); capacity building (existence of research and development, education and training programmes, and certified professionals and public sector agencies fostering capacity building) and cooperation (refers to partnerships, co-operative frameworks and information-sharing networks).

Source: ITU (2017), Global Cybersecurity Index, Geneva. https://www.itu.int/en//TU-D/Cybersecurity/Pages/global-cybersecurity-index.aspx.

StatLink הताst https://doi.org/10.1787/888934194390

Promoting a cybersecurity culture is essential to develop common grounds across the society about how to manage risk in a manner that does not reduce the economic and social opportunities of using digital technologies. This will notably present many challenges to Chile's educational system. Early and advanced education of the Chilean population should be a part of these challenges: digital gaps generated by inequitable access to resources, skills, infrastructure and connectivity should be addressed to create a common digital security culture.

\section{Establish an interoperable privacy framework}

As digital transformation gains momentum, privacy, the protection of personal data in particular, is emerging as a critical issue. With the ongoing deployment of high-speed broadband and $5 \mathrm{G}$ networks, personal data will be increasingly collected and will come to play an increasingly important role in the 
economy and the everyday lives of Chileans. This can potentially yield great societal and economic benefits. At the same time, this will increase the risks to individuals' privacy. Chile has the highest reported rates of privacy violation in all OECD countries (Figure 36). These violations implicate not only the individuals concerned, but also the core values and principles which privacy and personal data protection seek to promote, including individual autonomy, equality and free speech, which may have a broader impact on society as a whole.

Privacy is not only a recognised fundamental value that merits protection, but a condition for the free flow of personal data across organisations and borders, and with it data-driven innovation, economic growth and social prosperity (OECD, 2019 $\left.{ }_{[4]}\right)$. In 1999, Chile became the first South American country to pass a comprehensive data privacy law. It has been amended since, with the addition of personal data protection in the Chilean Constitution in 2018. This new legal framework is a welcome step to confront forthcoming challenges. It enacts a new basis for the legal processing of personal data, establishes the duties of information, transparency and the duty to report security breaches to the authorities and, in certain serious cases, to data subjects. It also regulates the sharing of data with third parties. However, in several areas the legal framework can be strengthened further, as some of its elements are partially defined while others are simply missing. For example, the notion of data breach is not defined, which makes it difficult to state when a privacy violation occurred. Also, the new law does not regulate or establish a Data Protection Officer or similar body in charge of monitoring data privacy and enforcing sanctions if necessary.

\section{Figure 36. Data privacy violations are the highest in the OECD}

Individuals who experienced privacy violations, as a percentage of Internet users, 2015

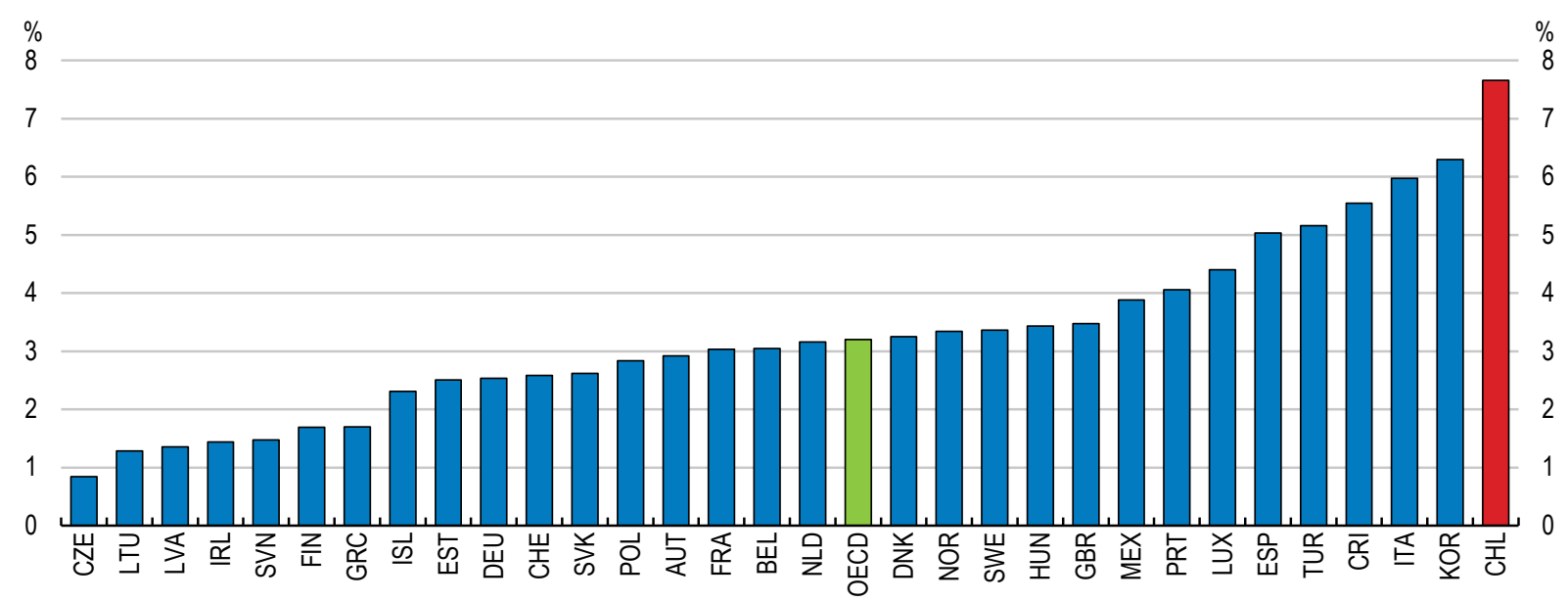

Note: Except otherwise stated, Internet users are defined as individuals who accessed the Internet within the last 12 months. For Chile, data refer to 2014. From 2015 onwards, information was collected through an independent thematic survey, unlike previous years during which information was obtained through a module administered in various surveys. OECD refers to an unweighted average.

Source: OECD (2019), Measuring the Digital Transformation, https://dx.doi.org/10.1787/9789264311992-en, based on OECD, ICT Access and Usage by Households and Individuals database.

It will be important for Chile to foster the interoperability of its data protection regulations with those in other countries, and in particular its key trading partners. This will help to enhance trade. Finally, interoperability provisions should be established. Currently, the law does not set forth specific requirements or restrictions on transfers of personal data abroad. As a result, when Chilean firms receive data from the European Union, they have to be compliant with the standards established by the EU legislation, as well as the Chilean one for Chilean subjects, which is costly and complex. However, while countries apply different 
privacy frameworks, they are nonetheless largely pursuing the same goals, and frequently use similar approaches, as demonstrated by agreement on high-level guiding principles and good practices or legislation (OECD, 2019[4]]). The European Union's General Data Protection Regulation (GDPR), which harmonises data protection laws of all countries in the European Economic Area, is a practical example of how privacy rules can work for countries that do not recognise each other's data protection laws. It includes mechanisms for multinational enterprises to implement "binding corporate rules" on all affiliates to enable transfers of data between them, even if the sub-entities are based in countries that have not forged a specific mechanism or agreement. For Chile, in the context of the Asia-Pacific Economic Cooperation (APEC) organisation, the enforceable system of Cross-Border Privacy Rules (CBPR), through which participating APEC economies work to lift the overall standard of privacy across the region, should be pushed further to establish clear interoperability of data. 


\begin{tabular}{|c|c|}
\hline MAIN FINDINGS & RECOMMENDATIONS (Key recommendations are bolded) \\
\hline \multicolumn{2}{|c|}{ Unlocking digital skills and the innovation capacity } \\
\hline $\begin{array}{l}\text { Fixed broadband penetration is low by OECD standards and } \\
\text { rural/urban disparities are large. Entry barriers in the } \\
\text { communication sector are high. }\end{array}$ & $\begin{array}{l}\text { Ensure low barriers to entry to the communication sector by replacing the } \\
\text { existing regulation for concessions. }\end{array}$ \\
\hline $\begin{array}{l}\text { Individuals and workers in Chile often lack the foundation and } \\
\text { digital skills necessary to flourish in a digital world. }\end{array}$ & $\begin{array}{l}\text { Continue to improve quality of general education from early years. } \\
\text { Increase digital literacy in schools giving digital skills more prominence } \\
\text { in the national curriculum, and enhancing the digital skills of teachers and } \\
\text { school-directors. }\end{array}$ \\
\hline The country faces a clear shortage of ICT professionals. & $\begin{array}{l}\text { Promote ICT programmes for the high-skilled jobs involving the private sector } \\
\text { in the design of curricula and needs. }\end{array}$ \\
\hline $\begin{array}{l}\text { An overwhelming majority of ICT specialists are men, reflecting } \\
\text { early educational choices. }\end{array}$ & $\begin{array}{l}\text { Increase girls' interest in digital skills by targeting mandatory ICT classes and } \\
\text { voluntary ICT hobby activities towards girls from the early stages of compulsory } \\
\text { schooling. }\end{array}$ \\
\hline $\begin{array}{l}\text { A large share of Internet users are either unaware of or passive } \\
\text { towards IT security and privacy issues. }\end{array}$ & $\begin{array}{l}\text { Integrate digital security and awareness throughout the educational system and } \\
\text { in adult education activities related to digital skills. }\end{array}$ \\
\hline $\begin{array}{l}\text { R\&D and innovation expenditure is low, especially in SMEs, and } \\
\text { comes mainly from public resources. }\end{array}$ & $\begin{array}{l}\text { Foster a collaborative digital innovation ecosystem by strengthening } \\
\text { business collaboration and fostering open-innovation practices. }\end{array}$ \\
\hline $\begin{array}{l}\text { Services innovation is key to lead digital transformation, but they } \\
\text { face several barriers for development. }\end{array}$ & $\begin{array}{l}\text { Revise existing support initiatives that exclude services innovation, and design } \\
\text { new-targeted programmes if needed. }\end{array}$ \\
\hline \multicolumn{2}{|c|}{ Boosting business dynamism and the diffusion of knowledge } \\
\hline $\begin{array}{l}\text { Adoption of digital tools lags behind other OECD countries, } \\
\text { particularly for SMEs. }\end{array}$ & $\begin{array}{l}\text { Boost public support to SMEs, in cooperation with the private sector, } \\
\text { trough targeted programmes to facilitate the adoption digital tools. }\end{array}$ \\
\hline $\begin{array}{l}\text { Low competition in the payment system could have hampered } \\
\text { the Fintech sector development. }\end{array}$ & $\begin{array}{l}\text { Monitor closely the competition in the financial and electronic payment sector } \\
\text { and take further actions if needed. }\end{array}$ \\
\hline $\begin{array}{l}\text { One the most important barriers to start-ups to emerge and grow } \\
\text { is lack of financing. }\end{array}$ & $\begin{array}{l}\text { Promote further the development of the Fintech sector, venture capital, angel } \\
\text { investors and alternative financing for start-ups and SMEs. }\end{array}$ \\
\hline $\begin{array}{l}\text { Digital services are key to lead digital transformation, but they } \\
\text { face several barriers for development. }\end{array}$ & $\begin{array}{l}\text { Implement international standards for electronic contracts for cross-border } \\
\text { transactions. }\end{array}$ \\
\hline $\begin{array}{l}\text { The digital economy poses new challenges for competition } \\
\text { policy. }\end{array}$ & $\begin{array}{l}\text { Systematically review the competitive pressures on digital sectors by } \\
\text { conducting market studies and applying the guidelines of the OECD's } \\
\text { Competition Assessment Toolkit. }\end{array}$ \\
\hline \multicolumn{2}{|c|}{ Preserving social cohesion and helping workers make the most out of a dynamic labour market } \\
\hline $\begin{array}{l}\% 50 \text { of jobs are at risk of automation. The low and middle- } \\
\text { income classes particularly affected by automation risks. } \\
\text { Vulnerable workers have the lower access to training courses. }\end{array}$ & $\begin{array}{l}\text { Embark in a full revision of firm-provided training programmes (tax credit) } \\
\text { to increase relevance and quality of training and better target participation } \\
\text { to vulnerable workers. }\end{array}$ \\
\hline $\begin{array}{l}\text { Training programmes lack most of the times sufficient relevance } \\
\text { and quality. }\end{array}$ & $\begin{array}{l}\text { Better align training courses with labour market needs by collaborating more } \\
\text { with the private sector and conducting national skills anticipation and } \\
\text { assessment exercises. }\end{array}$ \\
\hline Most self-employed do not contribute to the pension system. & $\begin{array}{l}\text { Increase incentives so that self-employed contribute to the pension system and } \\
\text { raise awareness of its importance. }\end{array}$ \\
\hline The coverage and levels of unemployment benefits are low. & $\begin{array}{l}\text { Make the temporary measures to increase protection for unemployed workers } \\
\text { permanent or automatically triggered when unemployment reaches certain } \\
\text { thresholds. }\end{array}$ \\
\hline Informality is high by OECD standards. & $\begin{array}{l}\text { Expand the existing wage subsidies in formal jobs for young and low-wage } \\
\text { workers. }\end{array}$ \\
\hline \multicolumn{2}{|c|}{ Achieving sustainable and reliable digital infrastructures } \\
\hline $\begin{array}{l}\text { The legal framework on privacy is weak and hampers digital } \\
\text { engagement. }\end{array}$ & Establish clear interoperability provisions for personal data. \\
\hline $\begin{array}{l}\text { Digital security is lagging behind while the emergence of new } \\
\text { types of threats can have a significant impact on financial } \\
\text { stability. }\end{array}$ & $\begin{array}{l}\text { Step-up investment in digital security and promote information across the } \\
\text { society about how to manage risk. }\end{array}$ \\
\hline
\end{tabular}




\section{References}

Alaimo, V., M. Chaves and N. Soler (2019), El futuro del trabajo en América Latina y el Caribe: ¿Cómo garantizar los derechos de los trabajadores en la era digital? (versión para imprimir), Inter-American Development Bank, http://dx.doi.org/10.18235/0002088.

Albagli, E. et al. (2019), "Firm productivity dynamics and distribution: Evidence for Chile using micro data from administrative tax records", Working Papers, No. 831, Central Bank of Chile, https://ideas.repec.org/p/chb/bcchwp/831.html.

Almeida, R., L. Orr and D. Robalino (2014), "Wage subsidies in developing countries as a tool to build human capital: design and implementation issues", IZA Journal of Labor Policy, Vol. 3/1, p. 12, http://dx.doi.org/10.1186/2193-9004-3-12.

Alonso Soto, D. (2020), "Technology and the future of work in emerging economies: What is different", OECD Social, Employment and Migration Working Papers, No. 236, OECD Publishing, Paris, https://dx.doi.org/10.1787/55354f8f-en.

Alonso Soto, D. (2019), "Technology and the future of work in emerging economies: What is different?", Social, Employment and Migration Working Papers, OECD, https://www.oecdilibrary.org/social-issues-migration-health/oecd-social-employment-and-migration-workingpapers 1815199x.

Alvarez, R., A. Zahler and C. Bravo (2013), "Innovation and productivity in services: evidence from Chile", Documentos de Trabajo, Universidad de Chile, Facultad de Economía y Negocios, http://repositorio.uchile.cl/handle/2250/122756.

Amaral, N. et al. (2019), El futuro del trabajo en América Latina y el Caribe: ¿Cuáles son las ocupaciones y las habilidades emergentes más demandadas en la región? (versión interactiva), Inter-American Development Bank, Washington, D.C., http://dx.doi.org/10.18235/0001677.

Andrews, D., G. Nicoletti and C. Timiliotis (2018), "Digital technology diffusion: A matter of capabilities, incentives or both?", OECD Economics Department Working Papers, No. 1479, OECD Publishing, Paris, https://ideas.repec.org/p/oec/ecoaaa/1476-en.html.

Bajgar, M. et al. (2019), "Industry Concentration in Europe and North America", OECD Productivity Working Papers, No. 18, OECD Publishing, Paris, https://dx.doi.org/10.1787/2ff98246-en.

Bajgar, M., C. Criscuolo and J. Timmis (2019), "Mergers and Acquisitions, Concentration and Productivity: What Do We Know So Far?", OECD Productivity Papers, No. forthcoming, OECD Publishing, Paris.

Bravo, D. and T. Rau (2013), Effects of Large-scale Youth Employment Subsidies: Evidence from a Regression Discontinuity Design.

Bravo, J., A. García and H. Schlechter (2019), "Mercado Laboral Chileno para la Cuarta Revolución Industrial - Clapes UC", Documentos de Trabajo, No. 59, Clapes, Santiago de Chile, http://www.clapesuc.cl/investigaciones/doc-trabajo-no59-mercado-laboral-chileno-parala-cuarta-revolucion-industrial/. 
Calligaris, S., C. Criscuolo and L. Marcolin (2018), "Mark-ups in the digital era", OECD Publishing, http://dx.doi.org/10.1787/4efe2d25-en.

Casalini, F., J. López González and E. Moïsé (2019), "Approaches to market openness in the digital age", OECD Trade Policy Papers, No. 219, OECD Publishing, Paris, https://dx.doi.org/10.1787/818a7498-en.

Centro de Microdatos (2012), Evaluación de Impacto del Programa de Subsidio al Empleo Joven, Universidad de Chile.

CNP (2019), Calidad Regulatoria en Chile: Una Revisión de Sectores Estratégicos - Comisión Nacional de Productividad, Comisión Nacional de Productividad, https://www.comisiondeproductividad.cl/estudios/finalizados/revision-de-sectoresestrategicos/.

CNP (2019), Informe anual de productividad 2018, Comisión Nacional de Productividad, https://www.comisiondeproductividad.cl/estudios/finalizados/estudio-informe-anual-deproductividad-2018/.

CNP (2018), Formación de Competencias para el Trabajo en Chile, Comisión Nacional de Productividad, Santiago de Chile, https://www.comisiondeproductividad.cl/estudios/formacion-de-competencias-para-el-trabajoen-chile/.

Espinoza, R. and L. Reznikova (2020), "Who can log in? The importance of skills for the feasibility of teleworking arrangements across OECD countries", OECD Social, Employment and Migration Working Papers, No. 242, OECD Publishing, Paris, https://dx.doi.org/10.1787/3f115a10-en.

Felten, E., M. Raj and R. Seamans (2019), "The Occupational Impact of Artificial Intelligence: Labor, Skills, and Polarization", SSRN Electronic Journal, http://dx.doi.org/10.2139/ssrn.3368605.

Ferencz, J. and F. Gonzales (2019), "Barriers to trade in digitally enabled services in the G20", OECD Trade Policy Papers, No. 232, OECD Publishing, Paris, https://dx.doi.org/10.1787/264c4c02-en.

FIAP (2018), El rol de la tecnología y la economía del comportamiento para incrementar el ahorro previsional: experiencias recientes en Chile, Colombia, México y Perú.

Finnovista (2019), El ecosistema Fintech en Chile crece un 49\% en los últimos 18 meses y se consolida como el más maduro en la región latinoamericana, https://www.finnovista.com/elecosistema-fintech-en-chile-crece-un-49-en-los-ultimos-18-meses-y-se-consolida-como-elmas-maduro-en-la-region-latinoamericana/ (accessed on 11 October 2019).

FinteChile and EY (2019), Primer estudio fintech en Chile: Desafíos y oportunidades, https://www.mundialis.cl/public/uploads/noticias/fintech-report-chile-digital.pdf.

FNE (2019), Estudio de Mercado sobre Notarios, Fiscalia Nacional Economica, Santiago de Chile, https://www.fne.gob.cl/.

Grundke, R. et al. (2018), "Which skills for the digital era?: Returns to skills analysis", OECD Science, Technology and Industry Working Papers, No. 2018/09, OECD Publishing, Paris, https://dx.doi.org/10.1787/9a9479b5-en. 
Guellec, D. and C. Paunov (2018), "Innovation policies in the digital age", OECD Science, Technology and Industry Policy Papers, No. 59, OECD Publishing, Paris, https://dx.doi.org/10.1787/eadd1094-en.

Hartley, G., J. van Ours and M. Vodopivec (2011), "Incentive effects of unemployment insurance savings accounts: Evidence from Chile”, Labour Economics, Vol. 18/6, pp. 798-809, http://dx.doi.org/10.1016/J.LABECO.2011.06.011.

Hitschfeld, M., P. Garda and N. Ruiz (forthcoming), "Digital adoption and productivity dispersion: Evidence from Chile", Economics Department Working Papers, OECD.

Huneeus, C., S. Leiva and A. Micco (2012), "Unemployment Insurance and Search Effort in Chile", SSRN Electronic Journal, http://dx.doi.org/10.2139/ssrn.2149060.

IDB (2015), Jobs for Growth.

IDC (2016), Networking Skills in Latin America, IDC Analyse the FUture, https://www.cisco.com/c/dam/assets/csr/pdf/IDC Skills Gap - LatAm.pdf.

INTAL (2020), América Latina en movimiento, https://publications.iadb.org/publications/spanish/document/Am\%C3\%A9rica Latina en movi miento Competencias y habilidades en la Cuarta Revoluci\%C3\%B3n Industrial es.pdf.

Intelis (2017), Estudio de evaluación de la ley de incentivo tributario a la inversión en $1+D$, https://www.economia.gob.cl/wp-content/uploads/2017/04//nforme-final-Evaluaci\%C3\%B3nLey-ID.pdf.

ITU (2020), Measuring Digital Development: ICT Price Trends 2019, https://www.itu.int/en/ITUD/Statistics/Pages/ICTprices/default.aspx.

Kässi, O. and V. Lehdonvirta (2018), "Online labour index: Measuring the online gig economy for policy and research", Technological Forecasting and Social Change, Vol. 137, pp. 241-248, http://dx.doi.org/10.1016/J.TECHFORE.2018.07.056.

Koreen, M., A. Laboul and N. Smaini (2018), "G20/OECD Effective Approaches for Implementing the G20/OECD High-Level Principles on SME Financing", OECD SME and Entrepreneurship Papers, No. 9, OECD Publishing, Paris, https://dx.doi.org/10.1787/329168b6-en.

Larrañaga (2011), Informe final comisión revisora del sistema de capacitación e intermediación laboral, report of a commission of experts of the Ministery of Labour and Social Welfare, https://www.cl.undp.org/content/chile/es/home/library/poverty/informes de comisiones/inform e-final-comision-revisora-del-sistema-de-capacitacion-e-in.html.

LAVCA (2017), 2017 Trend Watch: Latin American Venture Capital, https://lavca.org/industrydata/trend-watch-2016-latin-american-venture-capital/.

LinkedIn (2016), Will This Year's College Grads Job-Hop More Than Previous Grads, Official Linkedln Blog, https://blog.linkedin.com/2016/04/12/will-this-year s-college-grads-job-hopmore-than-previous-grads.

López González, J. and J. Ferencz (2018), "Digital Trade and Market Openness”, OECD Trade Policy Papers, No. 217, OECD Publishing, Paris, https://dx.doi.org/10.1787/1bd89c9a-en. 
López González, J. and M. Jouanjean (2017), "Digital Trade: Developing a Framework for Analysis", OECD Trade Policy Papers, No. 205, OECD Publishing, Paris, https://dx.doi.org/10.1787/524c8c83-en.

Marköö, C. and P. Garda (forthcoming), "Is the impact of new digital technologies already visible in the Chilean labour market?", Economics Department Working Papers, OECD, Paris.

MEFT (2019), Encuesta sobre Gasto y Personal en I+D año 2017, https://www.economia.gob.cl/wp-content/uploads/2019/02/Presentaci\%C3\%B3n-resultadosencuesta-de-ID-a\%C3\%B10-2017.pdf.

Ministry of Labour (2017), Informalidad laboral: más trabajadores productivos sin protección laboral, Departamento de Estudios de la Dirección del Trabajo, Ministry of Labour and Social Welfare.

Mostafa, T. (2019), "Why don't more girls choose to pursue a science career?", PISA in Focus, No. 93, OECD Publishing, Paris, https://dx.doi.org/10.1787/02bd2b68-en.

Nedelkoska, L. and G. Quintini (2018), "Automation, skills use and training”, OECD Social, Employment and Migration Working Papers, No. 202, OECD Publishing, Paris, https://dx.doi.org/10.1787/2e2f4eea-en.

OECD (2021), Enhancing economic and social outcomes in Chile: Improving the telecommunication sector. Assessment and policy actions., OECD.

OECD (2021), OECD Economic Surveys: Chile 2021, OECD Publishing, Paris, https://dx.doi.org/10.1787/79b39420-en.

OECD (2020), Digital Government in Chile - Improving Public Service Design and Delivery, OECD Digital Government Studies, OECD Publishing, Paris, https://dx.doi.org/10.1787/b94582e8-en.

OECD (2020), Financing SMEs and Entrepreneurs 2020: An OECD Scoreboard, OECD Publishing, Paris, https://dx.doi.org/10.1787/061fe03d-en.

OECD (2020), "Going Digital integrated policy framework", OECD Digital Economy Papers, No. 292, OECD Publishing, Paris, https://dx.doi.org/10.1787/dc930adc-en.

OECD (2020), "OECD Reviews of Digital Transformation: Going Digital in Brazil”.

OECD (2020), School education during COVID-19: Were teachers and students ready? Chile country note, http://www.oecd.org/education/Chile-coronavirus-education-country-note.pdf.

OECD (2019), Adult Learning in Italy: What Role for Training Funds ?, Getting Skills Right, OECD Publishing, Paris, https://dx.doi.org/10.1787/9789264311978-en.

OECD (2019), Digital Government in Chile - A Strategy to Enable Digital Transformation, OECD Digital Government Studies, OECD Publishing, Paris, https://dx.doi.org/10.1787/f77157e4-en.

OECD (2019), Digital Government in Chile - Digital Identity, OECD Digital Government Studies, OECD Publishing, Paris, https://dx.doi.org/10.1787/9ecba35e-en.

OECD (2019), Digital Innovation: Seizing Policy Opportunities, OECD Publishing, Paris, https://dx.doi.org/10.1787/a298dc87-en. 
OECD (2019), Financing SMEs and Entrepreneurs 2019: An OECD Scoreboard, OECD

Publishing, Paris, https://dx.doi.org/10.1787/fin sme ent-2019-en.

OECD (2019), Getting Skills Right: Future-Ready Adult Learning Systems, Getting Skills Right, OECD Publishing, Paris, https://dx.doi.org/10.1787/9789264311756-en.

OECD (2019), Going Digital: Shaping Policies, Improving Lives, OECD Publishing, Paris, https://dx.doi.org/10.1787/9789264312012-en.

OECD (2019), Individual Learning Accounts : Panacea or Pandora's Box?, OECD Publishing, Paris, https://dx.doi.org/10.1787/203b21a8-en.

OECD (2019), Key Issues Paper For the Meeting of the OECD Council at Ministerial Level, OECD Publishing, Paris, http://www.oecd.org/mcm/documents/KIP\%20\%20CMIN(2019)2\%20-\%20EN\%20.pdf.

OECD (2019), OECD Employment Outlook 2019: The Future of Work, OECD Publishing, Paris, https://dx.doi.org/10.1787/9ee00155-en.

OECD (2019), OECD Reviews of Digital Transformation: Going Digital in Colombia, OECD Publishing, Paris, https://dx.doi.org/10.1787/781185b1-en.

OECD (2019), OECD Skills Outlook 2019 : Thriving in a Digital World, OECD Publishing, Paris, https://dx.doi.org/10.1787/df80bc12-en.

OECD (2019), Pensions at a Glance 2019: OECD and G20 Indicators, OECD Publishing, Paris, https://dx.doi.org/10.1787/b6d3dcfc-en.

OECD (2018), Considering non-price effects in merger control Background note by the Secretariat, OECD Publishing, Paris, https://one.oecd.org/document/DAF/COMP(2018)2/en/pdf.

OECD (2018), OECD Economic Surveys: Chile 2018, OECD Publishing, Paris, https://dx.doi.org/10.1787/eco surveys-chl-2018-en.

OECD (2018), The Future of Social Protection: What Works for Non-standard Workers?, OECD Publishing, Paris, https://dx.doi.org/10.1787/9789264306943-en.

OECD (2018), Which skills for the digital era?: Returns to skills analysis, OECD Publishing, Paris, https://doi.org/10.1787/18151965.

OECD (2017), Algorithms and Collusion: Competition Policy in the Digital Age, http://www.oecd.org/daf/competition/Algorithms-and-colllusion-competition-policy-in-thedigital-age.pdf.

OECD (2017), OECD Science, Technology and Industry Scoreboard 2017: The digital transformation, OECD Publishing, Paris, https://dx.doi.org/10.1787/9789264268821-en.

OECD (2016), Skills for a Digital World, OECD Publishing, Paris, http://www.oecd.org/employment/emp/Skills-for-a-Digital-World.pdf.

OECD (2016), Start-up Latin America 2016: Building an Innovative Future, Development Centre Studies, OECD Publishing, Paris, https://dx.doi.org/10.1787/9789264265660-en. 
OECD (2015), Students, Computers and Learning: Making the Connection, PISA, OECD

Publishing, Paris, https://dx.doi.org/10.1787/9789264239555-en.

OECD/G20 (2015), Progress Report on G20/OECD High Level Principles on SME Financing, OECD, https://www.oecd.org/finance/private-pensions/G20-OECD-High-level-Principles-onSME-Financing-Progress-Report.pdf.

OECD/IDB (2016), Broadband Policies for Latin America and the Caribbean: A Digital Economy Toolkit, OECD Publishing, Paris, https://dx.doi.org/10.1787/9789264251823-en.

OECD/UN (2018), Production Transformation Policy Review of Chile: Reaping the Benefits of New Frontiers, OECD Development Pathways, OECD Publishing, Paris, https://dx.doi.org/10.1787/9789264288379-en.

Perticara, M. and P. Celhay (2010), Informalidad Laboral y Políticas Públicas en Chile, Universidad Alberto Hurtado, http://190.98.232.97/bitstream/handle/11242/6678/l257Perticara-y-Celhay-informalidad.pdf? sequence=1\&isAllowed $=y$.

Rodriguez, J. and S. Urzúa (2012), An Evaluation of Training Programs Financed by Public Funds in Chile, manuscript.

Saia, A., D. Andrews and S. Albrizio (2015), "Productivity Spillovers from the Global Frontier and Public Policy: Industry-Level Evidence", OECD Economics Department Working Papers, No. 1238, OECD Publishing, Paris, https://dx.doi.org/10.1787/5js03hkvxhmr-en.

Sehnbruch, K., R. Carranza and J. Prieto (2019), "The Political Economy of Unemployment Insurance based on Individual Savings Accounts: Lessons from Chile", Development and Change, Vol. 50/4, pp. 948-975, http://dx.doi.org/10.1111/dech.12457.

Sepulveda, J., M. Alfaro and E. Vasquez (2014), "Management of innovation in Chile: a case study for enhancing innovation capability of SMEs", Journal of Innovation Economics, Vol. 13/1, p. 115, http://dx.doi.org/10.3917/jie.013.0115.

Sorbe, S. et al. (2019), "Digital Dividend: Policies to Harness the Productivity Potential of Digital Technologies", OECD Economic Policy Papers, No. 26, OECD Publishing, Paris, https://dx.doi.org/10.1787/273176bc-en.

Subtel (2017), IX Encuesta de Acceso y Usos de Internet, https://www.subtel.gob.cl/wpcontent/uploads/2018/07/Informe Final IX Encuesta Acceso y Usos Internet 2017.pdf.

Suominen, K. (2017), Accelerating Digital Trade in Latin America and the Caribbean, InterAmerican Development Bank, Washington, D.C., http://dx.doi.org/10.18235/0000636.

WEF (2018), The Future of Jobs Report, World Economic Forum, http://www3.weforum.org/docs/WEF Future of Jobs 2018.pdf.

Weller, J., S. Gontero and S. Campbell (2019), Cambio tecnológico y empleo: una perspectiva latinoamericana. Riesgos de la sustitución tecnológica del trabajo humano y desafíos de la generación de nuevos puestos de trabajo, https://repositorio.cepal.org/handle/11362/44637.

WTO (2018), "World Trade Report: The future of world trade: How digital technologies are transforming global commerce", World Trade Organization, Paris, https://www.wto.org/english/res e/publications e/world trade report18 e.pdf. 
66 | ECO/WKP(2021)35

Zahler, A., D. Goya and M. Caamanio (2018), Obstacles to innovation in Chile, https://editorialexpress.com/cgi-

bin/conference/download.cgi?db name=SECHI2018\&paper id=17. 